\title{
Structural Geology \\ of the Hawthorne \\ and Tonopah \\ Quadrangles, Nevada
}

$B y$ HENRY G. FERGUSON and SIEMON W. MULLER

GEOLOGICAL SURVEY PROFESSIONAL PAPER 216

A study of the geology of pre-Tertiary rocks and Jurassic diastrophism

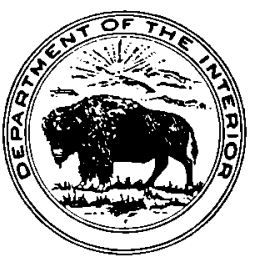

UNITED STATES GOVERNMENT PRINTING OFFICE, WASHINGTON : 1949 
UNITED STATES DEPARTMENT OF THE INTERIOR

J. A. Krug, Secretary

GEOLOGICAL SURVEY

W. E. Wrather, Director

For sale by the Superintendent of Documents, U. S. Government Printing Office Washington 25, D. C. - Price $\$ 2.00$ (paper cover) 


\section{CONTENTS}

Abstract

Introduction . . . Location

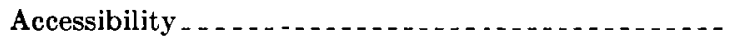
Previous investigations . . . . . . . . . . . . . . Field work and acknowledgments. . . . . . . . .

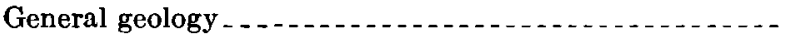

Outline of stratigraphy Distribution of the pre-Tertiary rocks. . . . . . Paleozoic rocks............................. Mesozoic rocks _......... Triassic system ........................ Candelaria formation (Lower Triassic) Grantsville formation (Middle Triassic) Excelsior formation (Middle Triassic) -Luning formation (Upper Triassic) .... Gabbs formation (Upper Triassic) .... Jurassic system......................... Sunrise formation (Lower Jurassic) _...Dunlap formation (Lower Jurassic) . . Intrusive rocks (Jurassic ?) -............. Tertiary rocks.......... Diastrophic history

Pre-Jurassic deformation......................

Pre-Permian folding..................... Unconformity at base of Lower Triassic . Unconformity at base of Middle Triassic. -Pre-Upper Triassic folding .............. Development of the Luning Embayment.-Jurassic orogeny

Sequence of events

Early Jurassic warping and Dunlap sedimentation ..................

Localized folding and thrusting and development of structural troughs . -

Folding and thrusting in the Luning

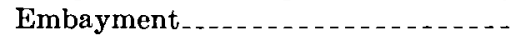

Large-scale thrusting -..............

Deformation of the marginal Paleozoic rocks

Other faults

Intrusion of granitic rocks . . . . . . . .

Date of diastrophism ..........

Post-Jurassic structure.

Thrusting ...................

Flaw in Soda Spring Valley . .

Basin Range faulting......

Areal geology . . . . . . . . . . .

Wassuk Range........ Gillis Range.

Rocks exposed.

Structure. -........

Gillis thrust .......

Tertiary normal faults................

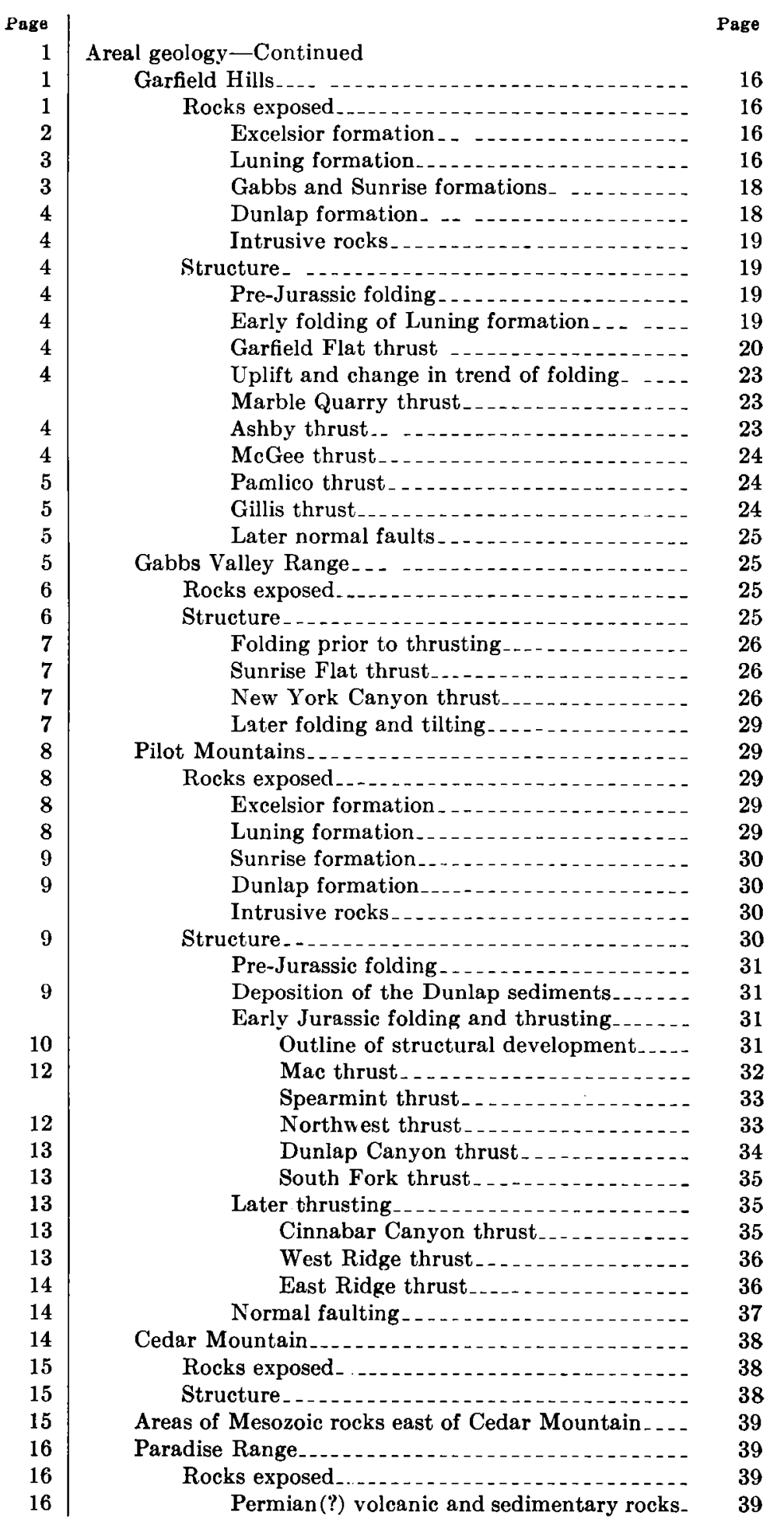
19 3 6

. , 5 25 9 34 35 35 36 6 38 38 
Areal geology-Continued

Paradise Range-Continued

Mesozoic rocks

Luning formation...............

Gabbs and Sunrise formations......

Dunlap formation .................

Intrusive rocks.

Structure $\ldots$

Paradise thrust

South thrust.

Shoshone Mountains ...................

Rocks exposed

Permian(?) rocks.....................

Sedimentary rocks...............

Volcanic rocks.......................

Mesozoic rocks............................

Grantsville formation .............

Luning formation

Gabbs and Sunrise formations

Dunlap formation. ...............

Intrusive rocks

Structure................................

Pre-Jurassic folding . . . . . . . . . . .

Shoshone thrust. . . . . .

Later faulting . . . . . . . . .

Excelsior Mountains

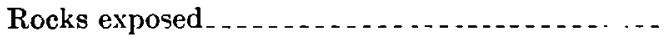

Excelsior formation $\ldots$

Dunlap formation...................

Intrusive rocks

\begin{tabular}{|c|c|}
\hline Page & $\begin{array}{l}\text { Areal geology--Continued } \\
\text { Excelsior Mountains-Continued }\end{array}$ \\
\hline 40 & Strusture \\
\hline 40 & Pre-Jurassic folding \\
\hline 40 & Jurassic folding \\
\hline 40 & Later faulting $\ldots \ldots$ \\
\hline 40 & Miller Mountain and Candelaria Hills $\ldots \ldots \ldots \ldots$ \\
\hline 40 & Rocks exposed \\
\hline 40 & Cambrian sedimentary rocks $\ldots$ \\
\hline 40 & Ordovician sedimentary rocks $\ldots$ \\
\hline 40 & Permian sedimentary rocks $\ldots$ \\
\hline 40 & Candelaria formation \\
\hline 41 & Excelsior(?) formation \\
\hline 41 & Intrusive rocks \\
\hline 41 & Structure \\
\hline 41 & Pre-Permian folding $\ldots \ldots$ \\
\hline 41 & Monte Cristo thrust \\
\hline 41 & Later faulting $\ldots$ \\
\hline 41 & Monte Cristo Range \\
\hline 41 & Rocks exposed \\
\hline 41 & Monte Cristo thrust \\
\hline 41 & Lone Mountain \\
\hline 41 & San Antonio Mountains \\
\hline 42 & Toquima Range. \\
\hline 42 & Rocks exposed \\
\hline 43 & Structure $\ldots$ \\
\hline 44 & Toyabe Range \\
\hline 44 & Rocks exposed \\
\hline 44 & Structure \\
\hline & \\
\hline
\end{tabular}

\section{ILLUSTRATIONS} 2. Geologic map and sections of parts of the Gabbs Valley Range, Garfield Hills, Pilot Mountains, and Excelsior Mountains _ . . . . 3. Diagrammatic sections in northwestern part of Pilot Mountains

4. A, Limestone conglomerate of Dunlap formation, unconformable on limestone of Luning formation; $B$, Coarse fanglomerate of limestone boulders in Dunlap formation, overlying limestone member of Luning formation; $C$, Basal conglomerate of Dunlap formation resting on slate member of Luning formation; $D$, West front of Gabbs Valley

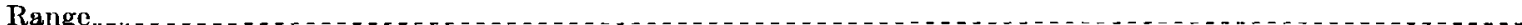

5. Geologic map and sections of area near mouth of New York Canyon, Gabbs Valley Range

6. $A$, "Thrust conglomerate" on ridge south of Sunrise Flat, Gabbs Valley Range; $B$, Interbedded chert with tuffaceous slate and sandstone in Excelsior formation; $C$, Upper part of Mac Canyon showing bend in Mac thrust; $D$, Hill between Mac and Spearmint Canyons, west front of Pilot Mountains

7. Geologic map and sections of northwestern part of Pilot Mountains

8. Isometric projection showing superposed thrust plates and individual formations, northwestern Pilot Mountains_In pocket

9. A, Corrugations in Mac thrust at bend, upper part of Mac Canyon; B, "Thrust conglomerate" in fissures in dolomite of overturned upper plate of Mac thrust; $C$, Brecciated dolomite in upper unit of Luning formation, between Mac and Spearmint thrusts; $D$, North wall of Spearmint Canyon, Pilot Mountains............................

10. $A$, Intricately contorted sandstone of Dunlap formation below Spearmint thrust, Mac Canyon, Pilot Mountains; $B$, Hill north of Mac Canyon showing involute fold; $C, D$, Shoshone thrust

11. Geologic map and sections of part of Paradise Range, Tonopah quadrangle

12. Geologic map and sections of part of Shoshone Mountains, Tonopah quadrangle

13. Geologic map and sections of Shoshone Mountains between Berlin and Grantsvilie

14. Geologic map and sections of part of Gold Range mining district, Excelsior Mountains . . .

15. Geologic map and sections of part of east front of Toyabe Range, between Jett and Pablo Canyons 
Figure 1. Index map showing location of Hawthorne and Tonopah quadrangles.

2. Geologic map and sections of part of Gillis Range, showing outerop of Gillis thrust .

3. Geologic map and sections of area north of Garfield Flat, showing relations of Dunlap formation to Luning and

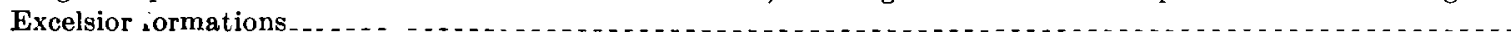

4. Geologic map and sections of a rea east of Garfield Flat, showing outcrop of Garfield Flat thrust $\ldots$

5. Geologic map and sections of area northwest of Garfield Flat, showing relations of Marble Quarry and Garfield Flat thrusts. .

6. Geologic map and sections of aera south of Sunrise Flat, Gabbs Valley Range, showing relation of "thrust conglomerate" to New York Canyon thrust $\ldots \ldots$

7. Geologic map and sections of area west of Candelaria, showing relation of Lower Triassic Candelaria formation and Permian sandstone to folded Ordovician

8. Geologic map and sections of area east of Candelaria, showing principal section of Candelaria formation and its

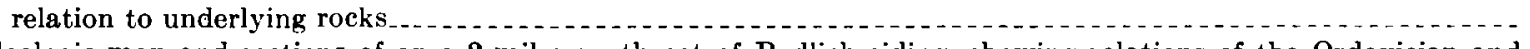

9. Geologic map and sections of area 2 miles southeast of Redlich siding, showing relations of the Ordovician and Permian and the Excelsior formation . . .

10. Geologic map and sections of part of Monte Cristo Range, showing outcrop of Monte Cristo thrust............. 



\title{
STRUGTURAL GEOLOGY OF THE HAWTHORNE AND TONOPAH QUADRANGLES, NEVADA
}

\author{
By Henry G. Ferguson and Siemon W. Muller ${ }^{1}$
}

\begin{abstract}
The area lies in west-central Nevada near the western border of the Basin and Range province. Paleozoic and Mesozoic rocks-the chief subject of this report-occur in isolated mountain ranges separated by stretches of Tertiary and Quaternary volcanic rocks, lacustrine deposits and alluvium. The report is concerned principally with the geology of the pre-Tertiary rocks and attempt is made to unravel the complex diastrophism that occurred in the area during the Jurassic.

Conformable Upper Triassic and Lower Jurassic marine sedimentary rocks underlie the northern part of the Hawthorne and the northwestern part of the Tonopah quadrangles. The basin of deposition, inferred from the lithologic variation of the Upper Triassic Luning formation, is here referred to as the Luning Embayment. In the southern part of the area this late Triassic embayment is thought to have had an easterly trend in contrast to the regional northeasterly trend prevailing along the geosynclinal area to the north and south. The older rocks, bordering the Luning Embayment on the south and east, range in age from Cambrian to Middle Triassic.

At least two periods of folding preceded the formation of the Luning Embayment-one earlier than the Permian, the other later than Permian but earlier than the late Triassic Luning formation. The beginning of Jurassic orogeny is indicated by the abrupt change from marine limestones and shales of the Sunrise formation (Lower Lias) to conglomerates and fanglomerates in the Dunlap formation (Upper Lias). These coarse clastic sediments were deposited in down-warped troughs within the Luning Embayment. The increase in the intensity of folding produced progressively greater angular discordance between the rapidly accumulating Dunlap deposits and the folded pre-Dunlap rocks. The Dunlap debris was derived for the most part from the rising areas of Sunrise, Gabbs, and Luning rocks.

Minor surface thrusts moved southward towards these troughs while the fanglomerate was being deposited. During the ensuing

more widespread folding and thrusting the previously folded rocks were bulged upward and stood in the way of later folds and thrusts. These uplifted areas impeded and deflected subsequent thrusts, causing local complexity of structure.

During the early part of the orogeny the thrusts for the most part did not cut the underlying Permian formation and Middle Triassic formations but were confined to the conformable Upper Triassic Luning and Gabbs, and Lower Jurassic Sunrise formations, and the unconformable Lower Jurassic Dunlap formation. The principal direction of folding and thrusting during the early stages was to the south.

Later thrusts of greater magnitude cut the underlying older rocks and carried slices of the Middle Triassic Excelsior formation above the previously deformed Upper Triassic and Lower Jurassic formations. Probably the morement along these thrusts was generally to the east although positive proof is lacking. Thrusts in the Paleozoic rocks bordering the Luning Embayment cannot be precisely dated.

A north-south flaw, along which horizontal movement was as much as 4 miles, crosses the southern part of the Luning Embayment. This fault is later than the early thrusts and may be of Tertiary age, or it may be associated with the later stages of Jurassic thrusting in the older rocks outside the Embayment.

The intrusion of the Sierra batholith and its satellites, generally believed to have taken place near the close of the Jurassic, apparently did not appreciably modify the previously formed structures.

Normal (Basin Range) faulting has been active from Miocene to the present. The varying trends of faults in different parts of the area are probably controlled by structures in the preTertiary rocks.

The stratigraphic and structural data that support the outlined sequence of diastrophic events are presented in greater detail in the description of the areal geology in the individual mountain ranges.
\end{abstract}

\section{INTRODUCTION}

The object of this paper is to describe the salient features of Jurassic diastrophism in parts of the Tonopah and Hawthorne quadrangles in west-central Nevada. The problem is complicated by the lack of continuity of exposures, earlier folding of the older rocks, metamorphism caused by the later granitic in-

\footnotetext{
${ }^{1}$ Field work on this report was completed in 1937 ; the manuseript was transmitted in 1938. Publication has necessarily been delayed owing to the war and other causes. During a part of the period we continued field work in Nevada, with short risits to the area in 1938 , 1939, 1940, and 1947, but it is inevitable that many statements made in this report would have been expressed differently if we were starting the work anew. A few changes and additions to the text have however been made.
}

trusions, and by superposed Tertiary and later normal faults.

\section{LOCATION}

The two quadrangles (fig.1) are bounded by parallels 38 and 39 and meridians 117 and 119 and include an area of 7,700 square miles, nearly as large as the State of Massachusetts. The region is bordered on the southwest by the Sierra Nevada, the southwestern corner of the Hawthorne quadrangle includes part of Mono Lake in California, and extends eastward through typical basin and range country to the middle of the State of Nevada. Within the region, the areas of exposed pre- 


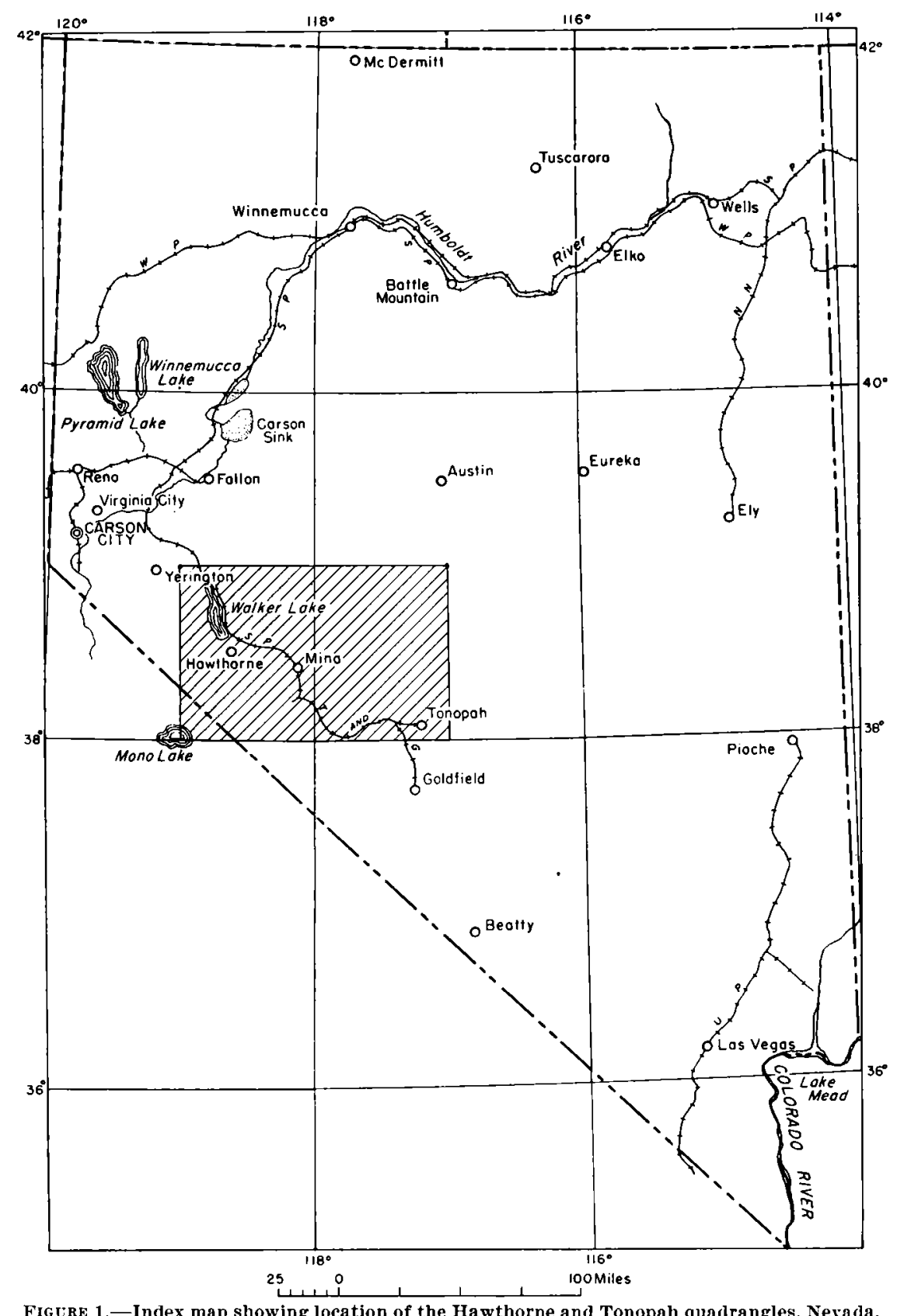

Tertiary rocks, including the intrusives and bordering metamorphosed rocks, constitute only about a fourth of the total surface and appear as an archipelago in an ocean of the later Tertiary and Quaternary formations.

\section{ACCESSIBILITY}

The region is easily accessible. A branch line of the Southern Pacific Railroad connects Mina with the main line at Hazen, a short distance east of Reno. There is also stage service from Reno to Mina and Tonopah and thence southward to Las Vegas.

An excellent improved high way crosses the two quadrangles, entering the Hawthorne quadrangle near the northwest corner, following the west shore of Walker
Lake to Hawthorne, and thence ruming through Soda Spring Valley and the valley south of the Monte Cristo range to Tonopah. Also a surfaced highway now (1947) runs south from U S 40 along the west flank of the Paradise Range and across the Gabbs Valley Range to Luning. Secondary roads radiate in all directions from the principal towns. Parts of the Wassuk Range hitherto inaccessible have been opened by excellent mountain roads built by the Civilian Conservation Corps under the supervision of the Navy Department and the Forest Service. Thanks to the widespread prospecting in the area, auto tracks lead from the main roads to many parts of the mountain ranges. The trafficability of these tracks depends, however, on the 
activity of prospecting and on the number and location of flash storms. An area easily accessible one season may next year be reached only after a painful amount of road building.

The Hawthorne and Tonopah topographic maps show the roads in existence at the time of the original surveys. in 1909 and 1907. Few of these now retain their indicated position. In the detailed maps, plates 2, 11. and 12 , the roads whose existence depends on the activity of mines and prospects have been omitted, even those that remained open during the entire period of our field work. The existing main roads are shown in approximately their positions in 1937. A geologist using the maps in the field, however, should locate himself by natural objects, not by road intersections or bends.

\section{PREVIOUS INVESTIGATIONS}

1870. EMMONS, S. F., Geology of the Toyabe Range, Nev., U. S. Geol. Expl. 40th Par. Rept., vol. 3, pp. 320-348.

1902. TURNER, H. W., A sketch of the historical geology of Esmeralda County, Nev., Am. Geologist, 29, pp. 261-272.

1903. SPURR, J. E., Descriptive geology of Nevada south of the fortieth parallel: U. S. Geol. Survey Bull. 208.

1915. HILL, J. M., Some mining districts in northeast California and northwest Nevada. U. S. Geol. Survey Bull. 594.

1921. KNOPF, ADOLPH, Ore deposits of Cedar Mountain, Mineral Co., Nev.: U. S. Geol. Survey Bull. 725, pp. 261-382.

1922. KNOPF, ADOLPH, The Candelaria Silver district, Nev.: U. S. Geol. Survey Bull. 735, pp. 1-22.

1922. CLARK, C. W., Geology and ore deposits of the Santa Fe district, Mineral Co., Nev. : Calif., Univ., Dept. Geol. Sci., Bull., vol. 14, pp. 1-74.

1924. FERGUSON, H. G., Geology and ore deposits of the Manhattan district, Ner.: U. S. Geol. Survey Bull. 723.

1927. FOSHAG, W. F., Quicksilver deposits of the Pilot Mts., Nev. : U. S. Geol. Survey Bull. 795, pp. 113-123.

1933. Callaghan, EUgene, Brucite deposit, Paradise Range, Ner. : Nevada Univ. Bull., vol. 27, no. 1.

1936. KERR, P. F., The tungsten mineralization at Silver Dyke, Nev. : Nevada Univ. Bull., vol. 30 , no. $\overline{5}$.

FIELD WORK AND ACKNOWLEDGMENTS

A recomnaissance of the geology of the Hawthorne and Tonopah quadrangles was made by $\mathbf{H}$. G. Ferguson and S. H. Cathcart in the summers of 1922,1923 , and 1924. Most of the work during the 1924 field season was accomplished by Catheart and W. F. Foshag. Ferguson made short visits to the area in 1929, 1930, and 1931 . This preliminary study yielded a knowledge of the general distribution of the principal formations, ${ }^{2}$ but it was found impossible to work out the complex structures by reconnaissance methods and on the scale of the available topographic maps $(1: 250,000)$. During this period T. W. Stanton ${ }^{3}$ twice visited the

\footnotetext{
2 Ferguson, H. G. and Cathcart, S. H. Major structural features of some western Nevada ranges: Washington Acad. Sci. Jour., rol. 14, pp. 376-379, 1924.

${ }^{3}$ Stanton, T. W., Two new faunas in the Marine Upper Triassic of Nevada: Science, new ser., vol. 63, p. 485,1926 .

\$11678-49- - 2
}

field party, and his study of the Mesozoic fossils made possible a preliminary determination of the stratigraphic section in the complex area of Upper Triassic and Lower Jurassic formations.

Muller * began his study of the Mesozoic stratigraphy of the area in 1927 , and at first confined his work largely to the New York Canyon area (pl. 5) which was mapped in detail in 1930 and 1931.

Joint field work by the authors had been started in a small way in 1931, but it soon became evident that the detailed stratigraphy as well as the structure of the areas of complex folding and thrusting could only be determined by mapping both the geology and topography on a larger scale. In the summer of 1934, with the assistance of a grant from the Penrose Fund of the Geological Society of America, mapping of the critical areas was started on a field scale of 1,000 feet to the inch. It had been hoped that such detailed mapping of small key areas with reconnaissance traverses of the intervening country would be sufficient; but as the work progressed it was found that one "critical" area led to another, and field work was continued under the auspices of the Geological Survey during the field seasons of 1935 and 1936 and a part of that of 1937 . The areas thus covered by detailed mapping include most of the terrain underlain by unmetamorphosed Upper Triassic and Lower Jurassic formations in the ranges bordering Soda Spring Valley (pl. 2) and small parts of the Paradise and Shoshone Ranges (pls. 11 and 12). The field maps of these areas, reduced to the scale of $1: 62,500$, have been adjusted to the topography of the original topographic map, enlarged to that scale. For several of the more complex areas reproductions of the larger scale field sheets are shown. A little detailed mapping was done also in the northern part of the Gillis Range (fig. 2), the Candelaria Hills (figs. 7, 8, and 9), the Monte Cristo Range (fig. 10), and the Toyabe Range (pl. 15). For the remainder of the area the data are in large part derived from the early reconnaissance by Ferguson, Catheart, and Foshag. though most of the principal areas underlain by unmetamorphosed pre-Tertiary rocks were revisited by the precent writers in the course of the later field work. The portion of the area mapped in detail perhaps approaches the equivalent of four 15-minute quadrangles out of a total of 32 in the entire area.

In the preparation of this paper, we have profited greatly from consultation and discussion with other geologists, and especially from the detailed criticism by T. B. Nolan of the Geological Survey, whose many

\footnotetext{
4 Muller, S. W., Upper Triassic stratigraphy of the Hawthorne and Tonopah quadrangles, Nev., (abstract): Geol. Soc. America Bull., rol. 42, p. 298, 1931; Marine Rhaetic in Nevada. (abstract) : Geol. Soc. America Proc. 1933, p. 389, 1934; Triassic coral reefs in Nevada: Am. Jour. Sci. 5th ser, vol, 31, p. 202-208, 1936
} 
suggestions for improvement of expression and arrangement have been appreciated and accepted.

The work was greatly aided by efficient field assistants during both the early reconnaissance and the later more detailed study, and our thanks are particularly due to Q. D. Singewald, H. H. Chen, G. C. White, J. F. McAllister, J. D. Barksdale, R. M. Dreyer, G. P. Sopp, and A. E. Granger.

\section{GENERAL GEOLOGY}

OUTLINE OF STRATIGRAPHY

DISTRIBUTION OF THE PRE-TERTIARY ROCKS

The general distribution of the exposed pre-Tertiary rocks of the two quadrangles is shown in plate 1 . The boundaries are generalized, and minor areas are omitted or greatly exaggerated.

The sediments of Upper Triassic and Lower Jurassic age (Luning, Gabbs, Sunrise, and Dunlap formations) occupy a roughly elliptical area in the eastern part of the Hawthorne and northwestern part of the Tonopah quadrangles. These formations are bounded by older volcanic rocks, which in part are of Middle Triassic age and in part are referred to the Permian. Early Paleozoic (Cambrian and Ordovician) formations crop out in the southern and eastern parts of the area. The eastern border of the Sierra batholith lies along the western margin of the Hawthorne quadrangle.

\section{PALEOZOIC ROCKS}

The Paleozoic rocks include Cambrian, Ordovician, Devonian, and Permian formations. Cambrian and Ordovician formations, each with a thickness of several thousand feet, are present in the eastern and southern parts of the Tonopah quadrangle and in the southeastern part of the Hawthorne quadrangle. In the San Antonio Range Devonian limestone rests on the Ordovician; elsewhere the Permian is unconformable upon the Ordovician. In the southern part of the area the Permian is thin and missing in places. It there consists for the most part of less than 100 feet of conglomerate, coarse grit, and sandstone, which in some localities is overlain by dolomite. The greatest thickness probably does not exceed 400 feet. In the northeast, on the other hand, the Permian of the Toyabe Range may be as much as 6,000 feet thick, the upper two-thirds being dominantly volcanic. There appears to be a gradation upward from basal fossiliferous sandstone and grit, similar to those of the southern area, through chert, bedded tuff, and occasional basic lava to the dominant greenstone and breecia of the upper part. The upper part also contains grit and fine-grained sediments identical in character with those of the lower part of the Permian but without fossils. Probably pre-Tertiary volcanic rocks in the Shoshone and Paradise Ranges are also Permian.

\section{MESOZOIC ROCKS}

The Mesozoic formations have been described in some detail, ${ }^{5}$ and only the major physical features will be noted here. More detailed descriptions of the lithologic variation of the Mesozoic formations in the different ranges will be found in the section on areal geology.

\section{TRIASSIC SYSTEM}

Candelaria formation (Lower Triassic).-The Candelaria formation is known only in the Candelaria Hills (figs. 7,8 ) in the southeastern part of the Hawthorne quadrangle. The formation consists of about 3,000 feet of thin-bedded shale, sandstone, and conglomerate containing pebbles of Ordovician chert. It rests with marked erosional but no obvious angular unconformity ( $m$ the Permian dolomite and grit and, where these have been completely eroded, on the upturned edges of the Ordovician strata. The upper contact is not exposed. The nearest outcrop of the next younger formation, the Middle Triassic Excelsior formation, is about 4 miles north of the northernmost exposure of the Candelaria formation; their relations are not known, but it is likely that the Candelaria and Excelsior are on different plates of a major thrust.

Grantsville formation (Middle Triassic).-The Grantsville formation is present only in the Shoshone Mountains in the northeastern part of the area (pls. 12, 13). The formation consists of conglomerate, slate, sandstone, and limestone to a maximum thickness of about 800 feet and contains fossils of Middle Triassic age. It is overlain by the Luning formation with erosional but apparently very small angular unconformity.

Excelsior formation (Middle Triassic).-The Excelsior formation consists dominantly of lava and tuff, and sediments, which are mostly derived from volcanic rocks. The lava shows more or less alteration and varies widely in petrologic character; but as it has not been studied in detail, the mafic varieties (largely andesite) will be referred to as greenstone and the more silicic (known to include rhyolite and quartzlatite) as felsite. Besides the lava and abundant breccia, considerable amounts of massive chert believed to be of tuffaceous origin, are interbedded with tuff and tuffaceous sandstone. The total thickness is estimated to exceed 12,000 feet. Volcanic breccia, with a little lava and bedded material, regarded as the basal part of the Excelsior, overlies the Ordovician unconformably in the southwestern part of the Monte Cristo Range and in the northern part of the hilly country west of Columbus Marsh. At the eastern end of Excelsior Mountain, the chert and bedded tuff, which form the lowest part of the section, are overlain by felsite and

\footnotetext{
s Muller, S. W. and Ferguson, H. G., Triassic and Jurassic formations of west-central Nevada: Geol. Soc. America Bull., vol. 47, pp. 241-251, 1936 ; Mesozoic stratigraphy of the Hawthorne and Tonopah quadrangles, Nev.: Geol. Soc. America Bull. vol. 50, pp. 1573-1624, 1939.
} 
felsite breccia. In the southern Pilot Mountains and southern part of the Garfield Hills the chert containing minor amounts of bedded tuff and tuffaceous sandstone is about 10,000 feet thick.

A few beds and lenses of limestone occur in the sediments between the lavas and breccias; but identifiable fossils, indicating probable contemporaneity of the Excelsior with the Grantsville formation, were found only in the Gillis Range, in the northwestern part of the Hawthorne quadrangle. At this locality adequate fossil evidence was obtained to date the volcanic rocks as Middle Triassic. That the similar volcanic rocks in the nearby ranges are also of Middle Triassic age becomes less certain with increasing distance from the Gillis Range area. Similar greenstones can be dated as Permian in the Toyabe Range in the northeastern part of the Tonopah quadrangle. The isolated patches of pre-Tertiary volcanic rocks in the southern part of the two quadrangles can be correlated with the Gillis Range Excelsior formation only with reservation and as a temporary expedient pending further investigation.

Luning formation (Upper Triassic).-The Luning formation is unconformable on the Excelsior and Grantsville formations and consists dominantly of limestone and dolomite, with varying amounts of slate, argillite, and conglomerate whose pebbles are largely chert. A complete section is not present in any one range; the probable thickness of the Luning is more than 8,000 feet in the Pilot Range but appears to be less in other areas. The lithologic character, particularly the proportion of slate and conglomerate, varies greatly in different ranges.

The mapping of the different lithologic units in the Luning revealed the structure in some detail in several of the ranges. The following lithologic units are shown on the detailed geologic maps (pls. 2, 11, 12):

Dolomite and limestone, undifferentiated: On the upper plate of major thrusts in the Gabbs Valley, Paradise and Shoshone Ranges, the Luning formation consists almost entirely of massive dolomite with some limestone, sufficiently different from the usual thin-bedded limestone and slate usually characteristic of the Luning to suggest that in these areas thrusting was on a sufficiently large scale to involve a considerable difference in facies. In most of these areas dolomite is in excess of the limestone, but as there is also evidence of widespread dolomitization along the thrusts, the proportion of original dolomite is indeterminate.

Upper limestone: In the Garfield Hills and southeastern Paradise Range below the thrust, there is no massive dolomite member at the top of the Luning, and limestone directly underlies the Gabbs formation; in the Gabbs Valley Range and Shoshone Mountains the thick limestone below the dolomite is included in this unit; in the Pilot Mountains this limestone forms the upper part of the exposed section but is not in contact with the Gabbs formation.

Thin beds and lenses of slate containing a small amount of conglomerate are present in the dolomite and upper limestone of the Gabbs Valley Range, Pilot Mountains, and Shoshone Mountains, but do not form mappable units. In the Garfield
Hills, on the other hand, a slate unit in the upper limestone is of sufficient thickness and continuity to be mapped separately (pl. 2).

Slate and conglomerate: These beds form the basal member of the Luning in the Shoshone Mountains, and the Garfield Hills but lie above the lower limestone in the Pilot Mountains.

Lower limestone: Thin-bedded limestone unconformably overlies the Excelsior in the Pilot Mountains and there is a limestone member below the slate in the southeastern Paradise Range, but not in normal contact with older formations.

As the facies change markedly within short distances, these units cannot be correlated on lithologic character alone from one range to another. The dolomitic member of the Luning in the Shoshone Mountains is believed to represent a different lithologic facies of the Luning brought into its present position by a horizontal dislocation of considerable magnitude. The slate members are at different horizons in different ranges; in the eastern part of the Pilot Mountains, the slate appears in part to interfinger with the lower limestone.

Along the southern margin of the Luning Embayment, as in the southern Garfield Hills and Pilot Mountains, the Luning contains much conglomerate whose pebbles are derived from the underlying Excelsior. In the Pilot Mountains such conglomerates occur as much as 3,000 feet above the base of the formation, and in the Garfield Hills there is also a little conglomerate in the upper slate member. In contrast, the Luning of other areas contains very little conglomerate above the basal member. Furthermore, there are no outliers of Luning on the older rocks that border it to the south and east in the Tonopah and Hawthorne quadrangles. It is improbable, therefore, that these sediments originally extended far to the east and south beyond the present outcrops of the Luning, and it is considered that the site of deposition was an eastward embayment of a major Upper Triassic geosyncline that included a large part of the area of the present Sierra Nevada. This basin which will be referred to as the Luning Embayment, seems to have greatly influenced the structure of the region.

Gabbs formation (Upper Triassic).-The Gabbs formation is the highest unit of the Upper Triassic and is conformable on the Luning but with sharp change in lithology. In the Gabbs Valley Range (pl. 5), the Gabbs formation overlies the massive dolomite at the top of the Luning; in the Garfield Hills and Shoshone Range it rests on the limestone of the Luning. It consists of shale and thin-bedded limestone and at its type locality, New York Canyon, in the Gabbs Valley Range, has a thickness of 420 feet.

\section{JURASSIC SYSTEM}

Sunrise formation (Lower Jurassic).-The Sunrise formation is conformable on the Gabbs and lithologically very similar except that it contains a little sand- 
stone. The type section in the upper part of New York Canyon has a thickness of 1,240 feet (pl. 5 ).

The Gabbs and Sunrise formations are essentially a single lithologic unit, which is relatively incompetent as compared with the underlying more massive limestone and dolomite of the upper part of the Luning formation. Except in Cedar Mountain, either or both the Gabbs and Sunrise formations are found in all the ranges in which the Luning is present, and not elsewhere; consequently their original distribution is inferred to be essentially coextensive with that of the Luning formation.

Dunlap formation (Lower Jurassic).-The character and relations of the succeeding Dumlap formation vary greatly in the different ranges, and details are given in the description under areal geology.

The principal area of deposition appears to have been along the southern margin of the Luning Embayment (pl. 2), where the Dunlap was deposited in a basin or basins in part overlapping the contact of the Excelsior and Luning formations. In this marginal area the Dunlap overlies both Luning and Excelsior with marked angular unconformity. The angular discordance in contacts with the Luming is generally less than $20^{\circ}$ though locally greater, but the discordance with the Excelsior is locally as much as $90^{\circ}$ in the Pilot Mountains. At a distance from the margin of the Luning Embayment the Dunlap is locally conformable on the Sunrise formation, as in New York Canyon, the northern Garfield Hills, and the area northwest of Garfield Flat, or overlies the Sunrise with erosional but no marked angular uneonformity, as in Sunrise Flat and the southwestern Garfield Hills. The maximum thickness is about 5,000 feet.

In most areas, particularly where the Dunlap rests on chert of the Excelsior formation, the lower part of the formation consists principally of red sandstone containing lenses of chert pebbles as well as a basal conglomerate of varying thickness.

Thin limestone and dolomite beds and lenses occur sporadically in the Dunlap and have vielded the few fossil collections obtained from this formation. In the Pilot Mountains these are near the top of the sandstone member; elsewhere, as in the Garfield Hills, they are more abundant in the lower part of the formation.

Lava and tuff are present in several areas. There is a single lava flow in the Dunlap of the northern Garfield Hills and two or three thin beds of greenstone breccia in the thick section of the Dunlap in the Pilot Mountains. In the Gabbs Valley Range, the southern Garfield Hills, and the central part of the Excelsior Mountains, on the other hand, the volcanic rocks in the upper part of the formation have a thickness that in the two southern ranges may be as much as 2.000 or 3,000 feet. The felsite and greenstone flows and breccias are similar to those of the Excelsior formation but contain more interbedded sandstone than is characteristic of the Excelsior, and the thick sections of chert and bedded tuffs of the Excelsior are not present in the Dunlap formation.

Conglomerate and fanglomerate, whose pebbles consist largely of dolomite and limestone from the Luning, form the upper part of the formation in the Pilot Mountains and norther'n Grifield Hills. These appear to have been deposited in local troughs formed during the early stages of folding. 'These troughs received the coarse fragments eroded from the folded Luning. In places Dunlap deposition continued during the early stages of thrusting, and conglomerate formed of material from the upper plate of a thrust was overridden by the same thrust.

The formation of these local troughs containing conglomerate and fanglomerate may have been approximately contemporaneous with the volcanism, the products of which form the upper part of the section in other parts of the area. In the Pilot Mountain and northern Garfield Hills this coarse conglomerate and fanglomerate is above lava flows interbedded with the underlying sandstone; in the Gabbs Valley Range, on the other hand, fanglomerate containing pebbles largely from the dolomite unit of the Luning formation is below the rolcanic portion of the Dunlap.

\section{INTRUSIVE ROCKS (JURASSIC?)}

All the Mesozoic formations are cut by granitic intrusions. The proportion of the area underlain by granitic rocks increases westward to the Sierra Nevada, which is only a few miles west of the Hawthorne quadrangle, and the granitic rocks of the Wassuk Range and the western part of the Excelsior Range are essentially continuous in outcrop with those of the Sierra batholith.

A variety of rock types is represented in these intrusions. Granodiorite predominates among the coarse-grained rocks, followed by quartz monzonite, quartz diorite, granite, and diorite in approximate order of abundance. The more basic rocks are notably scarce, and, as they are more abundant in areas underlain by the Excelsior than in the higher formations, may be in part of Middle Triassic age.

Wherever cross-cutting relationships were observed among the coarser-grained granitic rocks, diorite appears to be older than the more silicic bodies, but the larger areas of intrusive rocks have not yet been studied.

In their reconnaissance of the Wassuk Range in 1924, Catheart and Foshag found cross-cutting relationships among the various granitic masses, but it could not be determined whether these represented distinct intrusive periods or merely different stages of the same period.

Small masses and dikes of a very fine-grained siliceous rock consisting essentially of quartz and sodic plagio- 
clase are widespread throughout the area. These are referred to as aplite in the descriptions but differ from the typical granular aplite dikes of the larger granitic areas in their extremely fine-grained texture and the flow structure that is present in places. Irregular intrusive masses of aplite are abundant in the Excelsior formation of the Wassuk Range and neighboring areas along the margin of the Sierra batholith, but elsewhere the distribution of these fine-grained intrusive rocks does not show any close comnection with the coarsegrained granitic masses. Conmonly aplite is found along faults and forms sills in the thinner-bedded rocks, particularly the slate and limestone of the Galobs and Sunrise formations and the slate members of the Luning.

The granitic intrusions in general appear to be independent of the immediately surrounding structure. though in several places they took advantage of preexisting faults. Little or no doming of the invaded rocks is observable. The aplite follows closely the preexisting structures but locally seems to have displaced the invaded rocks.

\section{TERTIARY ROCKS}

The Tertiary formations overlie and largely conceal the structures in the area, and Tertiary faulting and tilting in places complicate the older structures.

The oldest 'Tertiary rocks are lavas of varied composition, and contain minor interbedded sediments. It is considered likely that the lavas are of Miocene age. ${ }^{7}$ They are overlain unconformably by the Esmeralda formation, which is of late Miocene and, according to Stirton, ${ }^{8}$ also early Pliocene age, and consists of various types of fresh-water and subaerial sediments interbedded with flows and tuff predominantly rhyolitic. There is some evidence that block faulting preceded the deposition of the Esmeralda formation and that the Esmeralda was in part at least deposited in basins formed by such faulting. In places a considerable thickness of rhyolite lies conformably on the Esmeralda formation, and stocks of the same composition cut and distort the beds. Unconformable on these is a thick series of andesite and andesitic agglomerate, presumably of Pliocene age. In the Toyabe and neighboring ranges a thick series of quartz latite flows also overlies the Esmeralda formation unconformably. An erosion surface, preserved on the crests of the present ranges, truncates the tilted and faulted andesite and quartz latite. Basalt flows and underlying gravels referred to the Pleistocene are later than this erosion surface, and in the southern part of the Hawthorne quadangle

\footnotetext{
7 Nolan, T. B., The underground geology of the western part of the Trnopah mining district. Nev. : Nevada Univ. Bull., vol. 24, no. 4. 1930.

Stirton, R. A., Succession of North American continental Pliocene mammalian faunas: Am. Jour. Sei., 5th ser., vol. 32, p. 183, 1936.
}

basaltic cones and flows are so recent that they have undergone little erosion.

\section{DIASTROPHIC HISTORY}

The diastrophism of Jurassic age was superposed on rocks which were previously folded, and this Jurassic folding and thrusting appears to have been most intense in the area of the Luning Embayment.

Conclusions in this report, drawn from study of the uncomnected areas of pre-Tertiary rocks, are not of equal value, and many of these areas have been incompletely studied. For greater clarity, the major structural features and the diastrophic events that affected the whole area are briefly summarized before the preTertiary stratigraphy and the structure of the individual mountain ranges are described in as much detail as seems justified by their significance in the general scheme and by the time devoted to their study.

\section{PRE-JURASSIC DEFORMATION}

The area appears to have been within a region that has shown marked crustal instability since the late Paleozoic. There were at least two episodes of folding prior to the Jurassic, one before the deposition of the Permian sediments and one later then the meta-rolcanic rocks of the Pilot Mountains and Garfield Hills mapped as Excelsior formation (p. 8). Erosional unconformities, which lack marked angularity but are indicated by wide rariations in the thicknesses of the formations, suggest intermediate phases of epeirogenic uplift. The trend of the earlier folds was generally easterly in the southern part of the area and northerly in the eastern part, and these trends appear to have exerted some control over the pattern of subsequent deformation.

\section{PRE-PERMIAN FOLDING}

Nolan ${ }^{\circ}$ has shown the presence in this region of a geanticlinal area in which marked uplift began at the close of the Devonian and exposed a wide area to erosion until the beginning of the Permian. He draws the axial line of this uplift diagonally through the Tonopaln quadrangle about N. $15^{\circ}$ E. from the southwest corner. $\mathrm{He}^{10}$ consider's that :

The evidence afforded by structural data in the Hawthorne and Tomopah quadrangles is interpreted to mean that elevation along the geanticline was accomplished by folding or warping on so broad a scale that the angular discordance beneath the overlapping Permian is scarcely discernible. In view of the thickness of beds that were probably removed, this implies that a fairly wide area was involved. Locally, however, the elevation was accompanied by more intense folding, as in the Candelaria Hills-Miller Mountain area.

${ }^{9}$ Nolan, T. B., A late Paleozoic positive area in Nevada: Am. Jour. Sei., 5th ser., rol. 16, pp. 153-161, 1928.

${ }^{10}$ Idem, p. 159 . 
The discordant relation between the Permian and Ordovician in the Candelaria Hills (pp. 45-47) is illustrated in figures 7 and 8 . In the western part of this area (fig. 7) a series of steep folds in the Ordovician strata, trending northeastward and in part overturned to the nortliwest, is overlain by Permian and Lower Triassic rocks that strike west and dip gently north. Similar angular discordance was noted in the vicinity of Candelaria. East of Candelaria (fig. 8) the discordance is less marked; the trend of the Ordovician rocks is westerly and about parallel to the overlying Permian and Lower Triassic, but the dips in the Ordovician are consistently steeper. There is also angular unconformity between the Permian and Ordovician in the Monte Cristo Range (fig. 10) and the hills to the west, and in the Toyabe Range (pl. 15). In these localities the general structural trends appear to be about parallel.

\section{UNCONFORMITY AT BASE OF LOWER TRIASSIC}

The Lower Triassic Candelaria formation is present only in the Candelaria Hills in the southern part of the area. Here it rests on the Permian with marked erosional unconformity and in places, where the Permian has been completely eroded, on the upturned Ordovician strata (fig. 8).

In contrast to the thinness of the Permian in the Candelaria Hills, the Permian of the Toyabe Range has a thickness of about 6,000 feet. As the upper part of the thicker section is composed of volcanic rocks, part of the discrepancy may be due to original thinning out of the volcanics to the south; but the almost complete erosion of even the lower sedimentary portion in the south indicates uplift of this area prior to the deposition of the Candelaria formation. It is possible that this marked difference may be explained by the existence of dissimilar facies now brought closer together by thrusting.

\section{UNCONFORMITY AT BASE OF MIDDLE TRIASSIC}

The contact of the Lower 'Triassic Candelaria formation with either of the Middle Triassic formations, the Excelsior and Grantsville is nowhere exposed, also the relations of these two Middle Triassic formations to each other are not known. In the Shoshone Mountains (pl. 13) the Middle Triassic is represented by only 800 feet of the sedimentary Grantsville formation, which rests with angular unconformity on Permian (?) volcanic rocks, and the Lower Triassic Candelaria formation is absent.

\section{PRE-UPPER TRIASSIC FOIDING}

In the few places where contacts of the Excelsior and Luning formations are exposed, the Luning overlies the Excelsior with marked angular unconformity. Else- where, the contact of the Excelsior and Luning is concealed by the overlap of the Lower Jurassic Dunlap formation, unconformable on both, but with greater angular unconformity above the Excelsior than above the Luning in the Pilot Mountains and southeastern Garfield Hills. The chert and interbedded tuff of the Excelsior formation is strongly folded and overturned toward the north, whereas the Luning formation to the north is thrust to the south (pl. 2, secs. $F-F^{\prime}$ and $\left.H-H^{\prime}\right)$. Because of its areal distribution, the Excelsior formation of these ranges is correlated with the known Triassic Excelsior, thus placing this period of folding between the Middle Triassic and Upper Triassic.

If, however, future work should prove these volcanics to be Permian, this folding could be dated only as preMiddle Triassic, for the Middle Triassic Grantsville formation in the northern part of the Tonopah quadrangle overlies unconformably folded volcanics thought to be Permian and is overlain by the Luning without marked angular unconformity.

\section{DEVELOPMENT OF THE IUNING EMBAYMENT}

The Luning Embayment is believed to represent a local easterly bight in the margin of a broad Upper Triassic seaway whose general eastem boundary followed a northerly course. The lithologic character of the Luning formation in the Pilot Mountains and Garfield Hills as compared with that in the ranges to the north indicates, however, that the limit of the Luning deposition in the central and eastern parts of the Hawthorne quadrangle, trended about east and west, probably not far from the present southern margin of the formation. In the northeastern part of the area, the limit of Luning deposition may have extended farther eastward because in the Shoshone Mountains thrusting from the east has carried the massive limestone and dolomite facies above the more usual facies consisting of shale and limestone.

The warping that determined the broad outlines of the Luning Embayment seems to have been controlled by preexisting structure, but it cannot be determined to what extent the present trends of the older rocks are the result of superimposed folds during the early Jurassic diastrophism. However, the folds overtumed northward in the Excelsior formation of the Pilot Mountains and Garfield Hills as opposed to the thrust southward of the nearby Luning formation, indicate that at least the easterly trend of the southern border of the Embayment was controlled by older structural trends.

Within the Luning Embayment about 10,000 feet of conformable strata-the Luning, Gabbs, and Sunrise formations-were deposited. At least 8,000 feet belong to the Luning formation, which is composed dominantly of limestone and dolomite with an increasing proportion of conglomerate in the marginal areas. 
The coarse conglomerates in the lower part of the Luning formation suggest that there may have been locally considerable topographic relief. Irregularities in outline and inequalities of either erosional or structural origin in the floor may have influenced the later structures. The mass of the Excelsior formation in the southeastern Garfield Hills, between Mina and Luning, may have persisted as an island throughout at least a part of the period of Luning deposition. There is no evidence that the depositional area of the Sunrise and Gabbs formations differed essentially from that of the Luning.

\section{JURA SSIC OROGENY}

\section{SEQUENCE OF EVENTS}

The areas of pre-Tertiary rocks are isolated from one another by a cover of later formations; consequently, even where the rocks are sufficiently unaffected by igneous metamorphism to permit a satisfactory solution of the local structure, correlation of these individual structural features from one range to another cannot be made with certainty.

As far as can be determined from the fragmentary record, the major events in the Jurassic orogeny appear to have taken place in the following order:

1. Warping which resulted in the deposition of the lower, dominantly sandy part of the Lower Jurassic Dunlap formation in a broad basin whose southern border overlapped the margin of the Luning Embayment.

2. Local folding and minor thrusting affected the Luning formation chiefly at the southern margin of the Embayment. At the same time, restricted structural troughs received the detritus from the upfolded Luning and from the advancing surface thrusts. This detritus formed the upper conglomeratic and fanglomeratic portion of the Dunlap formation, and its deposition was contemporaneous with volcanism in other parts of the area.

3. Spreading of the disturbance northward while thrusting and folding on a larger scale complicated the earlier structures. At the same time the earlier folded and compacted areas were uplifted so that the contemporaneous folds and thrusts were in part warped and in part deflected by the areas of uplift. The movement in this stage was still dominantly southward, and for the most part the thrusts involved only the Iuning and higher formations.

4. Thrusting continued on a still larger scale but as far as could be determined was directed mainly east ward or southeastward, and the thrusts carried slices of the underlying Excelsior formation above the Luning. The Shoshone thrust (p. 42) and the most northerly thrust in the Toyabe range (p. 53), however, show relative westward movement.
5. Thrusting within the Paleozoic rocks bordering the Embayment may have been late in the sequence but cannot be dated with relation to the movements involving the Mesozoic rocks of the Embayment.

6. Horizontal displacement along a major flaw in the present site of Soda Spring Valley may have been initiated at this time but there is some evidence that movement took place during the Tertiary.

7. The intrusion of granitic rocks was the last major event in the pre-Tertiary structural history of the region.

\section{EARLY JURASSIC WARPING AND DUNLAP SEDIMENTATION}

The deposition of the Dunlap sediments marked the beginning of the early Jurassic orogeny and followed the accumulation of the conformable marine Upper Triassic and Lower Jurassic sediments within the Luning Enbayment. The lower part of the Dunlap formation consists dominantly of red cross-bedded sandstone with varying amounts of conglomerate. Here and there are beds and lenses of marine limestone, and marine fossils have been found in a few of the red sandstones associated with the calcareous beds.

The original extent of Dunlap sediments is uncertain as the formation is preserved only within synclines or below the later thrusts; however, present distribution of the Dunlap formation suggests that the area of deposition roughly paralleled the southern border of the Luning Embayment but overlapped the contact of Luning and Excelsior and extended beyond the southern margin of the Luning, as in the Excelsior Mountains (pl. 2) and at the southern ends of the Cedar and Toyabe Ranges (pl. 1).

In the northwestern Garfield Hills and the Gabbs Valley Range (pls. 2, 5; fig. 5), at some distance north and west of the margin of the embayment, the Dunlap is locally conformable on the Sunrise formation or shows only moderate erosional unconformity, and the conglomerates contain principally pebbles derived from the Luning and Sunrise formations.

The small area of Dunlap in the northeastern part of the embayment, above the Sunrise formation in the Shoshone Mountains (pl. 12), indicates that the formation originally extended northward as far as the northern border of the Tonopah quadrangle.

\section{LOCALIZED FOLDING AND THRUSTING AND DEVELOPMENT OF STRUCTURAL TROUGHS}

The beginning of more intense folding produced restricted troughs, into which poured the coarse fanglomerates and conglomerates derived from the rising folds of the Luning formation and in part from advancing thrust plates.

The two principal troughs, possibly originally continuous, are those of the northwestern Pilot Mountains and northern Garfield Hills (pl. 2). 'These troughs are 
at the contact of the Luning and Excelsior formations; that of the Pilot Mountains is at the margin of the Luning Embayment, but the Garfield Hills trough borders an inlier of Excelsior north of its southern border. In the Pilot Mountains the upper 1,500 feet of the Dunlap formation consists essentially of conglomerate and fanglomerate derived from the Luning. In the Garfield Hills the upper 1,000 feet consists of similar conglomerate and fanglomerate.

The parts of both troughs that had the sharpest original relief seem to have been of relatively small area in spite of the great thickness of sediment that accumulated. Any attempt at reconstruction involves considerable uncertainty for, except along their southern borders, the coarse sediments of the troughs are involved in the close folding of the Luning or are overlapped by later thrusts; but the Garfield and Pilot troughs are each about 12 miles from east to west by 4 or 5 from north to south.

Folding during Dunlap deposition in the Garfield Hills trough was relatively gentle, for the greatest angular discordance observed between Luning and Dunlap does not exceed $20^{\circ}$; but depression of the trough continued during folding, for the limestone conglomerate of the Dunlap, which is folded with the Luning, lies on the truncated earlier folds of the Luning.

In the northwestern part of the Pilot Mountains (pp. 30-33) thrusting as well as intense folding appears to have occurred during the early stages of deformation, possibly because complications were introduced by the southward pressure of the interior ridge of Excelsior, now represented by the mass on the north wall of Mac Canyon. The two earliest thrusts, the Mac and Spearmint (see pls. 3, 7,8 ), were formed during this period of early compression, and conglomerate and sandstone of the Dunlap were deposited on the surface in front of the Mac thrust while movement over that surface was in progress. As the upper plate of the Mac thrust moved into the trough, which continued to downwarp, the buckling of the thrust plane together with the accelerated accumulation of waste impeded further southward movement. As the Mac thrust thus "bogged down" in the conglomerate of the Dunlap, continued pressure from the north forced a new break along which the Spearmint thrust overrode the erosion surface cut on the upper plate of the Mac thrust, and the Spearmint thrust also may have been blocked by sagging of the thrust plane as depression of the trough continued and waste accumulated (pl. 3). Further pressure was then relieved by the folding of both thrusts, necessarily asymmetrical, as their original planes were divergent, and by the formation of new thrusts to the north.

These two folded thrusts originally developed in folded rocks; consequently, the succeeding folding, which buckled the thrust planes themselves, resulted in extremely complex structures in the different thrust plates. It was not possible to work out in cletail the structure of the strongly folded block of upper limestone in the Luning between the Mac and Spearmint thrusts, but the involution of the recumbent syncline in the upper plate of the Northwest thrust (pl. 8), at least in large part, is ascribed to this continued folding.

The overturning and minor southward thrusting on the east flank of the northern Garfield Hills (pp. 19-20), south and southwest of Luning, are comparable with the close folding north of the Excelsior mass at Mac Canyon.

In both the Garfield and Pilot troughs lava flows underlie the coarse fanglomerate in the Dunlap. Elsewhere in thick sections of the Dunlap formation, the upper part consists largely of volcanic materials more or less interbedded with sandstone and conglomerate. In the Gabbs Valley Range, the lower part of the Dunlap formation beneath the volcanic rocks contains conglomerate and fanglomerate consisting exclusively of pebbles derived from the Luning and Sunrise formations. If the beginning of volcanism can be used as a datum, this fanglomerate in the Gabbs Valley Range indicates at least local folding earlier than that of the Garfield and Pilot troughs and possibly soon after the close of Sumrise deposition, for in this range the Dunlap is in places apparently conformable on the Sunrise and elsewhere rests on the Sunrise with only moderate erosional unconformity.

\section{FOLDING AND THRUSTING IN THE LUNING EMBAYMENT}

After the early deformation which seems to have been largely concentrated along the southern margin of the embayment, the area of folding and thrusting spread northward. Thrusts of larger magnitude crowded against the earlier folded areas further complicating the structure. At the same time uplift of these areas appears to have in part warped and in part deflected the later thrusts and to have caused local back-folding and change in trend of the folds. The direction of movement was still dominantly southward, and the deformation was most intense near the southern margin of the embayment. Most of these thrusts do not involve formations older than the Luning.

Uplift of previously folded areas.-It is believed that uplift of the folded area bordering the Dunlap troughs of the Garfield Hills and Pilot Mountains was in progress during most if not all of this stage. In the northern Garfield Hills, east of Garfield Peak (pl. 2; fig. 3), and in the northwestern Pilot Mountains (pls. 2,7), this uplift and compaction of the previously folded area diverted the trend of the later folds and caused local backfolds which in places developed into small thrusts.

Most of the later thrusts appear to have been in part deflected around the uplifted area causing the later thrusts to move along alternating gently and steeply dipping planes. Such sharp changes in attitude of the 
thrust planes cannot be due to subsequent folding of the thrust plane, for the rocks on the upper and lower plates do not show concordant folding. The steeply dipping segments of the thrust plane are not tear faults, for the upper plates are not split. This "stepping down" along the steeper segments is directed away from the area of uplift, suggesting that it resulted from opposition to movement offered by the uplifted and compacted mass containing the earlier folds. Such sharp changes in strike and dip characterize the East Ridge thrust in the Pilot Mountains (pl. 2). This thrust has two steeply dipping northward-striking segments that pass into segments in which the plane strikes east and dips gently to the north. A similar structure is also seen in the small thrust above the East Ridge thrust. The klippe of the Marble Quarry thrust, northwest of Garfield Flat (pl. 2; fig. 5), is similarly bounded by a steep plane on the east and one with gentle dip on the west.

This combination of alternate gently and steeply dipping planes may indicate movement under light load. Other irregularities of thrust planes may also indicate relatively shallow depth or movement over an erosion surface; but for most of the thrusts, it is impossible to determine to what extent such irregularity may be due to later warping.

The change in direction and attitude of the folds bordering the areas of earlier folding in the Garfield Hills and Pilot Mountains may have resulted from deflection of later folds by and during the uplift of these areas. In the northern Garfield Hills the prevailing westerly trend of the folds changes sharply to a southwesterly trend, and locally these folds are overturned to the northwest (secs. $C-C^{\prime}$ and $D-D^{\prime}$, pl. 2). Similarly, in the northwestern Pilot Mountains the folds above the Dunlap Canyon thrust change in trend from east to southeast and at one point are overturned to the northeast (sec. $B-B^{\prime}$, pl. 7 ).

Thrusts within the Luning formation.-Many of the smaller thrusts along the margin of the embayment seem to have developed from the rupture of folds in weaker rocks that were crowded against the resistant marginal rocks, and from rupture of recumbent folds. Among these are the thrust of the Sunrise against the Luning and Excelsior in the southwestern Garfield Hills (secs. $A-A^{\prime}, B-B^{\prime}$, pl. 2) and some of the earlier thrusts in the complexly folded areas of the eastern Garfield Hills and northwestern Pilot Mountains.

Later, more widespread compression resulted in larger thrusts. The thrusts of this group apparently moved at shallow depth, overriding in part the earlier surface thrusts of the Pilot Mountains and overlapping the surficial folds of the Garfield Hills. For only one of these thrusts, however, does the presence of thrust conglomerate give clear evidence of movement at the surface. The New York Canyon thrust of the Gabbs
Valley Range (fig. 6 and p. $2 \overline{6}$ ) brings the dolomite of the Luning above the volcanic member of the Dunlap formation and shows a succession of thin plates of dolomite overlying conglomerate composed of dolomite pebbles. This is interpreted as indicating the pulsatory advance of a surface thrust, each advance of the upper plate having been nearly balanced by erosion at the front of the plate during the itervening quiet period. Several thrusts, such as the Garfield, Marble Quarry, and Ashby thrusts of the Garfield Hills and the East Ridge thrust of the Pilot Mountains, override the Dunlap formation and also carry unconformable Dunlap on the upper plate, so they too must have moved at or near the surface.

These thrusts appear to be confined to the probable area of Luning deposition. No klippen are found on the basement rock bordering the Luning, though several thrusts carry the Luning against the marginal Excelsior. The island-like masses of Excelsior in the southeastern Garfield Hills and in the northwestern Pilot Mountains are thrust over the Luning, but other thrusts involve only the Luning and younger formations.

Probably many of these thrusts originated at the base of the Luning, or along berlding planes within the Luning, and broke through to the surface as movement reached a zone of increasing resistance near the marginal Excelsior. Isolated masses of greenstone of the Excelsior formation thrust over the Luning in the Garfield Hills and northwestern Pilot Mountains, may have been irregularities in the Excelsior basement that were sliced off by thrusts originating at or near the contact of the Luning and Excelsior formations. For the most part, however, the basement rocks were involved in the deformation only to a slight extent, and it is believed that these thrusts tore the Luning from its moorings and carried it toward the borders of the embayment.

The earliest thrusts generally were formed nearest the margins. Such a sequence would accord with the greater folding of the Luning observed in the lower thrust plates of the Pilot Mountains and the folding and warping of the lower thrust planes themselves. But if the assumed connection of the isolated thrust segments mapped as the Garfield Flat thrust (p. 20) is correct, it would appear that this thrust carried southward the entire mass containing the Garfield trough and bordering folds; similarly later southward movement of the earlier folder rocks of the northwestern Pilot Mountains seems to have taken place along the Cinnabar Canyon thrust (pl. 3 and p. 35).

If the assumption of a flaw in Soda Spring Valley is valid (p. 14), the Garfield Flat and Cinnabar Canyon thrusts may be parts of the same thrust.

The Paradise thrust (pl. 11 and p. 40) and the Shoshone thrust (pl. 12 and p. 42) may be of larger displacement than the marginal thrusts as they involve 
somewhat different facies of the Luning formation. On the upper plates of both thrusts is thick massive dolomite and limestone differing from the interbedded limestone and slate of the lower plates. Some slate is also present, however, in the upper plate of the Paradise thrust. The proportion of dolomite due to secondary dolomitization cannot be determined but it is significant that it is only sporadically present in the limestones of the lower plates. Relative movement of the upper plate of the Paradise thrust appears to have been to the east, but for the Shoshone thrust crumpling of the incompetent formations of the lower plate definitely indicates relative movement of the upper plate to the southwest or west.

Movement on the thrusts within the Luning cannot be measured, but it is assumed to be generally small, since, except on the Paradise thrust (p. 40) the Shoshone thrust (p. 42) and in less degree on the New York Canyon (p. 26) and East Ridge thrusts (p. 36), no major difference of facies of the Luning is involved. The lithologic character of the Dunlap varies so greatly in short distances that the presence of different facies in that formation on upper and lower thrust plates is no criterion of major movement. Possibly the average magnitude is of the order of a few miles.

Folds and thrusts opposed to the general southerly movement.-During this stage, although the dominant movement was to the south, local impediments to such movement caused the development of minor opposed structures. The back-folding around the areas of uplift in the Garfield Hills and the Pilot Mountains has already been mentioned. Such folds are overturned to the northwest in the vicinity of Garfield Peak and to the northeast in the Pilot Mountains. In the Garfield Peak area there are also small northwesterly thrusts of Excelsior over Luning. There are small southdipping thrusts in the upper plate of the New York Canyon thrust in the Gabbs Valley Range (pl. 5, and p. 26). These appear to be confined to a segment of the upper plate lying between two tear faults and are regarded as the result of impeded movement of this segment while the bordering segments moved forward more freely.

Other structures produced by northward movement within the Luning embayment are the West Ridge thrust of the Pilot Mountains (pls. 7, 8 and p. 36), the overturned syncline in Cedar Mountain, probably present also in the hills to the east (p. 39), and the overturned Dunlap along the border of the Excelsior formation north of Garfield Flat (fig. 3).

\section{LARGE-SCALE THRUSTING}

Thrusts apparently from the west and northwest, which carried slices of the Excelsior formation, over- rode the earlier structures produced by thrusting from the north. This later thrusting appears to have been of greater magnitude than the earlier.

Both the McGee and Pamlico thrusts in the western part of the Garfield Hills cut the Excelsior formation, though relatively thin slices are involved, for in the upper plate of each the Luning unconformably overlies the Excelsior. The Gillis thrust, which brings Excelsior over Luning on the east flank of the Gillis Range (fig. 2 and p. 16), has cut more deeply, for the Excelsior on the upper plate is several thousand feet thick. The Gillis thrust probably extends as far to the southeast as the northwestern part of the Garfield Hills and possibly northeastward to the southern end of the Paradise Range (p. 40). It is considered to be later than the McGee and Pamlico thrusts, which themselves are later than the thrusts and folds which involve only the Luning.

The relative direction of movement of the upper plates of these larger thrusts appears to have been toward the east, or possibly the southeast, in contrast to the prevailingly southward direction of the earlier folds and thrusts.

DEFORMATION OF THE MARGINAL PALEOZOIC ROCKS

Thrusts within the Paleozoic rocks bordering the Luning embayment cannot be definitely placed in the sequence, and, especially those of the Toquima and Toyabe Ranges, (pp. 51-53) may be pre-Jurassic.

The Monte Cristo thrust, carrying Permian and Ordovician rocks over the Excelsior formation and underlying Ordovician, crops out in the fenster in the northwestern part of the Monte Cristo Range (fig. 10 and p. 48) and in the hills south of Redlich (fig. 9 and pp. 47-48). The upper plate is thought to have moved eastward. Movement of considerable magnitude is suggested by the difference in facies of the thrust plates. At least a post-Paleozoic age is indicated by the presence of the Excelsior formation and probably also the Candelaria formation.

The thrusts of the Toquima and Toyabe Ranges may possibly be of earlier date, but at least as late as Permian. The structure of the Toyabe Range (pls. 1, 15, and p. 53) differs from that of other parts of the area in that the thrusts are associated with steeply dipping faults, some of which can best be interpreted as large flaws. An eastward-dipping thrust at the northern border of the quadrangle brings Ordovician rocks above Permian. Elsewhere the predominant movement seems to have been toward the east or northeast, and the thrusts involve slices of highly folded Cambrian and Ordovician rocks.

In the Toquima Range (p. 51) thrusting, probably not of great magnitude, was toward the north and brought Cambrian rocks above Ordovician. 


\section{OTHER FAULTS}

The region contains many normal faults, some of considerable magnitude; but on most of them the principal movement took place during the period of "Basin Range" faulting, beginning probably in the early Tertiary and continuing to the present. Relations with Tertiary lava and physiographic evidence prove that relatively recent movement took place on most of these faults. For others, parallelism with known Tertiary faults suggests a Tertiary age.

Pre-Tertiary normal faulting was of relatively minor amount. Dominant horizontal movement is suggested for most of the larger steep faults that can be shown to have originated prior to the Tertiary; but on several of them, as in the faults that cut the New York Canyon thrust in the Gabbs Valley Range (pl. 5) and the Northwest thrust in the Pilot Mountains (pl. 7), vertical movement may have been superposed in Tertiary time. In the Toyabe Range and the Shoshone Mountains, however, though major horizontal movement is suggested along the principal faults, others appear to be pre-Tertiary normal faults.

Elsewhere, movements having a major vertical component seem to have resulted largely in local uplifts and troughs in the initial stage of the orogeny, and in the succeeding uplift of the areas of earliest folding. No evidence was found of alternating periods of compression and tension such as were described by Nolan from the Gold Hill district. ${ }^{11}$

\section{INTRUSION OF GRANITIC ROCKS}

The development of the pre-Tertiary structural features of the area was essentially complete before the intrusion of the granitic rocks which occupy such a large part of the area but which appear to have had little direct influence on the structure. Only rarely, as in the area where the Luning formation surrounds the granodiorite northwest of Sunrise Flat and the Cambrian area of Lone Mountain, do the sedimentary rocks dip away from the larger intrusive masses. Small aplite masses, however, have caused local doming, as in the New York Canyon area and the western Garfield Hills. Several of the thrusts are cut by intrusives, and many of the pre-Tertiary faults, whatever their dip, have been followed by small aplite or granite porphyry dikes. There is also a suggestion that some of the thrusts, as in the southern Gillis Range and the southeastern Garfield Hills to some extent directed the emplacement of the intrusive rocks.

\section{DATE OF DIASTROPHISM}

The structural history of the Jurassic diastrophism within the two quadrangles indicates an early stage

11 Nolan, T. B., The Gold Hill Mining district, Utah : U. S. Geol. Survey Prof. Paper 177, pp. 55-64, 1935. of southward compression which was controlled by a local easterly bend in the margin of the Upper Triassic geosyncline. This stage was followed by more widespread regional compression effected by major thrusts that moved generally eastward and southeastward. The intrusion of the Sierra batholith was later than all the major compressive movements. The early stage of folding and thrusting was well advanced before the end of deposition of the upper part of the Dunlap formation, which near its base contains fossils characteristic of the upper part of the Lower Jurassic (Upper Lias of the European section) . ${ }^{12}$ The succession of thrusts of the Pilot Mountains and Gabbs Valley range suggests duration through a considerable interval but the lack of normal faulting intermediate in time between the various thrusts implies that the diastrophism consisted of a single major phase rather than several alternating phases of compression and tension. The orogeny may therefore be earlier or may overlap in part the Nevadian orogeny as defined by Blackwelder ${ }^{13}$ but does not entirely coincide with it.

\section{POST-JURASSIC STRUCTURE}

The area included in the two quadrangles seems to be essentially free from the effects of the post-Jurassic orogenies, from Cretaceous to late Tertiary, which caused intense folding and thrusting in regions to the south and east. ${ }^{14}$

Thrusting.-There has been only minor thrusting definitely of postgranitic age. In the southern Garfield Hills, east of Garfield Flat, Luning and overlying Dunlap are thrust over granodiorite and diorite (fig. 4) but in the same area the granodiorite is intrusive into both the lower and upper plates. Many of the dikes and masses of aplite along the thrusts throughout the area are sheared, but there is no indication of major postintrusion movement. In the northern part of the San Antonio Range, a reverse fault brings Permian(?) volcanics above lavas of probable Miocene age (p. 48). Knopf ${ }^{15}$ has reported a reverse fault of 300 feet or more

12 Muller, S. W., and Ferguson, H. G., Mesozoic stratigraphy of the Hawthorne and 'Ionopah quadrangles, Nev.: Geol. Soc. America Bull., vol. 50, p. 1621,1939 .

13 Hlackwelder, E. A summary of the orogenic epochs of North America : Jour. Geology, vol. 22, pp. 643-645, 1914.

14 Longwell, C. W., Geology of the Muddy Mountains, Nevada with a section through the Virgin Range to the Grand Wash Cliffs, Arizona: U. S. Geol. Survey Bull. 798, 1928. Hewett, D. F., Progress in the survey of the Ivanpah quadrangle, Nevada-California (abstract) : Geol. Soc. America Bull., vol. 37, pp. 164-165, 1926; Geology and ore deposits of the Goodsprings quadrangle, Nev.: U. S. Geol. Surver Prof. Paper 162, 1931. Nolan, T. B., Notes on the stratigraphy and structure of the northwest portion of Spring Mountain, Nev.: Am. Jour. Sci., 5th ser., vol. 17, pp. 461-472, 1929 ; The Gold Hill mining district, Utah : U. S. Geol. Survey Prof. Paper 177, 1935. Noble, L. F., Structural features of the Virgin Spring a rea, Death Valley, California : Geol. Soc. America Bull. vol. 52, pp. 941-999, 1941. Merriam, C. W., and Anderson, C. A., Reconnaissance survey of the Roberts Mountains, Nevada: Geol. Soc. America Bull., vol. 53, pp. 1675-1727, 1942.

15 Knopf, Adolph, Ore deposits of Cedar Mountain, Mineral County, Nevada : U. S. Geol. Survey Bull. 725, pp. 380-381, 1921. 
displacement in the Tertiary lavas of the northern part of Cedar Mountain. The Tertiary lavas and sediments, probably all of Miocene and later age, are tilted and cut by normal faults, locally, as at Tonopah, resulting in highly complex structure; but major folding and thrusting are lacking.

Flaw in Soda Spring Valley.-The position of the different formations and structural elements on both sides of the southern part of Soda Spring Valley, south of Luning, suggests that this section of the valley may be the site of a large flaw along which the relative movement of the eastern side was about 4 miles to the south. If restored to their inferred original position, the major features of the geology (pl. 2) such as the boundaries of the Excelsior formation and the folded Luning to the north would be in closer accord, and thẹ Garfield Flat thrust on the west in approximate continuity with the probably contemporaneous Cinnabar Canyon thrust in the Pilot Mountains.

An outcrop of a fault possibly associated with this flaw was noted at the southern end of Soda Spring Valley, 2 miles south of Redlich, where the Monte Cristo thrust is displaced by a steeply dipping fault striking northwestward (fig. 9 and p. 48). Here however this strike is more westerly than assumed for the flaw to the north.

If such horizontal movement took place it must have been later than the early folding and intermediate thrusting for it cuts the earlier structures and also involves the basement rocks, both within and at the margin of the Luning embayment.

The southern part of Soda Spring Valley is bordered by recent faults, particularly on the east. There is no evidence of faulting in the northern part, northwest of the bend near Luning, but the belt of late faults continues along the strike of the inferred flaw into the southeast end of the Gillis Range and northern part of the Gabbs Valley Range. Physiographic evidence as well as the gravel scarps between the Pilot and Gabbs Valley ranges and the downfaulted Dunlap formation southeast of Soda Springs suggest dominant vertical movement for the most recent faulting. However, on the fault at the southeast end of the Gillis Range, easily eroded Tertiary rhyolite tuff on the downthrown east side is topographically above the more resistant granodiorite on the west. This is more compatible with horizontal than vertical movement. (See p. 29.)

The rifts between the Pilot Mountains and Cedar Mountain formed in the earthquake of 1932 are regarded by Gianella and Callaghan ${ }^{16}$ as indicating horizontal movement in a southerly direction of the block

\footnotetext{
${ }^{18}$ Gianella, V. P. and Callaghan, E., The earthquake of December 20, 1932 , at Cedar Mountain, Nevada, and its bearing on the genesis of Basin Range structure: Jour. Geology, rol. 42, pp. 1-22, 1934.
}

to the east of the Pilot Mountains, including the Paradise Range and Cedar Mountains.

In the concluding portion of this paper Callaghan ${ }^{17}$ suggests that this zone marks a portion of a major rift parallel to the San Andreas rift and the east front of the Sierra Nevada and on which horizontal movement has been in the same direction, but the aggregate horizontal shift between the Pilot Mountains and Cedar Mountain cannot have been large, for the major pre'Tertiary structures of the two ranges are in approximate continuity. The syncline that crosses Cedar Mountain, south of the granodiorite (pl. 1), is in line with that at the north end of the Pilot Mountains (sec. $I I-H^{\prime}$, pl. 2); and the Excelsior formation and orerlying Dunlap at the southern end of Cedar Mountain aline with the same formations in the Pilot Mountains, though the intervening thrust, if present, is concealed beneath the Tertiary lavil.

It is thought possible therefore that here the major rift may be a few miles west of the position indicated by Callaghan and that the rift between Pilot and Cedar Mountains, on which horizontal movement took place during the 1932 earthquake, is an auxiliary fracture.

Basin Range faulting.-The major Terticry and Quaternary faults of the two quadrangles (pls. 1, 2) show considerable variation in trend. This variation in the strike within short distances may be due in part to control by the older structures. The Basin Range faults in the northeastern part of the area, particularly the Toyabe Range and Shoshone Mountains, strike northward parallel to the general trend of the pre-Tertiary formations. Northwesterly strikes prevail in the faults of the central part of the area, from Cedar Mountain mestward to Soda Spring Valley. In this region the Tertiary and later faults are transverse to the structure of the older rocks but parallel to the inferred flaw in Soda Spring Valley. The normal faults in the southerm part of the Hawthorne quadrangle have strikes that in general accord with the regional structure of the older rocks-easterly in the Candelaria Hills and eastern Excelsior Mountains, swinging to the southwest in the western Excelsior Mountains and south end of the Wassuk Range. The faults trending northward to northwestward along the front of the Wassuk Range, border granitic intrusives, and their trends may have been determined by the position of the contact.

\section{AREAL GEOLOGY}

The pre-Tertiary structure of individual ranges is described in such detail as is necessary to support the conclusions set forth above concerning the diastrophic history of the entire area. Detailed mapping was largely confined to the areas underlain by Luning and

\footnotetext{
1i Idem, pp. 1S-22 : fig. 1.
} 
later Mesozoic formations in the ranges bordering Soda Spring Valley (pl. 2), in a small part of the Paradise Range (pl. 11), and in the Shoshone Mountains (pl. 12). Elsewhere, except for small areas in the (iillis Range (fig. 2). ('andelaria Hills (figs. 7. A. 9), Monte Cristo Range (fig. 10), and Toyabe Range (pl. 15), the investigation was of a recommassance nature, and the geologic mapping was recorded on the $1: 250,000$ topographic maps.

First the western ranges, underlain principally by the Excelsior formation and granitic rocks, are described, next the ranges underlain mainly by the Luning and later formations; and finally, the ranges outside the Luning embayment-the Excelsior Mountains, the Candelaria Hills, Miller Mountain, and the Monte Cristo Range on the south, and Lone Mountain and the San Antonio, Toquima, and Toyabe Ranges on the southeast and east.

\section{WASSUK RANGE}

The Wrassuk Range, in the western part of the $\mathrm{Haw}_{\mathrm{W}}$ thorne quadrangle (pl. 1), extends east of south for a distance of 50 miles from a point just north of the edge of the quadrangle nearly to the souther'n border. On the east a steep scarp cut by narrow canyons faces Walker Lake. The highest point of the range, Mount Grant, 11,303 feet in altitude, is less than o miles from the edge of Walker Lake, which is a little more than 4,000 feet above sea-level; and the 9,000-foot contour at one point is only 2 miles from the lake. The western slope of the range toward the valley of Walker River is much less steep.

The pre-Tertiary rocks of the Wassuk Range consist of granitic types nutruded into the Excelsior formation. The more or less continuous outcrops of granitic rocks westward to the Sierra Nevada indicate that the granitic rocks of the Wassuk Range lie within the Sierra batholith, close to its eastern margin.

'The Excelsior formation is present only as irregular' roof pendants, some of which mav reach a maximum thickness of thousands of feet. Greenstone and fe!site and associated tuff and breccia make up 90 percent or more of the formation: but schist, argillite, quartzite. and a little crystalline limestone, are present in some places. No sedimentary rocks referable to the Iaming formation were recognized, but the Luning is probably. present in the Yerington district, a few miles west of the northern part of the range.

The many varieties of intrusive rocks range from diorite through granite to alaskite, granodiorite and quartz monzonite being most abundant. Two or more periods or stages of intrusion may be represented. for in certain areas granitic rocks are intruded by later rocks of the same greneral composition.
No structural data are available concerning the preTertiary rocks of the range itself, but the Excelsior pendants may be a part of the same thrust block that forms the greater part of the Gillis Range.

Tertiary and Quaternary faulting has blocked out the entire range but is most conspicuous in the southern part, particularly southward from the vicinity of the naval munitions depot west of Hawthorne, where welldeveloped scarps cross alluvial fans at the mouths of the canyons. Along most of the range front the prevailing trend of faults is north-northwest, but at the southern end the Tertiary and later faults strike north and northnortheast. On the west slope of the range there are locally north-striking fault contacts between the granitic rocks and the 'Tertiary formations but the topographic expression is less marked, and the faults are probably less continuous than along the eastern front. Although the Tertiary and Quaternary faulting may be controlled by the position of the granite contact on the eastern front, positive evidence is lacking. There is no evidence of major shearing along the western front of the range or in the valley now occupied by Walker Lake.

\section{GILLIS RANGE}

The Gillis Range (pl. 1; fig. 2), lies east of the Wassuk Range. Pre-Tertiary rocks are exposed along the crest and western flank, southeastward to the point where the range joins the Gabbs Valley Range north of the westem part of Soda Spring Valley. The Excelsior formation underlies the northern and central parts of the range and is thrust eastward over the Luning along the Gillis thrust. In the southeastern part of the range there are two large granitic masses.

The geology of most of the range is known only from reconnaissance. A small area on the eastern flank of the main range was studied in detail (fig. 2 ).

\section{ROCKS EXPOSED}

The Excelsior formation in the northern part of the range consists largely of felsite and felsite breccia and subordinate amounts of greenstone and contains small lenses of sandstone. slate, and limestone, one of which rielded cieterminable fossils of Middle Triassic age. The total thickness may exceed 10,000 feet. Elsewhere in the range greenstone is present in relatively larger amount; but the proportion of felsitic lavas seems to be greater than in other ranges, whereas chert, though present in some places, is subordinate in amount. The greenstone of the Excelsior also underlies a small area in the southeastern part of the range.

The Luning formation below the thrust is largely crystalline limestone, but it contains some slate. Fossils, together with the lithologic character, indicate a facies like that of the limestone unit of the Luning for- 


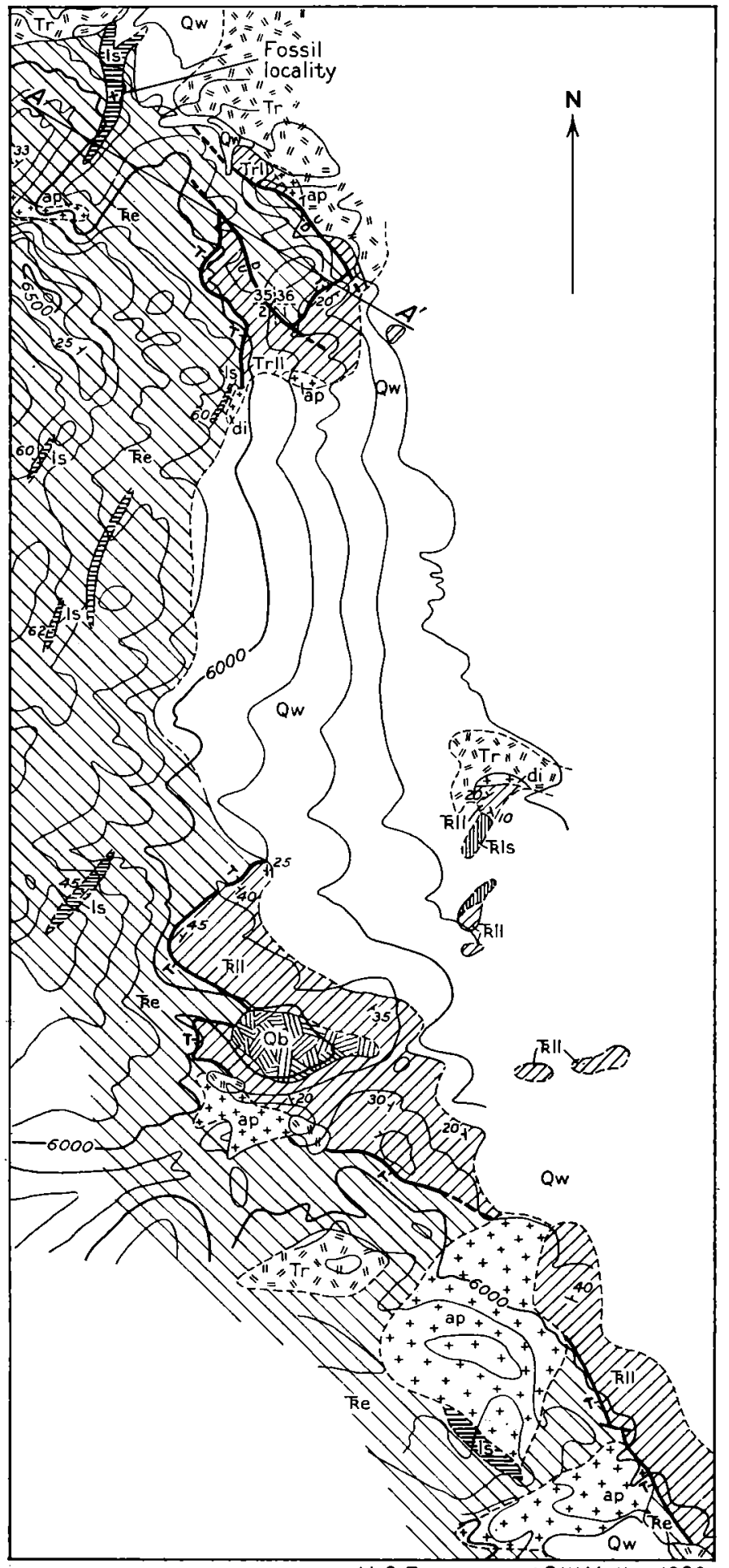

H. G. Ferguson and S.W. Muller, 1936
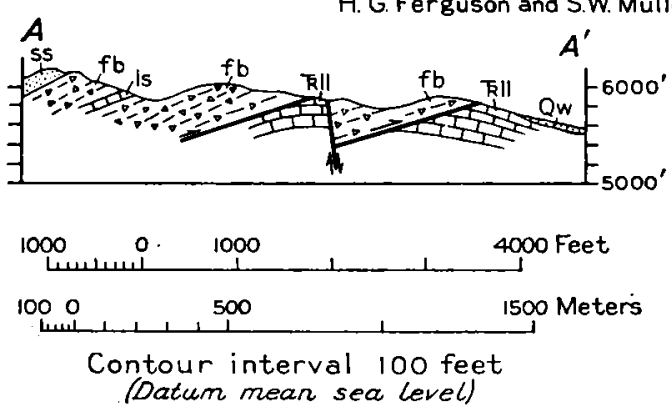

EXPLANATION
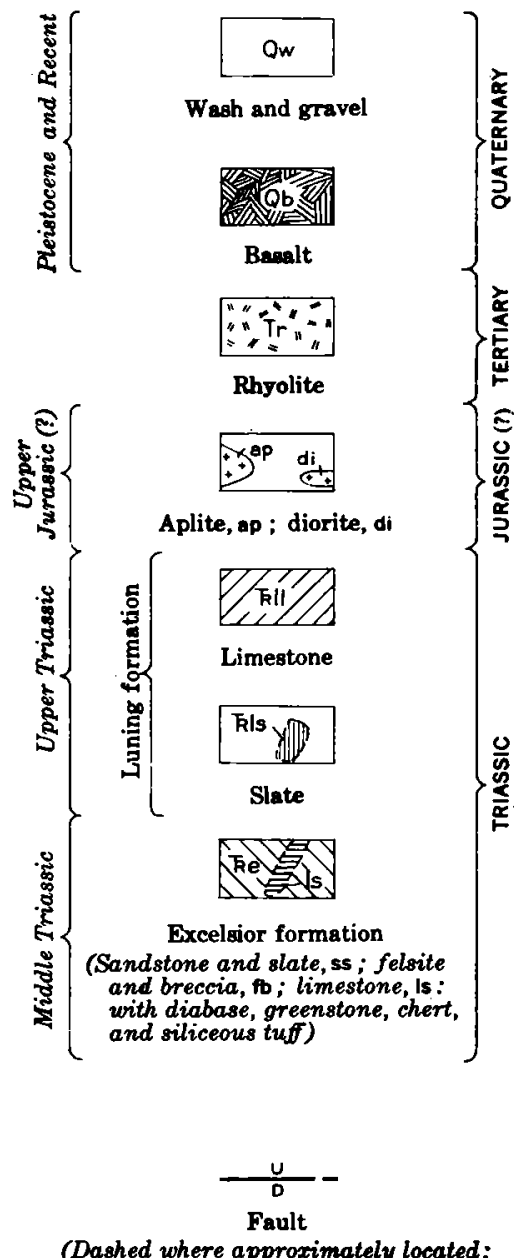

U, upthrown side; $D$, dowonthrown side)

$$
\begin{gathered}
\frac{5}{\text { Thrust fault }} \\
\text { (T, overthrust side) } \\
\text { Strike and dip of beds }
\end{gathered}
$$

FIGURE 2.-Geologic map and section of part of the Gillis Range, showing outerop of Gillis thrust. 
mation in the Gabbs Valley Range. The Gabbs and Sunrise formations also are present below the thrust near the north end of the range. The Dunlap formation, consisting of sandstone and conglomerate, is found in small areas in the extreme southeastern part of the range, where it unconformably overlies both Excelsior and Luning.

Intrusive granitic rocks occupy a large area, and nearly everywhere the older rocks are much altered. The largest mass in the southeastern part of the area seems to have been intruded along the plane of the Gillis thrust, and farther north small aplitic intrusives also follow the thrust plane.

\section{STRUCTURE}

Gillis thrust.-The major structural feature of the range is a thrust striking northwestward that brings the Excelsior above the Luning and the northern part of the range, also over the Gabbs and Sunrise formations (pl. 1). The thrust plane is again exposed farther south, southeast of Gillis Canyon (fig. 2). The outcrop there can be followed along the east flank of the range near the head of Ryan Canyon. The thrust dips gently to the soithwest. Southeast of Ryan Canyon diorite and granodiorite separate the Excelsior and Luning formations and were evidently intruded along the thrust plane. What appears to be the same thrust crops out in the northwestern part of Garfield Hills. (See p. 24.)

As far as observed, the Excelsior of the upper plate dips to the west and northwest and is not folded. The Luning of the lower plate is broadly folded but not overturned. Over most of the area the general trend is northwesterly but near the head of Ryan Canyon the Luning strike is northeasterly.

At the southeastern end of the range Excelsior is also present in the lower plate, overlain by both Luning and Dunlap. All the rocks are there highly metamorphosed and relations are obscure.

Tertiary normal faults.--Tertiary faults with prevailing northwesterly strikes are present in places throughout the range but the only prominent fault scarp is that which bounds the southwestern side of the ridge that enters the valley 7 miles northwest of Luning. This fault may have a throw of several hundreds of feet near Soda Spring Valley, for Pliocene (?) andesite is present on its downthrown side. Although the position of a steep canyon in the southern flank of the range was determined by the fault, it cannot be recognized in the upper part of the canyon nor does it cross the low ridge that forms the crest of the range. The displacement, therefore, must be essentially vertical, dying out abruptly at the northwest.

\section{GARFIELD HILLS}

The Garfield Hills (pl. 2) lie north of the Excelsior Mountains and are bounded on the north and east by Soda Spring Valley and on the west by Whiskey Flat and the southern end of Walker Lake Valley. Pleistocene basalt and Tertiary andesite and rhyolite cover a large part of the western half of the range, and the recent deposits of Garfield Flat and neighboring valleys conceal the structure of much of the central and southern parts. Although the older rocks underlie large areas in the eastern, central, and northwestern parts, several masses of intrusive granitic and aplitic rocks are also present, and the individual areas of unaltered Mesozoic sedimentary rocks are smaller than in the Pilot Mountains and Gabbs Valley Range. The area that includes the outcrops of pre-Tertiary rocks is a belt roughly 25 miles from east to west by 10 miles from south to north. Different parts of the area reflect essentially all the episodes of the Jurassic orogeny, early thrusting and folding in part contemporaneous with Dunlap deposition, in the east, and later larger scale thrusting, involving thrust slices of the Excelsior formation, in the west.

\section{ROCKS EXPOSED}

Excelsior formation.--The Excelsior bordering the southern margin of the Luning Embayment crops out at the southeast and southwest ends of the area. In the southeastern part the Excelsior exceeds 5,000 feet in thickness and consists of chert, cherty tuff, and includes about 1,000 feet of dark tuffaceous sandstone in the lower part. At the southwest end of the range greenstone and greenstone breccia are the principal rocks, but chert and cherty tuff apparently underlie the greenstone.

The Excelsior bordering Soda Spring Valley between Mina and Luning is largely greenstone and breccia and contains several basic intrusive masses, and near the northern margin a small amount of interbedded chert and tuff. The isolated areas of Excelsior in the vicinity of Garfield Peak consist of felsite, felsite breccia, and greenstone.

In the higher thrust plates, which overlap the earlier structures at the western end of the range, the Excelsior contains a larger proportion of felsitic lava, though greenstone and greenstone breccia are also abundant.

Luning formation.-All the structural units of the Garfield Hills except the upper plate of the Gillis thrust include outcrops of the Luning formation. Three divisions-a lower slate and conglomerate unit, a limestone unit, and an upper slate unit-are distinguished on the geologic map (pl. 2).

The lower slate unit is largely brown siliceous slate containing varying amounts of conglomerate, most abundant near the base. In the southeastern part be- 
HAWTHORXE AND TONOPAH QUADRANGLES, NEVADA

low the Garfield thrust, the slate member contains a large proportion-in places perhaps as much as 30 percent-of coarse conglomerate composed of angular boulders of chert from the Excelsior formation suggesting proximity to the margin of the embayment. Elsewhere, especially in the higher thrust plates of the southwestern part, only a little conglomerate is present. The thickness of this unit also varies greatly, exceeding 1,000 feet in the lower thrust plates of the marginal area and ranging from less than 50 to about 300 feet in the higher thrust plates.

The limestone unit of the Luning crops out in all the structural units below the Gillis thrust, but it shows no distinctive features in the different thrust plates. The total thickness probably exceeds 2,000 feet, but no section is complete.

Dolonite is found sporadically in the limestone unit but is probably largely the result of secondary alteration, and there is no massive dolomite, such as forms the upper member of the formation in the Gabbs Valley Range a few miles to the east. The Gabbs formation directly overlies limestone in the northwest and southwest.

The upper slate unit lies within the limestone and may not be at the same horizon in all parts of the range, but these slate beds in places reach a mappable thicknéss (pl. 2).

No complete section of the Luning is present in any one thrust plate, and its thickness is indeterminable; but a combination of the different partial sections suggests a thickness of slightly more than 5,000 feet, which is less than the average thickness of the formation.

Gabbs and Sunrise formations.-The Gabbs and Sunrise formations consist of thin-bedded slaty limestones and slates, essentially similar to those of the type areas in the Gabbs Valley Range.

Dunlap formation.-The Dunlap formation crops out in all of the structural units below the McGee thrust and in each shows a widely varying lithologic character.

The Dunlap which rests directly on the Excelsior, below any known thrust (secs. $B-B^{\prime}, C-C^{\prime}$, and $F-F^{\prime}$; pl. 2), includes a lower sedimentary unit which consists dominantly of red sandstone but contains a variable amount of conglomerate, particularly at or near the base, and one or two beds of marine limestone; and an upper volcanic unit composed of greenstone, greenstone breccia, and interbedded sandstone. The total thickness may be about 4,000 feet of which the upper 2,000 feet contains principally volcanic rocks.

The Dunlap formation in the trough north of Garfield Flat (fig. 3) overlies both Luning and Excelsior unconformably (secs. $C-C^{\prime}, D-D^{\prime} ; p^{\prime} .2$ ), and in the southern part of the area, northwest of Garfield Flat, orerlies the Sumrise formation with apparent conformity. The major part occupies a syncline with Excelsior on the south and Luning on the north. Dumlap is also present in synclines superposed on the folded Luning. The maximum thickness may be as much as 3,000 feet.

The lithologic character is highly varied, and individual berls cannot be matched on opposite sides of the major syncline, with the exception that a thin bed of impure gray limestone borders the Excelsior contact, and a part of the contact with the Luning formation. Above this limestone on the southern limb of the syncline, the Dunlap is largely red sandstone in part crossbedded. The upper part contains a few beds of limestone conglomerate, but the bulk of the material could have been derived from the Excelsior.

Near the trough of the syncline, there is an andesitic lava flow with prominent square feldspar phenocrysts, lut the Dunlap in this area does not contain the great thickness of volcanic rocks present in the south western Garfield Hills and the neigboring Gabbs Valley Range. The lava flow is of uneven thickness and absent in some places.

On the north limb of the syncline the Dunlap consists largely of limestone fanglomerate and conglomerate and has a maximum thickness of at least 1,000 feet. At the base, large angular blocks of limestone from the Luning formation grade upward into a roughly bedded conglomerate composed of partly rounded limestone pebbles. The outliers of Dunlap resting on the Luning are principally limestone fanglomerate and conglomerate interbedded with a little slate and sandstone.

North west of Garfield Peak, above the Marble Quarry thrust, the Dunlap is conformable on the Sunrise. The formation here consists essentially of red sandstone and slate with several limestone beds and minor conglomerate.

The varied lithology of the Dunlap is of some structural significance. Along the southern margin of the area, where there is no major folding, the lower sedimentary portion is succeeded by volcanic material. In the trough east of Garfield Peak deposition of the lower sandy member of the Dunlap overlapped both the Excelsior and Luning formations, but at the southwest end of the trough Dunlap was deposited conformably on the Sunrise, and there is a similar conformable contact to the west, above the Marble Quarry thrust, suggesting that early folding was confined to this trough. The sharp change in the northern area from sandstone to coarse fanglomerates derived from the Luning indicates the beginning of local intense folding. That this intense folding was essentially confined to the area bordering the trough in which the fanglomerate was deposited, is indicated by the small areal extent of the fanglomerate. The stratigraphic position of the fanglomerate with relation to the lava flow suggests that this local intense folding was contemporaneous with rolcanism in other parts of the area. 
Intrusive rocks.-The larger masses are coarsegrained and include granite, quartz monzonite, granodiorite and diorite. Large dikes of gabbro cut the Luning formation in the western part of the northern area. Aplite is widespread; commonly it forms narrow dikes along the thrusts and sills in the thin-bedded Gabbs and Sunrise formations and the slate members of the Luning. Sizeable masses of aplite also intrude the Dunlap and Excelsior formation. Except for moderate doming by the aplite masses in the west, the emplacement of the intrusive bodies does not seem to have affected the structure of the invaded rocks. The preexisting thrusts, however, appear in some places to have determined the present position of the granitic masses.

\section{STRUCTERE}

The varied structures in the Garfield Hills epitomize the entire sequence of the Jurassic orogeny. Prior to the deposition of the Luning, the Excelsior formation was folded. In part at least the movement was directed to the north as shown in the overturned fold in the chert of the Excelsior west of Mina (sec. $F-F^{\prime}$, pl. 2 ) ; elsewhere, angular unconformities separate the Excelsior and later formations, but the direction of early folding is not determinable. The lithologic character of the Luning formation below the McGee and Pamlico thrusts indicates near-shore deposition, and the southern border of the Luning probably was not far from the present margin of the formation. The mass of the Excelsior formation within the embayment, between Garfield Peak and Soda Spring Valley, may have persisted as an island during a part of Luning sedimentation or may have been uplifted and its cover of Luning eroded prior to the deposition of of the Dunlap formation.

The Dunlap formation appears to have been deposited first in a broad marginal basin, following roughly the border of original Luning deposition; but a later more restricted depression north of the original contact formed a trough into which were poured the conglomerates and fanglomerates derived from the rising folds of the Luning. Elsewhere in the area volcanoes were active during the initial stages of Jurassic folding while the fanglomerate of the upper part of the Dunlap formation was being deposited.

This area of early folding, including the Dunlapfilled trough and the adjoining terrain, presumably was uplifted after the early folding and impeded and deflected the later folds and thrusts, as the folds on the south flank of Garfield Peak trend northeastward and are locally back-folded and thrust to the northwest (pl. 2 , sec. $\left.C-C^{\prime}\right)$. The direction of the thrusting that followed the early folding was dominantly southerly. The interior mass of the Excelsior formation, which borders the folded area east of Garfield Peak, is itself thrust over Luning, which is in turn thrust orer the marginal Excelsior in the southeast corner of the area along the Garfield Flat thrust.

The position of the thrusts that border the folded area and the presence of the steeply dipping segment of the Marble Quarry thrust (fig. 5) suggest that these thrusts were deflected by the intensely folded rocks and, like the East Ridge thrust of the Pilot Mountains (p. 36), moved along a combination of gently and steeply dipping planes.

In the southwest corner of the area, irregularities of the marginal Excelsior may have influenced the trend of early folding and thrusting.

The Ashby thrust (pl. 2) has carried Luning and strongly folded Gabbs and Sunrise formations to the southeast above the Excelsior. The incompetent Sunrise formation, thus crowded against the resistant Excelsior, was closely folded, but the Luning was broken along small thrusts. Similarly, the marginal Excelsior of Bromide Canyon caused the folds to be bent northwestward and to be overturned and thrust southwestward.

Two higher thrusts, the McGee and Pamlico (pl. 2), differ from the lower thrusts in that their planes cut into the Excelsior formation, though not deeply, as Luning is also present in the upper plates.

The highest thrust, which is exposed only in the northwest part of the range, contains a much thicker section of the Excelsior formation on the upper plate and is regarded as the southward extension of the Gillis thrust, which crops out along the eastern flank of the Gillis Range (p. 16 ; sec. $A-A^{\prime}$ pl. 2 ; fig. 2 ).

Pre-Jurassic Folding.-Structure within the Excelsior could be worked out with assurance only along the ridge bordering Soda Spring Valley. Here a bed of tuffaceous standstone in the chert is folded into two anticlines with overturn to the north (sec. $F-F^{\prime}$ pl. 2 ) the northern overlain by Bunlap with moderate northerly dip.

The Excelsior to the north, adjoining the Dunlap trough (fig. 3), at one point contains chert which strikes northwestward and dips about $75^{\circ} \mathrm{SW}$., whereas the overlying Dunlap strikes northeastward and dips $60^{\circ}$ NW. To the north, where the Dunlap overlies the Luning unconformably, the greatest observed angular discordance is about $20^{\circ}$.

At the restern end of the area northwesterly trends in the folds of the marginal Excelsior may have influenced later structures.

Early folding of Luning formation.-The first folding of the Luning formation was localized by a trough in which the upper conglomeratic portion of the Dunlap was deposited. This trough was not at the margin of the Luning embayment, as in the Pilot Mountains. but bordered an interior mass of Excelsior. As this 

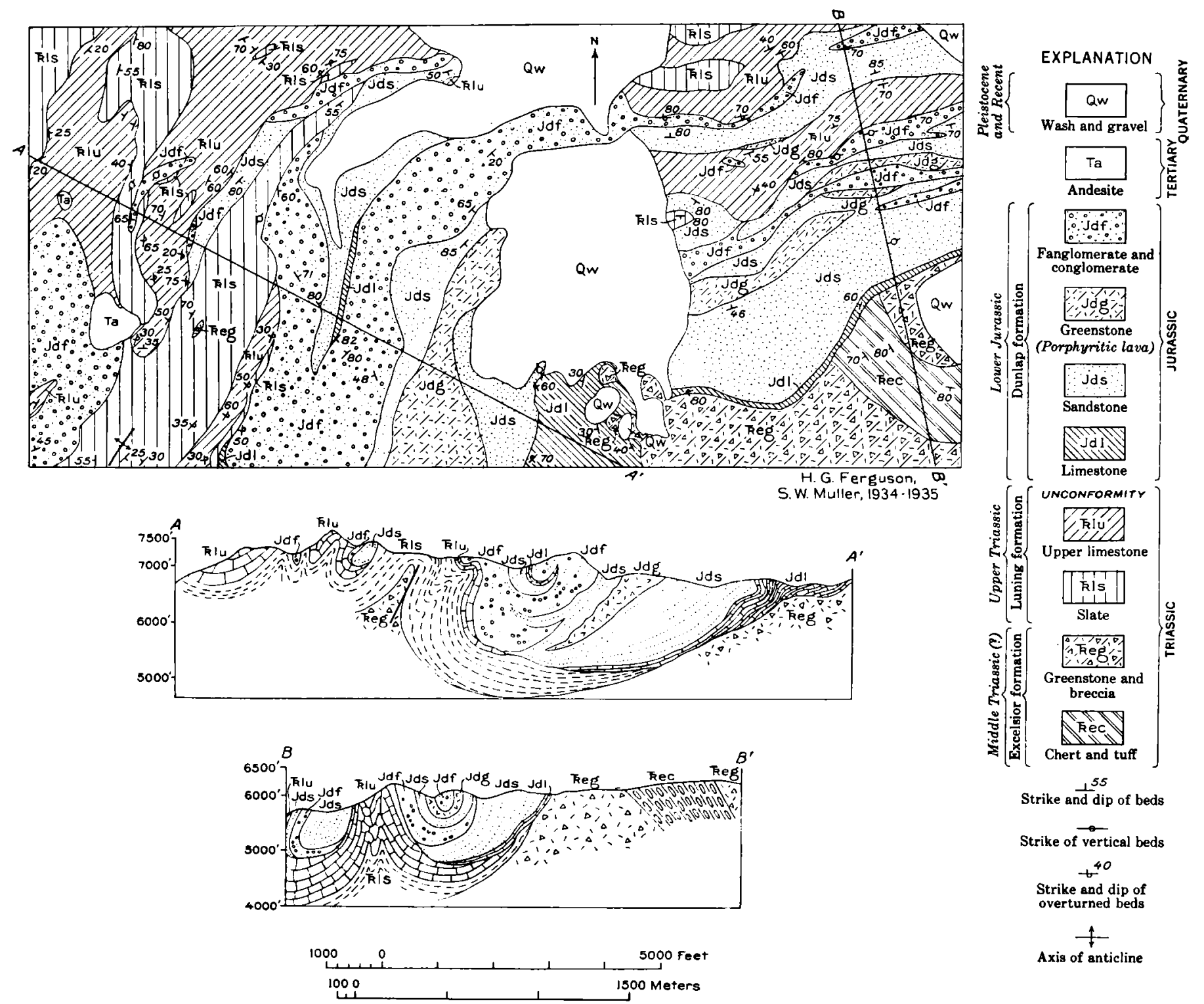

Figure 3.-Geologic map and sections of area north of Garfeld Flat, showing relations of Dunlap formation to Luning and Excelsior formations.

trough developed, the rising folds in the Luning yielded the thick fanglomerate and conglomerate that comprise the upper part of the Dunlap in the area. During this stage, deposition extended north and west, and conglomerate of the Dunlap formation lies on the truncated folds previously formed in the Luning and overlaps both the limestone and slate. (See pl. 4A; fig. 3.)

The folds bordering the Excelsior west of Soda Spring Valley trend eastward and are overturned southward (secs. $E-E^{\prime}, F-F^{\prime}, \mathrm{pl} .2$ ), and there is a small southward thrust on the eastern ridge. Locally, however, the Dunlap along the Excelsior contact is overturned to the north.

This trough must have been of relatively small extent for to the southwest, west of Garfield Flat, Dunlap overlies the Sunrise formation conformably. (See sec. $B-B^{\prime}$, pl. 2 ; fig. 5.)

Minor southward thrusting (pl. 2, sec. $F-F^{\prime}$ ) may have accompanied or closely followed this folding.

Garfield Flat thrust.-The thrust or group of thrusts, here called the Garfield Flat thrust (fig. 4), is thought to have carried the folded Luning and Dunlap formations southward toward the margin of the Luning embayment. On the ridge west of Mina, this thrust, which brings slate of the Luning formation above the Excelsior and Dunlap, has a gently undulating plane striking in general north of east and dipping $20^{\circ}-30^{\circ}$ northward. The slate of the upper plate is gently folded and dips prevailingly northwestward. North of the outcrops of the granite, the limestone and upper slate of the Luning are sharply folded and overturned 
to the south, and the mass of greenstone in the Excelsior formation to the north is thrust against the Luning on a plane dipping steeply to the north.

It seems probable that the Garfield Flat thrust carried the earlier folded rocks of its upper plate southward to the marginal Excelsior. If so, the southward thrust of the inner mass of Excelsior against Luning on the upper plate of the Garfield Flat thrust (sec. $F-F^{\prime}$, pl. 2) may be older than the Garfield Flat thrust.

The Luning slate of the lower plate contains coarse conglomerates of chert pebbles, suggesting that it has not moved far from the contact with the Excelsior formation. The Dunlap formation is present on both plates of a subordinate lower thrust (fig. 4). Below this thrust are sandstone, conglomerate, and volcanic rocks probably resting on the Excelsior to the south, though the contact is concealed.

On the ridge east of Garfield Flat (fig. 4), the Garfield Flat thrust carries Luning limestone and Dunlap on its upper plate. The thrust plane strikes northeastward and dips gently northwestward. Klippen of limestone of the Luning rest on the greenstone of the Dunlap half a mile to a mile southeast of the outcrop of the thrust plane. The thrust overrides a subordinate thrust, which brings the slate unit of the Luning above the same mass of Dunlap.

In the Dunlap that overlies the slate and conglomerate of the Luning to the north, below the Garfield Flat thrust, the conglomerate contains limestone pebbles of the Luning as well as chert of the Excelsior, thereby suggesting deposition after folding started and perhaps during thrusting.

In this area the Dunlap formation crops out over nearly the entire upper plate of the thrust, but immediately above the Garfield Flat thrust is limestone of the Luning formation, missing in places, and nowhere more than 200 feet thick.

The contact of the Dunlap and Luning in the upper plate is highly irregular, in part owing to erosional unconformity, but probably also the result of minor thrusting above the plane of the major thrust.

On this ridge the Garfield Flat thrust shows a definite thrust contact of the Luning formation over granodiorite. This contact can be traced northeastward along a front of about 1,500 feet (fig. 4). At the crest of the ridge, where the contact bends abruptly

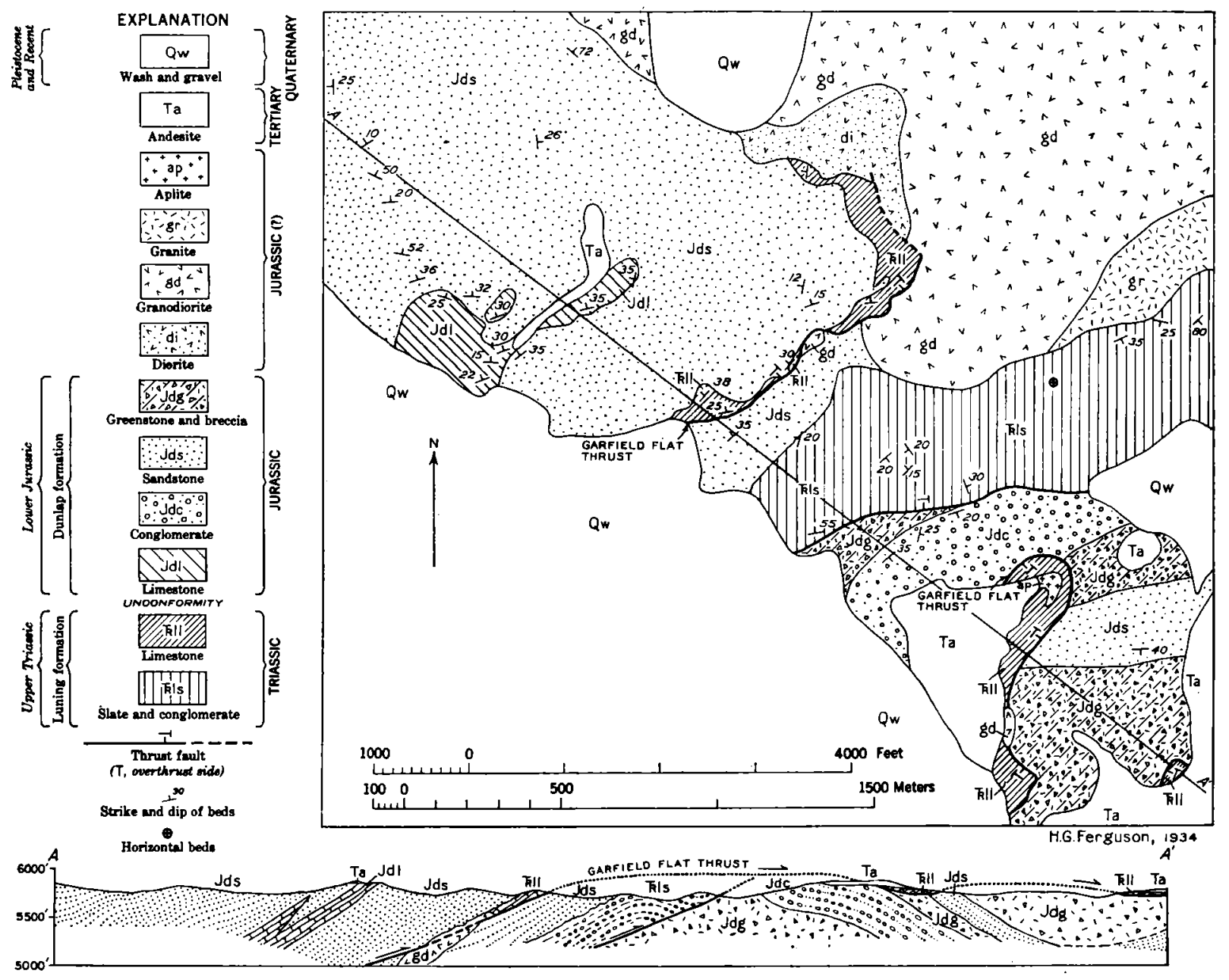

FIgURe 4.-Geologic map and section of a rea east of Garfield Flat showing outcrop of Garfield Flat thrust. 

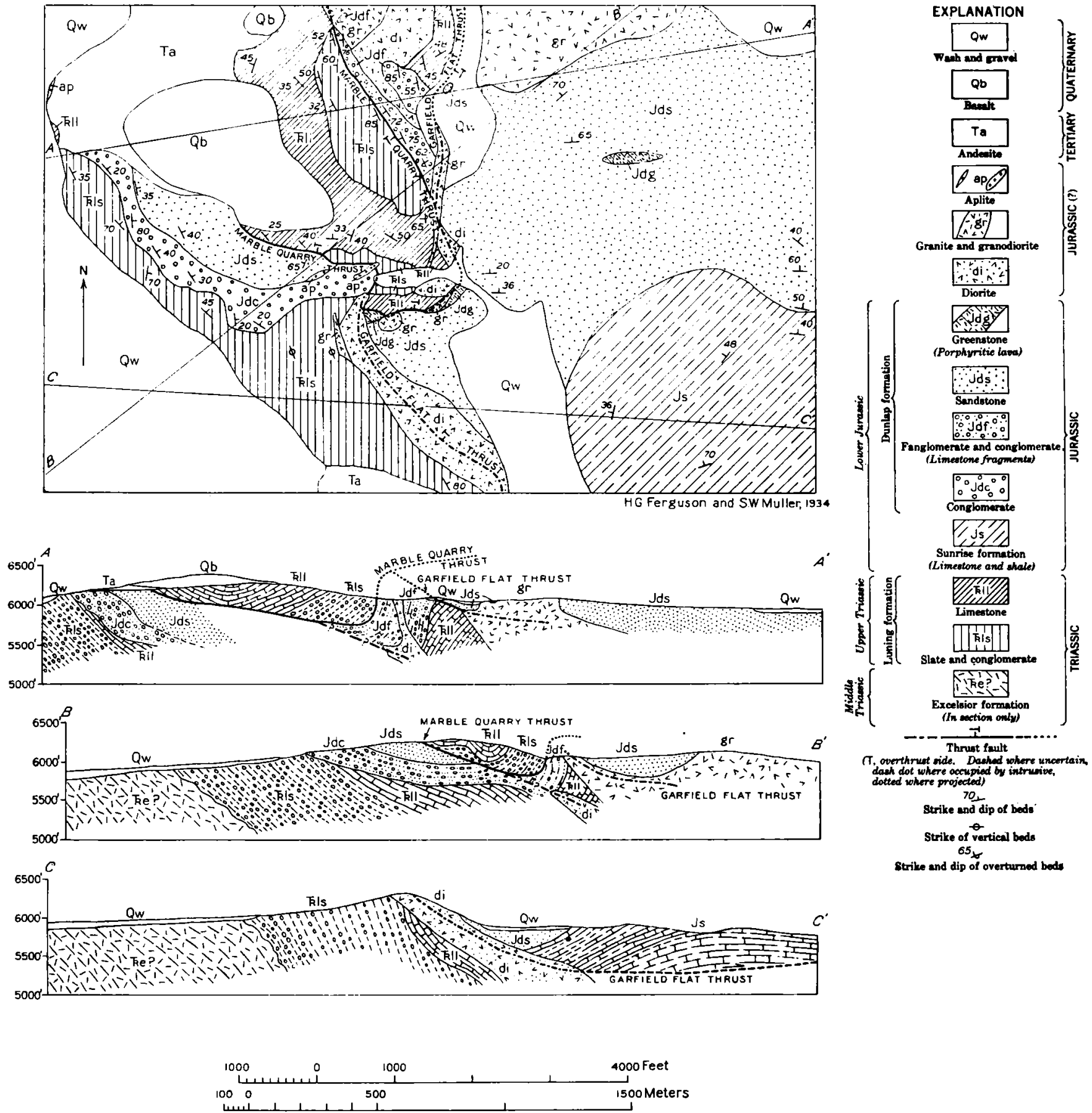

Figure 5.-Geologic map and sections of area northwest of Garfiel d Flat, showing relations of Marble Quarry and Garfield Flat thrusts.

to the northwest, its nature is in doubt; but 1,000 feet farther north diorite and granodiorite intrude the limestone and the overlying Dunlap. These relations are most easily explained by assuming that the intrusion followed the plane of the thrust and that later renewed pressure, perhaps growth of the intrusive body itself, locally produced minor movement.

The Garfield Flat thrust is also present in the low hills northwest of Garfield Flat (sec. $B-B^{\prime}$, pl. 2; fig. 5). Here its outcrop is concealed by wash and ob- scured by dikes of granodiorite and diorite, which follow the thrust plane, but its existence is indicated by the dissimilarity of the rocks on either side. It it: northern end the thrust is cut off by a mass of alaskite; but just to the south, in the wash east of the basaltcapped hill, the red sandstone of the Dunlap, which further south overlies the Sumrise formation, crops ont close to limestone of the Iuning formation (fig. 5). For a short distance the Garfield Flat thrust is orerlapped by the klippe of the Marble Quarry thrust, but 
southeast of the hill, a southenstward-trending dike of diorite is intruded along the thrust, separating the slate of the Luning formation on the west from the Dunlap overlying the Sumrise.

The Sunrise and overlying Dunlap formations of the upper plate have homoclinal northerly to north westerly dips near the thrust. To the northeast several folds in the Dunlap trend east, but the structure cannot be worked ont in detail.

There may be another thrust whose outcrop is concealed by the klippe of the Marble Quarry thrust, for the rocks are different on opposite sides of the klippe. (See secs. $A-A^{\prime}$ and $B-B^{\prime}$, fig. 5.) On the northeast, limestone of the Luning formation is overlain unconformably by a basal Dunlap fanglomerate containing large fragments derived from the underlying Luning limestone (pl. $4 B$ ). On the opposite side of the hill, less than 2,000 feet distant, the Luning consists of slate containing a single lava flow near the top and very little conglomerate. The lower part of the overlying Dunlap formation consists of conglomerate composed of pebbles of slate and lava but lacking limestone (pl. $4 C$ ). Above the conglomerate is red sandstone and sandy slate with lenses of conglomerate.

Uplift and change in trend of folding.-Uplift of the earlier folded area is believed to have caused deflection of the later folds and local back-folding. The ensterly trend of the folds near Soda Spring Valley south of Luning changes to northeast on the ridge to the west; and the infolded Dunlap, striking essentially parallel to the underlying Luning in the eastern part, here overlies the truncated limestone and slate of the Luning. The southernmost folds are mostly overturned to the southeast; but farther northwest in the vicinity of Garfield Peak, the direction is reversed and folds are prevailingly overturned to the nortliwest. Small thrusts that border the exposed Excelsior of this region apparently do not continue far into the Luning but merge into folds in the more pliable sedimentary rocks above the Excelsior (secs. $C-C^{\prime}, D-D^{\prime}$, pl. 2).

The back-folding in the Garfield Peak region cannot be the result of the intrusion of the granodiorite mass to the southeast, for the Dunlap near the contact dips toward the intrusion and the nearest folds are overturned towards it.

The change in direction of overturn is similar to that in the northwestern Pilot Mountains, where the folds trending westward and overturned southward near Soda Spring Valley veer to the northwest and are locally overturned northeastward within a short distance to the east.

Marble Quarry thrust.-The area of early folding is orerlapped by a thrust that crops out north of Garfield Peak and that may be a segment of the Marble Quarry thrust of the southern Garfield Hills, northwest of (rarfield Flat (pl. 2). The folds directly above this thrust are approximately symmetrical and trend a few degrees west of north, in contrast to the northeasterly trend in the lower plate. The Dunlap formation here overlies the upper slate unit of the Luning.

The isolated area of pre-Tertiary rocks on the north flank of the range northwest of Garfield Peak (pl. 2) is probably part of the upper plate of the same thrust. 'The formations exposed include the upper limestone and upper slate units of the Luning, the Gabbs, and Sumrise formations, and the Dunlap, which is here conformable on the Sunrise. These crop out in a syncline that trends a few degrees north of east and is in part overturned to the north. On the western part of the north limb, this syncline is complicated by several transverse corrugations, the westernmost very sharp and broken by a small fault. 'Toward the east the syncline is compressed from both north and south and broken by small thrusts. On the north limb of the syncline the thrusting is within the Dunlap, but on the south limb, the limestone and upper slate units of the Luning are thrust northward over the Dunlap.

The continuation of this thrust crops out at the marble quarry northwest of Garfield Flat. Here dolomitized limestone of the Iuning formation is thrust orer sandstone of the Dunlap. The thrust here strikes about east and dips gently northward. Folds in the limestone of the upper plate trend east of north.

A mile to the south (fig. 5) is a klippe of the same thrust. The thrust plane that carries the Luning over Dunlap is well exposed for a short distance at the south end of the hill. Here the strike is west-northwest, and the plane dips gently to the north. But on the northeast side of the hill the fault contact of Luning and Dunlap has a north-northeast strike and apparent steep dip. The dips in the slate of the Luning on the west are steepest near the fault. It is believed, however, that this steep fault is a part of the same thrust plane because the fault camnot be traced south of the outcrop of the gently dipping segment.

The Marble Quarry thrust, therefore, may follow a combination of steep and gentle planes, the lowest flat segment being farthest away from the uplifted area of earlier folded rocks to the northeast; or the change in dip may be due to local folding of the thrust plane in the same direction, as is suggested by the steeper dips in the rocks on both plates near the steeply dipping segment.

Both the slate and overlying limestone of the klippe are folded. The major structure appears to be a syncline whose axis trends west to northwest. This fold is overturned to the north at the southeast end.

Ashby thrust.-In the western part of the Garfield Hills there is a succession of overlapping thrusts. The higher of these carry slices of the Excelsior above the 
Luning and younger formations. The lowest of the group, the Ashby thrust, carries highly folded Luning and Sunrise against the Excelsior formation at the south margin of the embayment. The Ashby thrust (secs. $A-A^{\prime}$ and $B-B^{\prime}$, pl. 2) may represent movement of considerable magnitude, for on the lower plate Dunlap rests on the Excelsior, whereas on the upper plate Dunlap overlies Sunrise. The conglomerate in the Dunlap formation above the Excelsior near the thrust contains limestone pebbles from Luning formation. Therefore, the Ashby thrust may be a surface thrust that has overriden the contact of Luning and Excelsior, and the relatively steep dip of the eastern segment of the thrust may be the result of later uplift of the marginal Excelsior. The Ashby thrust, like the Garfield Flat thrust, carries the folded formations of the Luning embayment southward to its southern margin; and, as in the upper plate of the Marble Quarry thrust, the Dunlap of the upper plate rests on the Sunrise formation. It may be the western segment of either thrust.

To the west near the head of Bromide Canyon, along the western segment of the Ashby thrust, Luning overlain by the Gabbs and Sunrise formations is thrust over Luning that overlies the Excelsior unconformably.

The upper plate of the Ashby thrust contains closely folded rocks. The thin-bedded Sunrise formation, which crops out at the head of McGee Canyon, is pressed into tight folds generally striking northeastward and overturned southeastward. Conglomerate of the Dunlap formation, whose pebbles are derived from the underlying limestone of the Sunrise formation, orerlies the Sunrise without apparent angular unconformity.

The higher thrust, which in part overlaps the eastern segment of the Ashby thrust, is interpreted to be the result of rupture of an overturned anticline in the closely compressed area below the McGee thrust. (See sec. $A-A^{\prime}$, pl. 2.)

'To the west the strike of the folds changes to northwesterly. The folds in the Luning between Neversweat and Bromide Canyons parallel the outcrop of the Ashby thrust, which overlaps the marginal Excelsior in Bromide Canyon. In contrast to the close folding in the part of the area underlain by the Sunrise, several of the folds that involve the Luning are broken by small thrusts, and the outcrop of the overlying Gabbs formation is in part concealed by thrusts, suggesting that the more massive Luning yielded by fracture and that the thrusts died out in folds in the incompetent Sunrise.

McGee thrust.-The McGee thrust is the lowest of the group of large flat thrusts that have cut into the basement and carried slices of the Excelsior above the sediments of the Luning embayment. The thrust crosses the ridge between Neversweat and McGee Canyons, but is cut by an intrusive mass of aplite west of Neversweat Canyon. The average strike is easterly, and the observed northerly dip is nowhere more than $25^{\circ}$.

The structure of the upper plate is obscured by the klippen of the higher Pamlico thrust and by intrusive aplite. Excelsior lavas form the southern part of the upper plate; near the outcrop of the thrust, felsites predominate, but to the north, below the Luning, the Excelsior consists entirely of greenstone. The folds in the Luning formation of the upper plate trend to the northwest and are steepest in the western portion.

Probable major movement on the McGee thrust is suggested not only by the fact that the thrust plane has cut deeply into the Excelsior but also by the slight thickness of the lower slate and basal conglomerate in the Luning as compared with the section in the lower thrust plates, suggesting an offshore facies of the Luning. The lower slate unit of the Luning in the upper plate nowhere exceeds 300 feet in thickness and is locally absent.

Pamlico thrust.-The Pamlico thrust is found only in klippen. The confused appearance of the geologic map in the area immediately north and south of Pamlico Canyon is due to the fact that the thrust plate represented by these klippen is itself broken by subordinate thrusts, crusing alternations of outcrop of Excelsior and the slate and limestone members of the Luning (pl. 2, sec. $\left.A-A^{\prime}\right)$. 'These are in turn cut by two systems of normal faults.

The Luning of the upper plate is gently folded, the folds trending west and northwest. The underlying Excelsior dips much more steeply. At the south end of the southern klippe, east of McGee Canyon, repetition of a steeply dipping bed of limestone in the Excelsior suggests a steep syncline trending northwestward. North of Pamlico Canyon the Luning, dipping about $10^{\circ} \mathrm{S}$., unconformably overlies successive bands of felsite, chert, and greenstone.

North of Pamlico Canyon several minor thrusts split the klippe into thin wedges, resulting in alternating cutcrops of slate and limestone of the Luning formation. One of these thrust plates contains a thin wedge of felsite of the Excelsior, but the others carry slate of the Luning above the thrust plane, suggesting that most of these subordinate thrusts originated at the contact of the Luning and Excelsior.

Gillis thrust.-The greenstone of the Excelsior formation at the northwestern end of the Garfield Hills near Kinkaid Siding is believed to be a part of the upper plate of a major thrust, probably the Gillis thrust (sec. $C-C^{\prime}$, pl. 2), for a thrust, which carries Excelsior over Luning (sec. $A-A^{\prime}$, pl. 2), crops out to the northwest. The granitic intrusive bordering the Excelsior on the south appears to have been intruded along this thrust. 
Later normal faults.-Tertiary and Quaternary normal faults are present in some places, but these later faults are fewer than in other ranges and do not complicate the structure of the older rocks. The veins of the Garfield, Mable, and Lottie mines on the north and east slopes of Garfield Peak follow faults that may be of pre-Tertiary age but are later than the folding. The veins themselves are much faulted. None of these faults, however, is of sufficient displacement to be shown on a geologic map of the scale of plate 2. Pleistocene gravel is in fault contact with older rocks at one point north of Garfield Flat and is tilted near the fault, but the fault seems to be neither large nor persistent. The east front of the range between Mina and Luning appears to be a fault scarp though more frayed than that of the Gabbs Valley Range; consequently, it is probable that the small area of Dunlap in fault contact with the Luning formation on the eastern front of the range, $11 / 4$ miles south of Luning, is downthrown along a Tertiary fault.

The normal faults in the vicinity of Pamlico Canyon may be of Tertiary age, for they lack the aplite dikes, which occur along the thrust planes. The major normal faults along the east flank of the ridge strike north west, but some faults of small throw strike northeast. No displacement of the faults of one system by those of the other was observed.

\section{GABBS VALLEY RANGE}

The Gabbs Valley Range (pls. 2, 5; fig. 6) lies east of the central part of Soda Spring Valley. Its western front is essentially continuous with the Gillis Range on the northwest and with the Pilot Mountains on the south. The range is largely underlain by Tertiary lavas, but Mesozoic rocks crop out along the western front, north and east of Luning, and extend eastward to the east front of the range at its south margin. The southernmost outcrops are only a mile distant from the exposures of Mesozoic rocks in the Pilot Mountains.

Detailed study was confined to the southern part of the range (pl. 5 ; fig. 6 ).

\section{ROCKS EXPOSED}

The pre-Tertiary rocks of the area include the upper part of the Luning formation, the Gabbs, Sunrise, and Dunlap formations, and intrusive granitic and aplitic rocks.

The Luning formation, which crops out in the upper plate of the New York Canyon thrust, is about 4,000 feet thick and consists essentially of limestone and massive dolomite. The contact is gradational and the upper dolomite unit is 800 to 1,000 feet thick. In the southeastern part of the range a bed of slate of mappable thickness may represent the lower slate unit, as the overlying limestone is the stratigraphic equivalent of the upper limestone of the Pilot Mountains. Elsewhere a few thin slate beds are present in both limestone and dolomite.

The Gabbs and Sunrise formations are lithologically similar and consist of thin-bedded shale and limestone. The Gabbs is 420 feet thick and the Sunrise 1,240 feet thick. In the detailed map of the New York Canyon area (pl. 5), each formation has been divided into smaller lithologic units.

The Dunlap formation in different parts of the range overlies all the earlier formations. It rests on the Gabbs and Luning formations with angular unconformity, on the Sunrise in one place with marked erosional unconformity and elsewhere with apparent conformity. The Dunlap formation has a maximum exposed thickness of about 5,000 feet. The lower part, 2,000 to 3,000 feet thick, consists of red standstone containing some volcanic material overlain by fanglomerate and conglomerate composed of limestone ant? dolomite pebbles from the Sunrise and Luning formations. The upper part consists largely of volcanic rocks, principally greenstone, greenstone breccia and tuff, and minor amounts of felsite and felsite breccia interbedded with sandstone and a little conglomerate.

The intrusive rocks include diorite, granodiorite, and aplite. The coarse-grained rocks transect the structure irregularly, but the aplite intruded along the New York Canyon thrust has moderately domed the surrounding rocks. A plite and dacite sills also intrude the folded Gabbs and Surrise formations.

\section{STRUCTURE}

In contrast to the intense folding in the Garfield Hills on the opposite side of the valley, the rocks are broadly folded; but they are cut by two thrusts along which movement was to the south or southeast. The lower, Sunrise Flat thrust, along which the movement was relatively small, crops out for a short distance only on the west side of Sunrise Flat and carries the Sunrise formation and lower part of the Dunlap over the upper volcanic portion of the Dunlap. The Sunrise Flat thrust is truncated by the larger New York Canyon thrust (sec. $G-G^{\prime}$, pl. 2).

The plane of the New York Canyon thrust is broken by normal faults and is in part overlapped by Tertiary lava, so that its outcrop is separated into several segments. Except at the southern outcrop in the New York Canyon area, where the Gabbs formation overlies the thrust plane, the upper part of the Luning formation is at the base of the upper plate. The rocks immediately below the thrust plane belong to the Gabbs, Sunrise, and Dunlap formations.

Movement was to the south or southeast and is believed to have been several miles. It is possible that the 
New York Canyon thrust is a segment of the East Ridge thrust in the Pilot Mountains.

Conglomerate along the plane of the New York Canyon thrust indicates movement over an erosion surface. In the area south of Sunrise Flat, a series of such conglomerates separated by thin slices of the dolomite unit of the Luning is evidence of successive advances of the thrust after quiet periods during which the frontal scarp was eroded (fig. 6).

The present attitude of the thrust plane is in part the result of Tertiary and Pleistocene tilting and faulting; but the plane has been warped prior to Tertiary faulting, and certain irregularities may be due to initial unevenness of the surface over which the thrust moved.

Folding prior to thrusting.-Rocks in the Gabbs Valley Range were moderately folded prior to thrusting, but the close overturned folds characteristic of the northeastern Garfield Hills and northwestern Pilot Mountains are lacking in this area.

The rocks of the lower plate of the New York Canyon thrust, except where contorted and overturned close to the thrust, show homoclinal southeasterly to easterly dips. South of Sumrise Flat a large fan of conglomerate and fanglomerate of the Dunlap formation is made up largely of pebbles of dolomite and limestone from the Luning and contains only a small proportion of limestone from the Sunrise on whose eroded surface it rests. The Dunlap in the New York Canyon area is conformable on the Sumrise, but also contains a large proportion of pebbles derived from the Luning. The presence of fanglomerate and conglomerate consisting largely of pebbles from the Luning suggests that a local trough, independent of those in the Garfield Hills and Pilot Mountains, may have developed during the early stages of folding, and that the early folds in the Luning to the north of this trough are now concealed beneath the New York Canyon thrust.

The folds in the rocks of the upper plate of the New York Canyon thrust are broad and are not overturned. In the northern part the folds trend northward; near Volcano Peak the synclines enclosing areas of the Sunrise formation trend northeastward; at the southeastern end of the range the folded limestone of the Luning trends westward parallel to the folds of the same limestone in the northeastern Pilot Mountains (sec. $\mathrm{H}-\mathrm{H}^{\prime}$, pl. 2).

Sunrise Flat thrust.-The Sunrise Flat thrust (pl. 2, sec. G-(G') crops out only in the lowland west of Sunrise Flat and is traceable for about 7,000 feet southeastward from the point where it is overlapped by the New York Canyon thrust. The thrust plane probably dips gently southwest, but this is not the original dip as the thrust was overridden by the New York Canyon thrust and was also subjected to Tertiary tilting.
The rocks above and below the thrust, greenstone and sandstone of the Dunlap on the lower plate and Sumrise overlain by Dunlap on the upper plate, dip southeast; and the position of the volcanic rocks of the Dunlap in the upper plate relative to those exposed below the thrust suggests a southward component of movement of nearly 2 miles.

New York Canyon thrust.-The outcrop of the New York Canyon thrust (pls. 2, 5; fig. 6) extends eastward in an irregular line for about a mile from the west front of the range. It is displaced by a normal fault but reappears on the east flank of the ridge west of Sunrise Flat, where the outcrop is continuous for more than 2 miles. Other segments crop out on the ridges south and southeast of Sunrise Flat.

The western part of the thrust (pl. 5), in the vicinity of New York Canyon, is irregular in plan. Near the mouth of New York Canyon, aplite is intruded along the thrust plane, but the position of the thrust is indicated by small masses of the Gabbs formation within the aplite close to the Sumrise of the lower plate. This segment of the thrust is broken by several normal faults. Along those west of Volcano Peak the downthrow is to the west so that rocks of the upper plate form the front of the range as far south as the intrusive aplite at the mouth of New York Canyon. On the two faults east of Volcano Peak, the downthrow is to the east, and the eastern (pl.5) displaces Tertiary lava.

A small canyon has been cut through the thrust plate between the faults east and west of Volcano Peak thereby forming a fenster bounded by normal faults on the east and west and by segments of the thrust on the north and south. On the north side of this fenster and just south of the crest of the peak, the limestone unit of the Luning overrides the Gabbs and Sunrise formations, which are much crumpled, in part overturned to the south and broken by minor thrusts. West of the peak both plates consist of highly sheared Luning. It is inferred that the trace of the thrust rums northwest, but because of widespread shearing and dolomitization of the limestone near the thrust plate its position could not be determined.

The small wedge of sheared conglomerate of the Dunlap along the thrust plane on the southern side of the fenster was probably deposited during thrusting.

Although major movement on the steep faults east and west of Volcano Peak appears to have been dominantly vertical, certain features suggest that the two major faults may have originated as tear faults during the earlier diastrophism.

South of Volcano Peak are three small overlapping thrusts (pl. 5, sec. $B-B^{\prime}$ ) in the Gabbs and Sunrise formations on which movement has been to the north, opposite to that of the major thrust. Each of these thrust planes dips gently to the south on its northern 


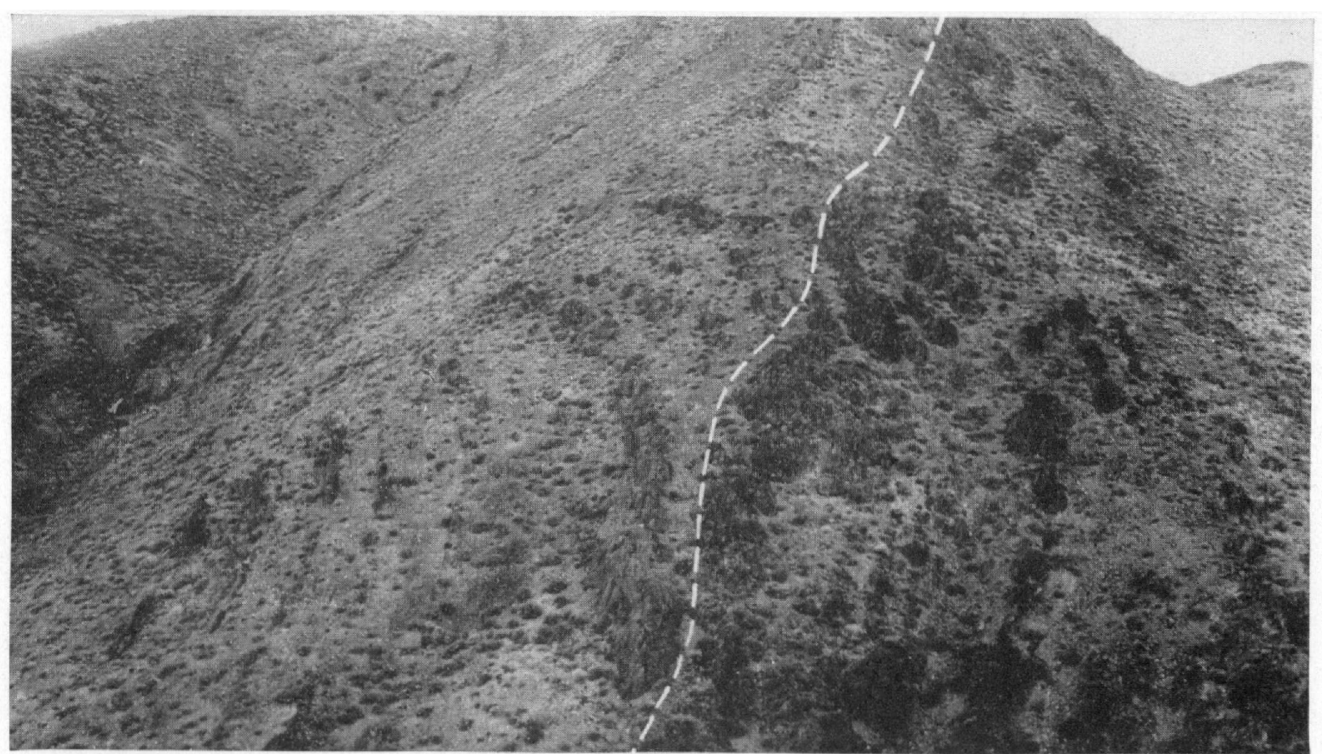

A, LIMFSTONE CONGLOMERATE OF DU NLAI FORMATION (RIGIT') UNCONGORMAILE ON IIMESTONE OF LUNING FORMATION.

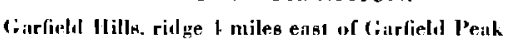

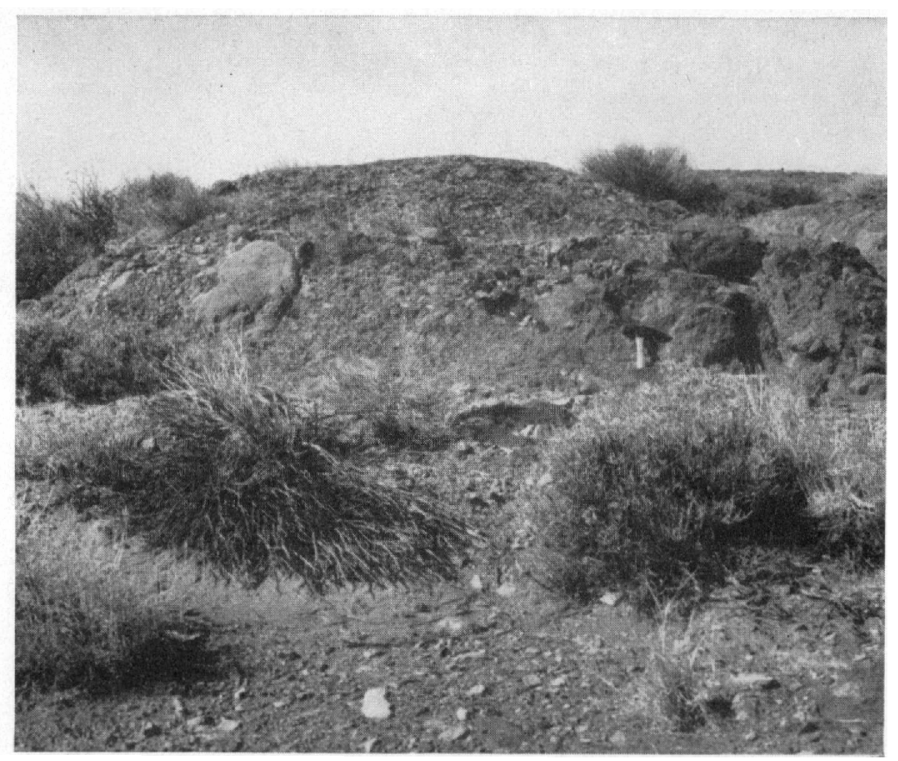

H, COARSE FANGLOMERATE OF LIMESTONE BOLLDERS IN DUNLAP FORMATION, OVERLYING LIMESTONE MEMBER OF LENING FOR.

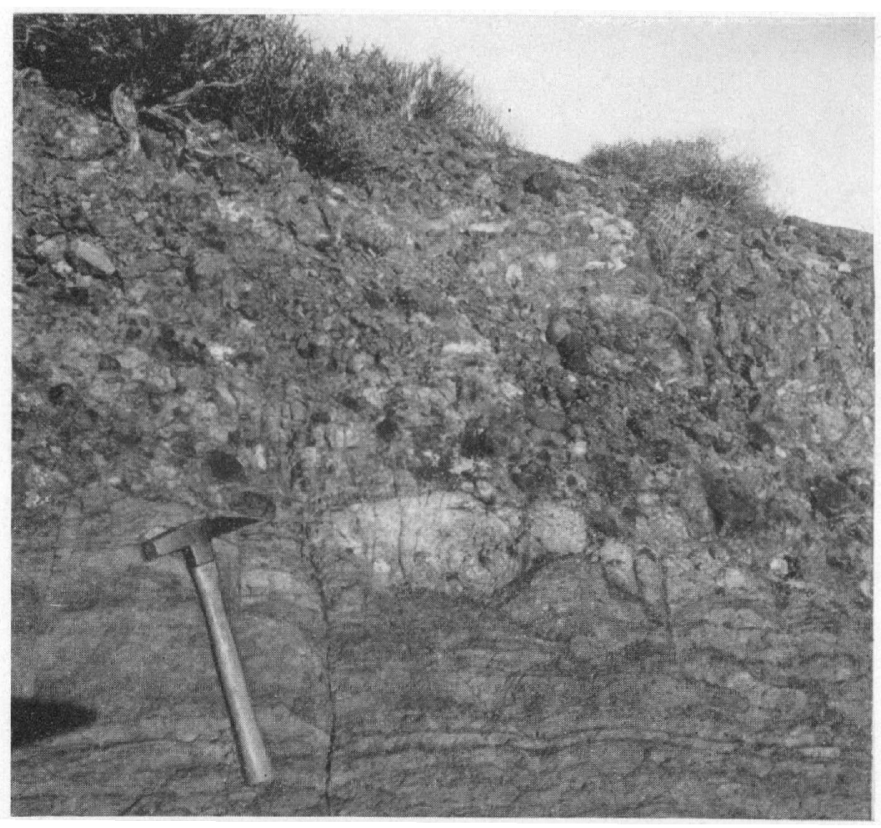

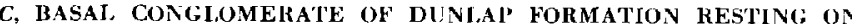
SLATE MEMBER OF LUNINC; FORMATION.

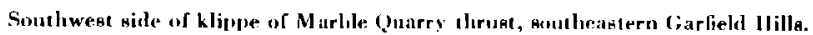

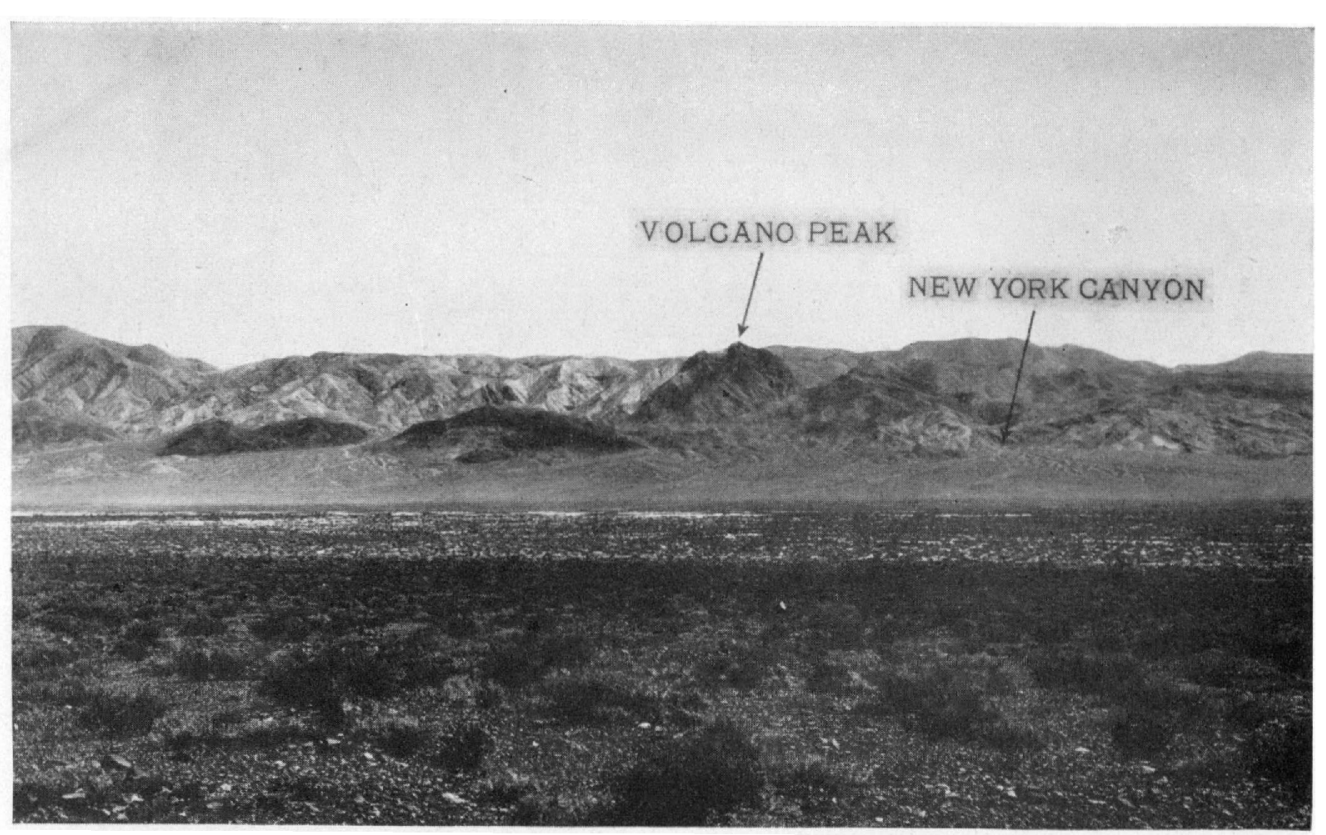

D, WEST FHON'T OF GABBS VALLEY RANGE.

Shows Volcano Peak and mouth of New York Canyon. Plotograph liy Flion Blackwelder. 

outcrop and sharply to the northwest or west in its eastern portion. 'The total northward movement does not exceed 1,000 feet. Aplite has been intruded along one of the steeply dipping planes, so the movement must have been earlier than the intrusion. Probably this "counter thrusting" was caused by impeding the southward movement of this part of the main thrust plate, forcing the thin-bedded shales and slaty limestones of the Gabbs and Sunrise, which here directly overlie the thrust, to slide northward over the more massive Luning. These "counter thrusts" are not found outside the area bounded by the steep faults, nor is the sharp upwarp of the thrust south of Volcano Peak repeated to the east and west. Therefore. the blocks on the east and west may have moved southward relatively freely, while impeded movement of the Volcano Peak block caused the warping of the major thrust plane and the formation of the small northward-moving "counter thrusts." The small faults east of the eastern fault, may have originated as tension fractures in the more freely moving block adjoining the eastern fault.

The eastern segment of the New York Canyon thrust crops out in the hills which border Sumrise Flat on the west and south (pl. 2). Along the eastern flank of the ridge west of Sunrise Flat, the Luning is thrust over the Sunrise and Dunlap formations.

At the southern end of Sunrise Flat (fig. 6) there is a zone as much as 300 feet thick in which from two to four thrust planes can be distinguished. On each of these, occasional lenses of conglomerate, consisting of partly rounded dolomite pebbles derived from the Luning of the upper plate, are closely pressed together but not sheared (pl. 6A). Bedding is discernible in a few places and is roughly parallel to the thrust plane. In the lower slices the dolomite of the Luning is overlain unconformably by sandstone and conglomerate of the Dunlap formation.

The thrust zone reappears southeast of Sunrise Flat, east of the normal fault that bounds the high eastern ridge. Orer most of the distance of outcrop there are two distinct thrust planes. The upper ends against a steep fault, probably a tear fault, in the canyon near the southeastern corner of the flat; the lower, which dips rather steeply eastward, can be traced for about a mile north where it is lost under the wash of Sunrise Flat. The slice between the lower thrust and the tear fault is as much as 300 feet thick and includes Luning folded into a steep northward-trending anticline overlain by Dunlap, which consists of dolomite-pebble conglomerate and red sandstone dipping gently enstward. The maximum unconformity between Dunlap and Luning in this locality reaches $55^{\circ}$.

The thick dolomite and limest one of the Luning formation on the ridge to the east was not explored in detail but no thrust appears to cut the Luning on the high hill to the east. The small area of Dunlap farthest to the north, on the east edge of Sumrise Flat, appears to be downfaulted against the Luning formation along a normal fault, not overthrust by the Luning as is the Dunlap farther south.

The southernmost outcrop of the thrust, in the isolated area of Mesozoic rocks 2 miles south of Sunrise Flat, appears to border a small fenster. The folded limestone of the Luning has overridden the sandstone of the Dunlap without the formation of an intervening "thr'ust conglomerate."

The thin thrust slices and the "thrust conglomerate" of the Sumrise Flat area (fig. 6) are believed to be the result of local and temporary balance between erosion and intermittent movement of a surface thrust. It is supposed that a considerable thickness of the limestone and dolomite of the Luning formed the upper plate of the thrust, which moved over a surface cut on the volcanic rocks of the Dunlap and locally overrode gravel derived from the advancing thrust plate. Cessation of forward movement would permit the frontal scarp of the upper plate to be worn back, leaving a pediment containing small klippen of dolomite and patches of dolomitic gravel, or a thin sheet of the Luning of the upper plate. Renewal of movement would culuse a new break to form at the junction between scarp and pediment and the overthrust block would again move forward over the pediment. Repetition of this process, with a delicate balance between the length of periods of retreat of the scarp, the depth of erosion, and the amount and time of forward movement, would result in the successive thin thrust slices separated by dolomitic gravel that are found in the area south of Sunrise Flat. Where the speed and timing of the various processes were not in such accidental adjustment, the relics of earlier movement would be stripped off prior to the next pulse of forward movement if the interval were long; or, if the interval were shorter, no pediment would be formed, the successive forward movements would continue along the erosion surface, and only here and there a single bed of gravel would be derived from the upper plate.

The direction of relative movement of the upper plate of the New York Canyon thrust was south or southeast. South of Volcano Peak, the direction of longitudinal grooves in the thrust plane and of overturned folds, and subordinate thrusts in the underlying Gabbs and Sunrise formations indicates southward movement. In the Sunrise Flat area a nearly southeast direction is suggested. Movement is believed to have amounted to several miles, but there is little on which to base a definite estimate. The lower plate formations bordering the southern part of Sunrise Flat appear to form part of a fenster about 4 miles in length from north to south, whose northern and southern boundaries are concealed. 

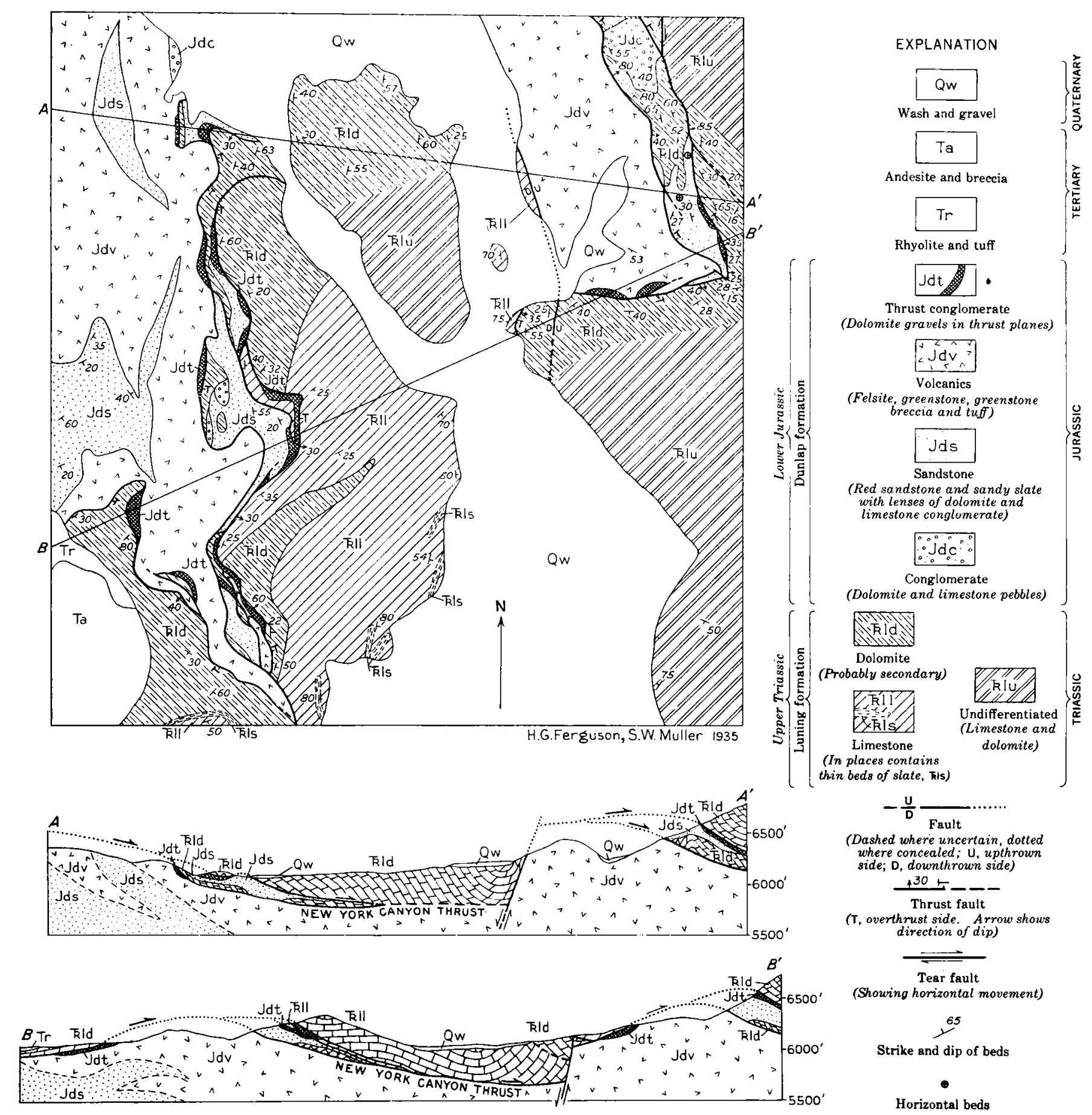

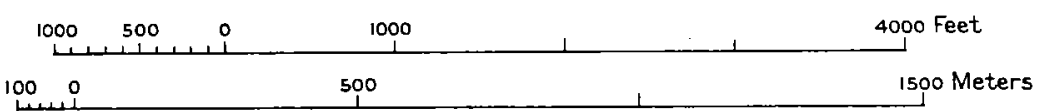

Frgurw 6.-Geologic map and sections of area south of Sunrise Flat, Gabbs Valley Range, showing nelation of "thrust conglomerates" to New York Canyon thrust.

The difference in character of the Luning formation, dominantly massive dolomite in the upper plate and limestone in the lower, suggests movement of greater magnitude.

The New York Canyon thrust and the East Ridge thrust of the Pilot Mountains (p. 36) may be parts of the same major thrust. The Luning in the upper plate of the New York Canyon thrust crops out nearly continuously from the southeast corner of Sunrise Flat to the extreme southeast end of the range near Battle's Well. The limestone unit of the Luning formation north of Battle's Well is the same as the upper limestone unit above the East Ridge thrust in the Pilot Mountains. The folds follow the same direction as 
they do in the northern part of the Pilot Mountains. The East Ridge thrust lacks the "thrust conglomerate" which is so prominent along the plane of the New York Canyon thrust, but if this conglomerate depends upon the coincidence of accidents of topography and intermittent movement on the thrust, it could not be expected to occur along all parts of the thrust plane.

Later folding and tilting.-The thrust plane appears to have been somewhat deformed after movement along it ceased, and prior to the Tertiary faulting and tilting. The change in dip, from northward on Volcano Peak to southward at the south end of the fenster (pl. 5), was possibly accentuated by tilting associated with Tertiary movement but may be largely due to the impeding of forward movement in this sector. Or the change in dip may be coincident with the emergence of the thrust plane at the surface, as suggested by the presence of the thrust conglomerate at the southern border of the feuster (p. 26).

In the region south of Sumrise Flat there has been warping distinct from Tertiary tilting. South of the flat and just east of the overlapping Tertiary lava, the sharp southward reëntrant of the outcrop of the thrust marks the position of a gentle fold. East of the southern end of Sunrise Flat, the outcrops of the eastern segment of the thrust, here two parallel thrust planes a few feet apart, bend at nearly right angles, and the planes are irregularly crumpled and fluted. Above the upper plane the dolomite of the Luning formation, though crumpled close to the thrust, seems in general to be folded with the thrust. It is possible, however, that Tertiary tilting may have played some part, accentuating the eastward dip of the lower plane by tilt of the uplifted fault block.

The southward decrease in altitude of the outcrop of the thrust, in the western part of the range, however, corresponds closely with the gentle south to southwest dips of the overlying Tertiary lava.

In the central part of the range, a fault which continues the direction of the fault scarp bordering the range to the south, crosses the range diagonally (pl. 1). Within the range, however, Tertiary rhyolite lies northeast of the granodiorite along the southeastern part of the fault. Although the net stratigraphic downthrow therefore is to the northeast, the fault line is marked by a steep southwestward-facing scarp of pumiceous rhyolite. As the rhyolite is more readily eroded than the granodiorite, it is improbable that the scarp is a reversed scarp due to erosion.

It seems reasonable to suppose that the relative positions of rhyolite and granodiorite are a result of dominantly horizontal movement on the fault, the northeast block moving to the southeast. If this possibility were susceptible of definite proof, it would furnish evidence for late Tertiary movement on the inferred Soda Spring Valley flaw.
The present relations may, however, also be explained by inferring two periods of movement along the faultan earlier movement that resulted in downthrow on the northeast and a later one in downthrow on the southwest to a smaller extent-sufficient to give the present topographic expression and to continue the fault scarp of the Gabbs Valley Range. The position of the andesite that flanks the eastern slope of the range, east of the fault, accords with this explanation; but, as the surface on which the andesite was erupted is highly irregular, it is not conclusive.

\section{PILOT MOUNTAINS}

The Pilot Mountains contain a large area of essentially unmetamorphosed Mesozoic rocks. The steep scarp on the western front and the deep dissection in the central part of the range offer exceptional opportunities for study of the complex folding and thrusting near the margin of the Luning embayment.

The east and west fronts of the range are steep fault scarps, that on the west is higher and probably the more recent. The central part of the range is cut by Dunlap and Cinnabar Canyons and their tributaries. These drain northwestward to the low gap between the Pilot Mountains and Gabbs Valley Range. South of the heads of these canyons a high ridge culminates in Pilot Peak. The range is horseshoe-shaped, open to the north; and the arms will be referred to as the East and West Ridges and the base, as the South Ridge.

The geology of that part of the range north of the Excelsior contact, including roughly the East and West Ridges and parts of the South Ridge, was mapped in some detail; but, except for two traverses south from Pilot Peak, the southern part of the range is known only from reconnaissance.

\section{ROCKS EXPOSED}

Excelsior formation.-The Excelsior formation occupies the entire southern part of the range and occurs in small thrust wedges in the complex northwestern part. The main mass of Excelsior consists essentially of dark massive chert, fine-grained silicified tuff interbedded with coarser tuff, and a little dark tuffaceous sandstone (pl. $6 B$ ). The thickness is uncertain, but 10,000 feet is probably a minimum estimate. Greenstone, greenstone breccia, and felsite are present in some places and for the most part, underlie the chert and tuff. Diabase dikes and sills and a few basic intrusive rocks cut the Excelsior but do not cut the Luning and higher formations. The thrust wedge of Excelsior north of Mac Canyon is composed of greenstone, greenstone breccia, and a little bedded tuff but contains no chert.

Luning formation.-The Luning formation occupies the northern part of the range and includes two limestone units, each about 2,500 feet thick, separated by a 
slate and conglomerate unit having a maximum thickness of about 3,000 feet. The upper massive dolomite elsewhere present at the top of the Luning is not present in this range, and such dolomite as is present in the upper limestone is probably the result of secondary alteration. A few slate belts occur in the upper limestone. The character of the rocks in the different thrust plates varies slightly.

Sunrise formation.-The Gabbs formation, which normally overlies the Luming, does not crop out in the Pilot Mountains, and the only exposure of the younger Sunrise formation is a small area in the lower part of Mac Canyon below the folded Mac thrust. The rocks are thin-bedded limestone underlain by dark slate. The total thickness exposed may be 600 to 800 feet.

Dunlap formation.-The lower part of the Dunlap) formation consists of red cross-bedded sandstone and a varying amount of chert conglomerate which is most abundant near the unconformable contact with the Excelsior formation and is also present in small lenses throughout the sandstone. In contrast to the thick section of volcanic rocks in the Dunlap of the Gabbs Valley Range, only a little greenstone and greenstone breccia is found in the upper part of the sandstone in the Pilot Mountains. Beds and lenses of dolomite and limestone at and near the top of the sandstone, though not continuous, probably mark approximately a single horizon. The upper part of the Dunlap consists principally of coarse conglomerate largely composed of limestone and dolomite pebbles derived from the upper unit of the Luning formation. There is similar conglomerate along the plane of the overturned Mac thrust, which carries the upper unit of the Luning above the Sumrise. The thickness is highly variable; as much as 5,000 feet may be present in the vicinity of Dunlap Canyon, with the upper part concealed beneath the overthrust Luning.

Intrusive rocks. - Granitic rocks occupy a relatively small area in the Pilot Mountains. Several masses, chiefly of granodiorite, cut the Excelsior on the west flank of the range and the Luning on the east flank. Dikes of aplite in places follow the thrust planes, and small masses of aplite cut the Excelsior and Dunlap on the west front of the range and near the head of Dunlap Canyon. A dike of peridotite, less than 100 feet wide and cutting both aplite and granodiorite, was traced southward from the head of Mac Canyon 21/4 miles across the granodiorite south of Spearmint Canyon.

\section{STRUCTURE}

The structure in the Pilot Mountains is the most complex in the area. The writers are by no means confident that they have everywhere reached the correct explanation. Each time during several field seasons that the area was revisited, new complications were dis- covered, and restudy of previously mapped areas brought new interpretations.

The Excelsior formation of the South Ridge was strongly folded and overturned to the north prior to the warping and sinking that permitted the deposition of the Luning, Gabbs, and Sunrise formations. The lower part of the Dunlap formation was deposited in a basin, which overlapped the contact of Luning and Excelsior. The beginning of the Jurassic folding was marked by the formation of a local trough within this basin. This trough received the conglomerate and fanglomerate from the rising folds and incipient thrusts to the north. Apparently local deepening of this trough accompanied the early folding and thrusting in the area now included in the northwestern part of the range. The earlier folds and thrusts, including the Mac and Spearmint thrust planes (pls. 3, 7, 8), were themselves strongly folded by pressure from the north that developed a large recumbent fold and additional thrusts in the hills north of Mac Canyon. This folding and thrusting appears to have been local and determined by the position of the trough that received the detritus from the Luning formation on the north while the early folding and thrusting were in progress. The deformation may have been complicated by irregularities in the original surface of deposition, as suggested by the mass of Excelsior north of Mac Canyon.

It is believed that the northwestern part of the range, compacted by early close folding, was uplifted and acted as a partial obstruction to later more widespread folds. This obstruction forced the folds to deflect around it thus changing their trends and resulting in local overturn to the north near the mouth of Dunlap Canyon. The Dunlap Canyon and South Fork thrusts were later than a part of this folding, but the Dunlap Canyon thrust plane is folded along the same general trends as the folds in its upper plate. The amount of movement on these thrusts is probably not large, as the rocks involved do not show any differences in facies. The Cinnabar Canyon thrust appears to be later than the early folding and thrusting; and, like the Garfield Flat thrust in the Garfield Hills, it carried rocks previously thrust and folded, southward against the marginal Excelsior and Dunlap.

The East Ridge thrust, of later date and greater magnitude, brought gently and regularly folded Luning above the Cinnabar Canyon thrust block. The uplifted area of more complex folding on the northwest, seems to have forced the thrust to move along an irregular plane locally steeply inclined. The more westerly segments which moved southward at higher altitudes are now removed by erosion.

Granitic intrusion was confined to the east and west flanks of the range and had no apparent effect on the structure. 
Faults of Tertiary and later age are present on the east and west fronts and in part bound the older rocks on the north. To some extent movement along faults initiated during the Jurassic folding may have been renewed in the Tertiary.

The structural history of the range will be described in the following approximately chronological order: (1) The pre-Jurassic folding of the Excelsior of the southern part of the range; (2) the deposition of the Dunlap sediments; (3) the early folding and thrusting in the northwestern part of the range; and (4) later thrusting.

\section{PRE-JURASSIC FOIDING}

Both the Luning and Dunlap formations overlie the Excelsior with a high degree of angular unconformity. The Luning on the west front of the range, south of Spearmint Canyon (pls. $\tau, 8$ ), dips from $50^{\circ}-70^{\circ} \mathrm{N}$., whereas the dip of the underlying chert of the Excelsior formation varies from $80^{\circ}-65^{\circ} \mathrm{S}$. On the northern flank of the South Ridge the prevailing dip of the Dunlap formation near the Excelsior contact is to the northeast and the underlying Excelsior dips irregularly but in the vicinity of Pilot Peak generally to the south; therefore if the original condition that existed during the Dunlap sedimentation were restored, the Excelsior near the contact would dip more steeply.

Traverses from Pilot Peak southward revealed that the folds in the Excelsior formation generally trend east. The principal syncline is overturned to the north (pl. 2, sec. $H-H^{\prime}$ ), in contrast to the southward thrusts and associated folds in the Luning formation.

\section{DEPOSITION OF THE DUNLAP SEDIMENTS}

The sediments of the Dunlap formation record the first stages of the Jurassic diastrophism. The widespread basal conglomerate composed of chert pebbles indicates that the lower part of the Dunlap was derived from the Excelsior rocks, which lay to the south. The basal conglomerate ranges in thickness from a few feet to more than 200 feet, and lenses of chert conglomerate occur throughout the lower part of the formation.

Near the contact the attitude of the Dunlap parallels the trend of the contact, but exceptional clifflike exposures in which angular talus at the base of the Dumlap border steep north trending segments of the contact suggest that the basin in which the Dunlap was deposited was deepened in places by faulting transverse to the general westerly trend.

The thin beds of marine limestone and dolomite near the top of the sandstone appear to mark roughly a single horizon. If so, the amount of the depression must have varied greatly, for the underlying sandstone attains a thickness of 2,500 feet or more on the West Ridge (pl. 7 ), whereas, 3 miles east at the hend of Cin- nabar Canyon, only 700 feet of sandstone underlies 500 feet of interbedded limestone and sandstone.

The beginning of folding to the north is reflected in the change in character of the Dunlap above the limestone horizon. The material that forms the conglomerates and fanglomerates of the upper part of the Dunlap is largely derived from the Luning. The rising folds of the upper limestone of the Luning formation, from which the overlying rocks had been eroded, and the thrusts toward the trough yielded the coarse material which makes up the upper part of the Dunlap. Conditions were presumably similar to those in the southeastern Garfield Hills, but in the Pilot Mountains the depositional contact of Luning and Dunlap is concealed by later thrusts.

Folding was less intense in the area underlain by Dunlap than it was to the north. The upper conglomerate of the Dunlap outlines two northwesterly synclines, with superposed minor folds. Overturned folds are confined to the vicinity of the overriding thrust plates, and in general the dips become more gentle to the south, near the Excelsior contact.

\section{EARLY JURASSIC FOLDING AND THRUSTING}

Outline of structural development.-The northern part of the Pilot Mountains (pls. 3, 7,8) consists of a succession of thrust plates, each containing folded rocks, chiefly of the Luning formation. The structure of inclividual plates becomes increasingly complex downward.

This early folding and thrusting was the result of pressure from the north and is correlated with the local development of the trough in which the upper conglomeratic part of the Dunlap formation was deposited. The great thickness of conglomerate derived from the north indicates that sedimentation in this trough went on at an accelerated rate during the early stages of folding and during the early thrusting on the Mac and Spearmint thrusts. Initial folding of the thrusts, which moved over erosion surfaces, must have taken place under a very shallow cover. Erosion during folding and thrusting of the massive upper limestone and dolomite units of the Luning formation, yielded the conglomerates of the upper part of the Dunlap in the trough to the south. The shale and shaly limestone of the overlying Gabbs and Sumrise formations did not yield recognizable fragments.

The Mac thrust carried the gently folded upper limestone and slate members of the Luning above an erosion surface cut on the Sunrise formation, itself folded and broken by a minor thrust. The warping of the plane of the Mac thrust, as the Dunlap trough continued sinking, and the accumulations of debris in front of the thrust erentually prevented further movement. A new break formed further to the north along which the 
Spearmint thrust carried the lower limestone of the Luning and slices of the overlying Excelsior basement over the new erosion surface.

Probably the recumbent fold in the upper limestone of the Luning and its accompanying thrusts were developed when the folding, which buckled the Spearmint thrust (pls. 7, 8), had compacted the area between the Mac and Spearmint thrusts, forcing the development of new folds just to the north. The actual involution that caused the peculiar reversal of dips was presumably later, possibly contemporaneous with the compression that resulted in the formation of the Northwest thrust.

The mass of greenstone of the Excelsior formation north of Mac Canyon may have been a contributing factor in the localization of this complex structure. If, as is likely, the Excelsior basement was an irregular surface at the time of Luning deposition, protuberances of Excelsior would have been sheared off by the early thrusts and these less compressible masses would locally complicate the structure. The resistance to folding offered by such a mass as that north of Mac Canyon may have caused the formation of the Northwest thrust.

The total shortening of the rocks north of Spearmint Canyon cannot be determined but must amount to several times the present width of the area $(\mathrm{pl} .3)$. The extreme compression was confined, however, to a relatively narrow belt. Tertiary and Pleistocene lava and gravel conceal the older rocks north of the area mapped; and the nearest outcrop of Mesozoic rocks to the north is 5 miles away, in the New York Canyon area of the Gabbs Valley Range where the upper plate of the New York Canyon thrust, which is probably equivalent to the East Ridge thrust of the Pilot Mountains, covers most of the exposed area. The rocks below the New York Canyon thrust are not greatly folded, however, and the Dunlap rests on the Sunrise with only moderate erosional unconformity. It is inferred, therefore, that intense compression was largely localized and that the roots of the folds and thrusts are concealed under the lava and gravel in the area between the northwestern part of the Pilot Mountains and the southern part of the Gabbs Valley Range. Movement on individual thrusts was probably small, possibly a few miles at most.

Mac thrust. - The Mac thrust, which brings the Luning above the Sunrise near the mouth of Mac Canyon and above the Dunlap in the small fensters a mile to the east, is folded into a closely compressed and overturned anticline. On the north wall of the canyon the upright part of the thrust plane dips north; but about half a mile above the mouth the plane bends sharply (pls. $6 C, 9 A$ ), and on the south wall of the canyon the thrust plane is nearly vertical close to the bend but is overturned as much as $40^{\circ} \mathrm{N}$. near the canyon mouth.

There is conglomerate derived from the now overturned Luning between the Luning and Sunrise forma- tions indicating that the overturned thrust plane was originally an erosion surface. This "thrust conglomerate" (pl. $9 B$ ) consists of dolomite pebbles similar to those in the conglomerate in the upper part of the main mass of Dunlap a mile to the southeast, and lacks pebbles derived from the Sunrise formation. The conglomerate is sheared but is not faulted at the contact with the Luning, and in only a few places is there shearing at the contact with the underlying Sunrise formation. The pebbles, though closely pressed together, are not stretched. For the most part bedding planes are lacking, but in places lenses of sandstone indicate a dip essentially parallel to the thrust plane, contrasting with the complexly folded Luning, which has overridden the conglomerate but now lies beneath it.

This gravel must have lubricated the movement of the upper plate, for where the conglomerate is lacking, the dolomite close to the thrust is minutely fractured $(\mathrm{pl} .9 \mathrm{C})$. Where there is conglomerate along the thrust, the bedding of the dolomite is well preserved though occasional dikelike apophyses of sand and small dolomite fragments have been injected several feet into tractures in the dolomite (pl. $9 B$ ). Some movement may have occurred along the irregular shear planes within the conglomerate, but for the most part, the rolling and dragging of unconsolidated gravel have left no evidence of movement. There is also local shearing hetween the conglomerate and the Sunrise formation of the lower plate, but no continuous fault contact. No evidence is found here, as in the Gabbs Valley Range, of periods of forward movement alternating with periods of erosion. The present distribution of the conglomerate must have been determined by accidents of the prethrust topography and of the varying speed of movement of the upper plate. The "thrust conglomerate" crops out continuously from the thrust contact of Luning and Sunrise on the south wall of the Canyon, southward and up the ridge nearly to the crest. Its presence south of and above the outcrop of the Sunrise formation of the lower plate thus indicates the degree of overturn of the fold in the Mac thrust as well as the position of the crest of this overturned fold. "Thrust conglomerate" is also exposed in two small fensters in the Mac thrust 4,000 to 5,000 feet from the mouth of Mac Canyon.

The Sunrise formation below the thrust is folded, approximately parallel with the thrust, into a steep anticline that is broken by a thrust on the northern limb.

Stratigraphically the upper limestone unit of the Luning in the upper plate and the Sunrise formation in the lower plate are only a few hundred feet apart, but the total movement on the thrust presumably exceeds the distance represented by the folded thrust plate exposed in Mac Canyon and the length from north 
to south of the portion of the upper plate exposed between Mac and Spearmint Canyons.

The upper limestone unit of the Luning, which forms the upper plate of the Mac thrust, is overridden by later thrusts, so that on the north side of Mac Canyon a small sliver only is exposed (pl. $9 C$ ). South of Mac Canyon, complexly folded Luning underlies most of the hill between the mouths of Mac and Spearmint Canyons (pl. $6 D)$. For the most part the Luning consists of the upper limestone unit containing much dolomite, probably largely secondary, and several bands of slate. The slate unit of the Luning formation, which is distinct from the small bands of slate within the upper limestone unit, crops out in three tightly folded bands between the Mac and Spearmint thrusts. These outcrops mark the crests of anticlines modified by subordinate thrusts. Elsewhere, lack of identifiable key beds prevented the deciphering of the structure of the highly folded limestone, and scattered observations of attitude cannot be correlated satisfactorily.

Spearmint thrust.-The Spearmint thrust carries the greenstone of the Excelsior formation and the lower limestone unit of the Luning above the upper limestone in the upper plate of the Mac thrust; the plane is also folded, though less closely than that of the Mac thrust and not symmetrically with it (pl. 8). On the low ridge between the forks of Mac Canyon the thrust plane is overlapped by the Dunlap Canyon thrust, but near the head of Mac Canyon the plane bends but much less sharply than the Mac thrust. South of this bend across the ridge between Mac and Spearmint canyons the thrust plane holds a fairly straight course, the easterly dip steepening to vertical south of the crest. Near Spearmint Canyon the strike changes sharply to the west, and the steeply overturned plane dips to the north (pl. $9 D$ ); and on the cliff facing Soda Spring Valley the upper plate contains greenstone of the Excelsior overlain by the lower limestone unit of the Luning.

On the divide between Mac and Spearmint Canyons there are at least two nearly parallel thrust planes so that the lowest unit in the upper plate is a complexly sheared narrow belt of the lower limestone overthrust by the greenstone. Where the Spearmint thrust crosses the low ridge between the forks of Mac Canyon it overrides minutely contorted sandstone of the Dunlap formation containing a little conglomerate ( $\mathrm{pl} .10 \mathrm{~A}$ ), which is unconformable on the Luning of the lower plate. The intricate contortion suggests that the sandstone was unconsolidated at the time of movement along the thrust.

In a north-south direction the maximum extent of the exposed portion of the lower plate of the Spearmint thrust exceeds 6,000 feet, and movement must have been much greater than this because greenstone of the Excelsior and the lower limestone of the Luning formation are thrust over the upper unit of the Luning.
The inferred development of the Mac and Spearmint thrusts is shown diagrammatically in plate 3 . It is believed that, as the upper plate of the Mac thrust moved southward into the trough in which the Dunlap sediments were being deposited, continued depression of the trough, accumulation of waste in front of the thrust plate, and uplift at its northern border combined to warp the plane so that further movement became impossible. Compression was contemporaneous with the depression of the trough, and a new break, the Spearmint thrust, was formed, extending from the north limb of the folded Mac thrust to the surface. Starting on this fracture, the Spearmint thrust moved southward over the erosion surface cut on the upper plate of the Mac thrust until it too was folded and new thrusts formed to the north. Thus, if the Dunlap trough were being constantly deepened and received the sediments from the thrust plates as they moved south ward, these thrusts probably "bogged down" within the Dunlap trough and never reached the "buttress" of chert of the Excelsior formation. Consequently, the pressure was relieved first by folding and later by the formation of higher thrusts.

The Mac and Spearmint thrusts crop out close together on the north wall of Mac Canyon, so that west of the sharp bend in the Mac thrust, there is only a thin sliver of the much fractured upper unit of the Luning formation (pl. $9 D$ ). This pinches out to the west near the mouth of the Canyon where the Spearmint thrust merges with the Mac thrust and brings greenstone of the Excelsior in contact with the Sunrise formation of the lower plate of the Mac thrust.

Above the Spearmint thrust on the north wall of the Mac Canyon the greenstone of the Excelsior is faulted against the lower limestone of the Luning. The fault dips steeply to the east and must be a tear fault as it does not cut the underlying Spearmint thrust (pls. 7,8). On the west and north, the Excelsior is overlain by the lower limestone of the Luning on a normal unconformable contact.

Northwest thrust.-The area north of Mac Canyon, including the range front on the west and the 6,500-foot hill north of the head of the canyon on the east, consists of two thrust slices separated by the Northwest thrust. The rocks in both plates are folded, those of the upper plate to an unusual extent, but the thrust plane does not show the extreme folding which characterizes the underlying Mac and Spearmint thrusts.

Except for the greenstone of the Excelsior and the small sliver of slate of the Luning above the Spearmint thrust, the lower limestone unit of the Luning forms the exposed portion of the plate below the Northwest thrust. The thin-bedded limestone east of the tear fault is highly crumpled and fractured, and its structure is not determinable. 
The Northwest thrust in general strikes west, and at the outcrop dips gently north. Along the western part of its outerop the slate unit of the Luning formation is thrust over the lower limestone. To the east limestone is on both plates so that the plane camnot be traced eastward with certainty. It is probably overlapped by the Dunlap Canyon thrust (pls. 7,8).

'The thrust plane is broken into three segments by two faults, which strike north-northeast and dip steeply west. The plane of the eastern fault is well exposed and shows grooves that pitch $65^{\circ} \mathrm{SW}$.; but the relation of the displacement of the overturned upper limestone in the upper plate to the apparent offset of the gently dipping thrust plane is such that it appears very doubtful if the major movement, particularly along the westem fault, could have been in this direction. It seems likely that these breaks originated as tear faults in the upper plate of the Northwest thrust, and that the grooves resulted from more recent movement. A welldeveloped fault scarp fronts the range southward from Mac Canyon, and small scarps were observed also in the gravel bordering the range front. North of the area shown in plate 7 , the scarp in the tilted Pleistocene gravels bordering the range is a prominent feature of the topography; however, no recent faulting along the range front between Mac Canyon and the northern limit of the mapped area is indicated. Therefore, Tertiary and later movement along this part of the range may well have followed those existing faults that were favorably alined.

The upper plate of the Northwest thrust consists of highly folded upper limestone and slate of the Luning formation. The outcrops of the upper limestone mark the crest of an involuted fold, that is, the trough of a recumbent syncline, which has been so rotated by later folling that it now appears as an anticline in part upright and in part overturned to the south. The upper limestone on the 6,500 -foot hill dips beneath the slate except for a short distance along the sonthern border where the dip is about vertical. In places the beds are overturned to as much as $10^{\circ}$ from horizontal. In the two segments to the west, the upper limestone dips beneath the slate on the north but is thrust over the slate on the south. These thrusts are probably small, as there is no appreciable break in the normal stratigraphic sequence. The degree of overturn decreases enstward and the gentle overturned dips steepen eastward from the 6.500-foot hill and approach the vertical at the contact of the slate and lower limestone. This steepening of dip in part may be due to later upwarp superposed on the earlier folds.

The lower limestone on the ridge north of the upper part of Mac Canyon, just above the Northwest thrust, is overturned along its western and part of its northern border and the slate member dips beneath the limestone, possibly marking the position of the complementary involuted anticline.

The apparent variation in thickness of the slate unit as measured in different directions from the outcrop of the upper limestone on the 6.500 -foot hill must be due to flow, disharmonic folding, and minor thrusting within the slate. On the top of the 6,500-foot hill, individual conglomerate beds in the slate unit can be traced around and parallel to the contact of the upper limestone. On the south sicle of the hill, where the attitude of the lower contact changes from overturned to normal and again to overturned, the conglomerate beds are irregularly spaced within the slate. Two beds close together in one place, if traced a short distance, may be several hundred feet apart. Similarly the individual beds are discontinnous and appear to have been broken apart when the more plastic slate was deformed.

No folding of the plane of the Northwest thrust is evident from the trace of its outcrop; but the Dunlap Canyon thrust, which apparently overlaps the Northwest thrust, is moderately folded. The plane of the Northwest and Spearmint thrusts, therefore, may also be folded inasmuch as folding with an easterly trend would not be evident from the outcrop.

The extent of the Northwest thrust beneath the Dunlap Canyon thrust and the magnitude of movement are unknown. The intense folding is probably concentrated, however, in a rather narrow belt; and, therefore, since the Northwest thrust carries highly folded rocks, its displacement is probably small.

Dunlap ('anyon thrust.-The name, Dunlap Canyon thrust, is applied to a group of closely spaced thrust planes that partly surround the area of close folding just described. The major thrust plane of this group overlaps the Northwest thrust and in turn is overlapped by the South Fork thrust. To the south it is cut off by the Cimnabar Canyon thrust.

Orer much of the area traversed by the Dunlap Canyon thrust, thin-bedded limestone of the lowest unit of the Luning on both plates is crumpled and fractured. Consequently, except where the more massive limestone near the top of this mit is present. the thrust planes are not easily traced, and they may be more numerous than shown on the map.

The thrust planes for the most part dip away from the area of intense foldling (pl. 8), therelyy suggesting that continued uplift warped the area deformed by early folding and thrusting. The isolated segments of what is assumed to be the same thrust plane dip to the north in the extreme northwest part of the area, and to the east along the outcrop east of the 6.500 -foot hill. To some extent the trends of the folds in the upper plate parallel the attitude of the thrust planes, but the dips are generally steeper. Uplift of the intensely folded area might account at least in part for 
the approximate parallelism of the folds in the upper plate of the Dunlap Canyon thrust with the folded thrust plane itself. 'The uplift may in part have preceded movement on the Dunlap Canyon thrust, and the resistance to the thrust offered by this local uplift may partly account for the change in trend of the folds above the Dunlap thrust and the local backfolding of the anticline in Dunlap Canyon (sec. $B-B^{\prime}$, pl. 7 ).

The outcrop of this thrust is traceable from the point where it is overlapped by the South Fork thrust, to Spearmint Canyon where it is cut off by the later Cinnabar Canyon thrust. Southward from the saddle east of the 6,500-foot hill, there is lower limestone on both plates; and the thrust zone is probably less simple than is shown on the map, for the slaty thin-bedded limestone is highly sheared and much crumpled, and the beds of more massive limestone that border the slate unit in the upper block are broken and discontinuous near the thrust.

Probably no large morement occurred along the Dunlap Canyon thrust. Rather, it seems to be the result of intense compression largely concentrated in the incompetent lower limestone unit of the Luning formation. The maximum distance from the northern to southern outcrops is about 2 miles, but the total movement may be less than this.

South Fork thrust.-The upper plate of the South Fork thrust (pls. 7, 8) is represented only by klippen of the lower limestone unit of the Luning. The smaller klippe east of South Fork rests on the slate unit of the Luning, the larger, extending northwestward from South Fork, carries the lower limestone above slate and lower limestone and overlaps the Dunlap Canyon thrust. The smaller klippe is in large part obscured by Tertiary rhyolite so that neither the attitude of the thrust plane nor the structure of the upper plate could be determined. In the larger klippe the thrust plane appears to dip gently inward from the margins.

On the larger klippe, the inverted position of the "cabbage head" corals in a distinctive bed of coralline limestone indicates that, at the eastern end, the structure is the orerturned syncline-like crest of a completely involuted anticline (sec. $B-B^{\prime}$, pl. 7 ). The coral-bearing beds normally occur near the top of the lower limestone. Except for a narrow zone of drag, the thrust does not appear to have disturbed the underlying structure.

No direct estimate of the amount of movement on the South Fork thrust is possible, but the involuted structure on the upper plate suggests that the movement may have been small and confined to the belt of highly folded rocks that border the Dunlap trough. The klippen can scarcely be outliers of the East Ridge thrust sheet, for the distinctive massive coral limestone beds in the lower limestone of the klippe are characteristic of all the lower thrust plates including that of the klippe, but not of the lower limestone above the East Ridge thrust.

\section{LATER THRUSTING}

The Cinnabar Canyon, West Ridge, and East Ridge thrusts are believed to be of later date than the intense folding associated with the thrusts just described, and to have ruptured the previously folded rocks. The Cinnabar Canyon thrust, like the Garfield thrust in the Garfield Hills, departs from the usual stratigraphic sequence of thrusts in that it carried the folded thrust blocks from the northwest part of the range southward over the gently folded Dunlap formation. Movement on the West Ridge thrust was to the north and may have been earlier than or contemporaneous with the Cinnabar Canyon thrust. The East Ridge thrust is probably of greater magnitude than any of the others as it overlaps the Cinnabar Canyon thrust and has carried the folded Luning formation southward across the Dunlap to the Excelsior contact, along alternating gently and steeply dipping planes. The East Ridge thrust may be the same as the New York Canyon thrust of the Gabbs Valley Range (p. 26).

Cinnabar Canyon thrust.-The outcrop of the Cinnabar Canyon thrust (pls. 3, 7) extends from Soda Spring Valley eastward to East Ridge where it is overlapped by the East Ridge thrust. Along the Cinnabar Canyon thrust, the Luning formation is thrust over the marginal Dunlap, which overlies the Excelsior.

The western part of the thrust crops out along Spearmint Canyon. For a mile upstream from the mouth of the canyon the average strike is about nurtheast. The dip near the mouth of the canyon is $70^{\circ} \mathrm{NW}$., changing to nearly vertical 3,000 feet from the canyon mouth and again to about $60^{\circ} \mathrm{NW}$. in the upper part of the canyon. The Cinnabar Canyon thrust may have followed the folded plane of the Spearmint thrust (pls. 3, 8), along the steeply dipping part near the mouth of Spearmint Canyon for the attitude of the underlying Dunlap is there roughly parallel to the plane, whereas farther east the folds of the Dunlap are moderately truncated and locally overturned. Possibly however, the steepening dip together with the presence here of the opposing West Ridge thrust indicate local impeding of the southward movement.

From near the head of Spearmint Canyon westward to the point where the thrust is concealed beneath the Tertiary lava in Dunlap Canyon (pl. 2), the strike is about west and the dip generally less than $45^{\circ}$.

The Cinnabar Canyon thrust reappears in the southern part of Cinnabar Canyon, south of the area underlain by Tertiary, and follows a general easterly course, dipping $20^{\circ}-30^{\circ} \mathrm{N}$., to the point where it is overlapped by the steeply dipping segment of the East Ridge thrust (pl. 2). The local change of dip on the low ridge 
between Dunlap and Cinnabar Canyons is probably the result of doming by the Tertiary intrusive andesite which occupies a large part of the Tertiary area in Dunlap Canyon.

Movement on the Cinnabar Canyon thrust was probably not large but cannot be directly estimated. The upper part of the Dunlap formation in the lower plate contains coarse conglomerate whose pebbles were derived from the Luning, suggesting that the original northern border of the Dunlap trough may not have been far distant. The distribution of the conglomerate within the slate unit of the Luning formation in the upper plate also suggests a marginal facies and consequently small movement. Above the southernmost outcrop of the thrust, between Dunlap and Cinnabar Canyons, the slate unit is highly conglomeratic and contains large partly subangular chert pebbles. The proportion of conglomerate decreases to the north; and in the northern outcrops of the slate unit, the small and well-rounded pebbles occur in thin, though numerous, beds. The large area underlain by slate north of the 7,900-foot hill north of West Ridge was not studied in detail, but one syncline trending west-northwest was noted south of Dunlap Canyon. An anticline trending northeastward overturned to the southeast, is outlined by the lower limestone, which crops out on the west wall of Dunlap Canyon close to the contact with the Teritary.

East of Dunlap Canyon the folds of the upper plate trend eastward and are overturned to the south. Close to the outcrop of the thrust the transitional beds between the slate and lower limestone units crop out in the core of an overturned anticline. Farther north the upper limestone marks the trough of an overturned syncline, and a parallel overturned anticline with a core of lower limestone is overlapped by the East Ridge thrust (pl. 2).

West Ridge thrust.- On the West Ridge thrust movement was to the north or northeast (pls. 7,8 ). The intense folding of the rocks in the northwestern part of the range indicates that in this area the south ward movement was impeded, and, therefore, minor opposed thrusting on the opposite side of the trough may have taken place at the same time. On the other hand, as the steep western segment of the Cinnabar Canyon thrust lies between the West Ridge thrust and the area of intense folding, the West Ridge thrust may have been a counter movement that resulted from impeding the Cinnabar Canyon thrust.

The thrust has an average northwesterly strike, swinging westward at its northern end, and the dip is generally steep, from $50^{\circ}-75^{\circ} \mathrm{SW}$. The upper plate contains slate and basal conglomerate of the Luning, resting on the Excelsior formation with marked angular unconformity, the lower limestone unit being absent.
On the lower plate the Dunlap is likewise unconformable on the Excelsior. Southeast of Telephone Canyon there is Excelsior on both walls, and the extension of the thrust in this direction was not followed.

The total movement is unknown but is not necessarily large. The fact that in this locality the lowest unit of the Luning formation is slate and conglomerate rather than limestone does not indicate major movement, for the northern plates carrying the limestone as the lowest unit of the Luning moved southward along the Cinnabar Canyon and other thrusts.

E'ast Ridge thrust.-The East Ridge thrust seems to have moved south along a combination of segments, some striking northward and dipping steeply eastward, others striking westward and dipping gently northward (pl. 2). The easternmost of the two major gently dipping segments crops out about 2 miles south of the western, and a northward projection of its plane would be at a considerably lower altitude.

At its most northerly outcrop, east of the lower part of Cimnabar Canyon, the thrust has a northerly strike and steep east dip. The fault trace is obscure where both walls are in lower limestone of the Luning formation, but a belt of intense shearing and contortion in the limestone connects with the northward dipping thrust plane to the east. Eastward nearly to the crest of East Ridge, the thrust has a gentle northerly dip, probably about $20^{\circ}$. Along the wide valley west of East Ridge the upper plate is bordered on the west for over 2 miles by a steeply dipping plane which strikes a few degrees west of north. Later normal faulting may have taken place along this segment, parallel to the normal faults further to the east. The steeply dipping fault plane, however, could not be traced beyond its junctions with the adjoining segments whieh dip gently to the north. The segment crossing East Ridge strikes about N. $60^{\circ} \mathrm{E}$. on the crest of the ridge; and dips about $35^{\circ}$ to the north.

The alternation of steeply and gently dipping segments suggests movement under a light load; and the conglomerate of the Dunlap above the slate on the crest of East Ridge indicates erosion of the upper part of the Luning prior to thrusting and, therefore, movement of a relatively thin plate. There is, however, no direct evidence of movement over an actual erosion surface such as is furnished by the thrust conglomerate on the plane of the New York Canyon thrust in the Gabbs Valley Range. The stepping down to the east along the steeper segment may be the result of continued uplift of the area of early thrusting and close folding in the northwest corner of the range.

The rocks of the upper plate are less intensely folded than those of the lower thrust plates in the northwestern part of the range. The lower limestone in the western 
segment of the upper plate is compressed into an anticline overturned to the south (sec. $H-H^{\prime}$, pl. 2). The structure of the upper plate on East Ridge and along the east front of the range was not studied in detail. At least the larger of the slate belts may represent the keels of synclines overturned to the south; if so, there must be complementary anticlines in the limestone. To some extent, however, the slate and limestone intertongue. The slate to the north overlies the lower limestone and dips moderately northward to northwestward except through a short distance where the upper slate has overridden the limestone for about 2,000 feet along a small thrust whose plane bends sharply from a gentle northerly dip to nearly a vertical attitude. The upper limestone north of the slate shows a series of open folds with easterly trend.

It is likely that the downwarp in the northern part of the range, partly concealed by Tertiary and Pleistocene formations (sec. $H-H^{\prime}$, pl. 2), is an extension of the syncline in Cedar Mountain, 6 miles to the east.

Movement on the East Ridge thrust is believed to have been of greater magnitude than on the lower thrusts. The most southerly outcrop is about 3 miles distant from the most northerly; but it is probable that the total movement was considerably greater, as the rocks of the upper plate are less folded than those below the thrust. The different lithology of the two lower units of the Luning in the upper and lower plates also suggests considerable movement on the thrust. In the lower plate the lower limestone unit is shaly and thinbedded, but near the top in a zone about 200 feet thick, massive beds of blue-gray coral-bearing limestone attain a maximum individual thickness of about 50 feet. Above the thrust the lower limestone is on the whole more massive, and the coral-bearing beds are less well defined than in the lower thrust plates and are not as definitely concentrated in the upper part of the limestone unit. In the lower plate the slate unit of the Luning consists of a brown to dark-gray silicious slate and argillite containing varying amounts of conglomerate, a little quartzite, and a few thin limestone beds. The increase southward in amount of conglomerate and in the size of the chert pebbles suggests near-shore deposition. Above the East Ridge thrust, on the other hand, the slate member contains only a few conglomerate lenses, and the upper 500 feet is composed of fossiliferous gray slate containing calcareous layers, a facies not present in the slate unit in the lower thrust plates. The transition to the upper limestone unit is also more gradual than below the thrust. Identity of the East Ridge thrust with the New York Canyon thrust of the Gables Valley Range (sec. $G-G^{\prime}$ and $H-H^{\prime}$, pl. 2) seems a reasonable assumption, but is not capable of proof.

\section{NORMAL FAULTING}

The present relief of the range is the result of Tertiary and Quaternary faulting. Both the east and west fronts are fault scarps, the western being the simpler and higher.

The downthrown block of the fault along the west front is exposed only south of Telephone Canyon (pl. 2) where Dunlap resting on Excelsior at the base of the scarp indicates vertical displacement of at least 1,500 feet. To the north the fault scarp ends abruptly at Mac Canyon, but Tertiary or Quatemary movement probably occurred on the two northeastward-striking faults west of the 6,500-foot hill; though these faults probably originated during the earlier movement on the Northwest thrust (p. 34). A late normal westward-trending fault forms the boundary between the Mesozoic and Tertiary in the lower part of Cinnabar Canyon. A parallel fault to the north involves Pleistocene gravel, but no similar normal faults were found within the area underlain by Mesozoic rocks.

Tertiary lavas are faulted against the older rocks along most of the eastern front of the range; and the normal faults within the Mesozoic rocks of the East Ridge are also probably of Tertiary age, though, in part, this later movement may have taken place along older fault planes including possibly the steeply dipping segment of the East Ridge thrust.

The northwestward-striking fault along the east flank and crest of East Ridge (pl. 2) is a normal fault whose essentially vertical downthrow on the east is indicated by the drag on both walls and the lack of any significant thrusting in the block to the east. The displacement decreases sharply to the south. A throw of 4,000 feet or more at the northern border of the preTertiary is indicated by the displacement of the northward-dipping contacts of upper limestone and slate; this decreases to 1,500 feet at the contact of slate and lower limestone a mile to the south, to not more than 300 feet where the slate bands cross the lower limestone on the crest of the ridge, and the displacement fades out near the 8,900-foot peak.

The Tertiary andesite overlaps the older rocks immediately east of this fault; but a short distance farther east the andesite is in fault contact with the Luning. This fault, over most of its traced extent, strikes about west, but at its eastern end near Graham Spring the strike swings sharply to the south. To the west, several smaller faults striking N. $30^{\circ}-70^{\circ} \mathrm{W}$. displace the contact of slate and limestone. A mile to the east at Graham Spring there is an isolated area of the upper limestone unit of the Luning along the front of the small scarp bordering Stewart Valley. Slight movement on this fault in the 1932 earthquake greatly increased the flow of the spring. 
The two parallel normal faults in the central part of the range near the head of Dunlap Canyon (pl. 2) may be of pre-Tertiary age for they do not offset the contact of the Tertiary rocks and are not found north of the area underlain by Tertiary. The western fault may have determined the position of the andesite intrusion which lies along its northern extension. The clifflike promontory of the Excelsior where it is in contact with the Dunlap formation (p. 31) just west of the western fault suggests that it may be the result of renewed movement on a fault plane which was in existence at the time of Dunlap deposition.

\section{CEDAR MOUNTAIN}

Cedar Mountain (pl. 1) lies east of the Pilot Mountains and the southern part of the Gabbs Valley Range, and south of the Paradise Range. The geology is known only from reconnaissance. Two areas are underlain by pre-Tertiary rocks.

\section{ROCKS EXPOSED}

The Excelsior formation crops out only in the south. ern part of the range, east of the southern Pilot Mountains. Greenstone appears to overlie chert, which dips to the south.

The Luning formation in the northern part of the range consists principally of limestone, which is probably equivalent to the upper limestone unit of the Luning in the Pilot Mountains. The present study has shown that the fossils formerly regarded as Middle Triassic are of Upper Triassic age and belong to the Luning formation. The Luning formation south of the southem granodiorite mass, consists of 2,500-3,000 feet of argillite interbedded with quartzite and conglomerate and overlain by an equal or somewhat greater thickness of limestone. The lower part of the limestone is somewhat shaly, the upper part is more massive and, in places, grades into dolomite near the top.

Knopf ${ }^{18}$ has reported a pre-Tertiary lava, the Simon quartz keratophyre, associated with the Triassic sediments in the vicinity of the Simon mine in the northern part of the range and cut by porphyry and aplite dikes. This appears to be a fine-grained intrusive rock similar to others characterized by nearly aphanitic texture referred to as aplite in this report; but the field relations are obscure, and this rock may be a lava flow within the Luning. It can hardly be a part of the Excelsior unless the structure is completely overturned, for Knopf's section through the Simon mine shows the quartz keratophyre overlying limestone.

The Dumlap formation rests on the Luning in a narrow syncline at the southern end of the northern area. and also crops out in the southern part of the range

\footnotetext{
${ }^{18}$ Knopf, Adolph, Ore deposits of Cedar Mountains, Mineral County. Nevada: U. S. Geol. Survey Bull, 725, p. 363, 1921.
}

where it rests on Excelsior. In th.e northern area the Dunlap consists largely of red seindstone, red sandy shale, and a little limestone conglomerate near the base. No fanglomerate or thick conglomerate unit is present. Red sandstone is predominant likewise in the southern areas underlain by the Dunlap but here the conglomerate is composed principally of chert pebbles, and there are also thin beds of limestone.

Besides the granodiorite, which forms the principal intrusive masses, there are a large number of porphyritic and fine-grained dikes, both silicic and basic. Those in the vicinity of the Simon mine, in the northern part of the range, have been described by Knopf. ${ }^{19}$

\section{STRUCTURE}

Scattered observations on the Luning in the northern part of the northern area suggest rather gentle folding trending generally northwest. Southward the folds seem to be steeper, and one possible minor thrust was noted. According to Knopf, ${ }^{20}$ the ore body of the Simon mine follows a steep reverse fault along which a dike of alaskite porphyry was intruded prior to mineralization. In the southern part of the northern area the prevailing trend is westerly. The principal syncline contains the Dunlap and is in part overturned to the north, contrary to the general direction of overturning in the Pilot Mountains. The dip on the overturned southern limb is at one place as flat as $20^{\circ}$ with minor overthrusting near the western end but steepens to about vertical within short distances to the east and west. The alinement of the syncline with the parallel folding in the Pilot Mountains to the west and in the hills 8 miles to the east suggests continuity of folded structure beneath the Tertiary and Quaternary deposits.

In the southern area the Dunlap above the Excelsior is highly folded. Northwesterly trends seem to prevail, but at one place Excelsior overlain by Dunlap is apparently thrust from the north over the Dunlap formation.

Faults of premineral and postmineral age are present in the Simon mine, ${ }^{21}$ whose ores are probably preTertiary; and, over much of the northern area, the abundance of silicified zones in the limestone of the Luning suggests that there is considerable local faulting within the Mesozoic rocks. Tertiary faults bound the area of Mesozoic rocks along a part of the west flank of the range. Knopf ${ }^{22}$ noted the fault border of the Tertiary rolcanics near Simon and the major northwarddipping fault within the Tertiary lavas on the ridga to the north. The complex faulting in the Simon mine ${ }^{23}$ is of postmineral age. The numerous zones

\footnotetext{
19 Inopf, Alolph, op cit., pp. 365-366.

${ }^{20}$ Knopf, Adolph, op. cit., p. 370.

${ }^{21}$ Knopf, Adolph, op. cit., p. 375.

${ }^{22}$ Knopf, Adolph, op. cit., pp. 367-368.

${ }^{23}$ Knopf, dtolph, op. cit., pp. $375-376$.
} 
of silicified limestone within the Luning formation south of Simon probably mark the outcrop of Tertiary faults; these in part follow the northwesterly trends of the faults bordering the range and in part are elongated parallel to the major eastward-striking fault. Knopf ${ }^{24}$ also described a rever'se fault of 300 feet or more displacement in the Tertiary rocks at the Olympic mine, 3 miles north of Simon. Gianella and Callaghan ${ }^{25}$ find that movement on the 1932 earthquake rifts was largely horizontal with the Cedar Mountain block moving relatively southward with respect to the Pilot Mountains and Gabbs Valley Range. The approximate alinement of structures in the Cedar Mountain with those in the Pilot Mountains, howerer, offers some evidence that this displacement probably camnot be attributed to renewed horizontal movement on a major flaw, such as is inferred to be present in Soda Spring Valley (p. 14).

\section{AREAS OF MESOZOIC ROCKS EAST OF CEDAR MOUNTAIN}

The Luning formation that crops out in the low hills between Cedar Mountain and the southern end of the Shoshone Mountains (pl. 1) appears to contain two units, the lower consisting principally of conglomerate and slate, the upper of dolomite and limestone. A notable feature of the conglomerate is the large size of the pebbles, which reach as much as a foot in diameter. These consist almost entirely of light-colored chert, suggesting derivation from cherts in the Permian volcanics rather than from the Excelsior in which darker colors prevail. Dolomite appears to be more abundant than limestone in the upper calcareous unit.

Granitic igneous rocks crop out in several small areas, and there is widespread metamorphism of the Luning formation.

No detailed study was made of the structure, but scattered observations show generally steep northerly dips in the southern part of the area underlain by the Luning formation. The rocks dip variably but predominantly westward in the central part, and gently southward at the north. In most places the slate and conglomerate lie at the outer margin of the crescentshaped area and limestone and dolomite in the central part; therefore, the major structure is inferred to be a westward-pitching syncline having a steep southern limb. This roughly accords with the position in Cedar Mountain of a similar syncline in which the Dunlap formation overlies the Luning.

There is another small area of Mesozoic rocks at the south end of the Toyabe Range (pl. 1). The eastern part of this area consists of Permian (?) chert dipping steeply northeast. On this the Dunlap formation rests

\footnotetext{
${ }^{24}$ Knopf, $\Lambda$ dolph, op. cit., pp. 381-382.

${ }^{25}$ Gianella, V. P., and Callaghan, Eugene, The earthquake of December 20, 1932, at Cedar Mountain, Nevada, and its bearing on the genesis of Basin Range structure: Jour. Geology, vol, 42, pp. 1-22, 1934.
}

with marked angular unconformity and general northwesterly dip. The Dunlap formation here consists largely of red sandstone but contains at the base conglomerate composed of chert pebbles and in the upper part conglomerate of limestone pebbles derived from the Luning. Limestone of the Luning is thrust over the Dunlap in the extreme northwest corner of the exposed area. The thrust plane dips northwest and the trace is exposed for a short distance only.

\section{PARADISE RANGE}

Through nearly its entire length within the northwestern part of the Tonopah quadrangle the Paradise Range is underlain by pre-Tertiary rocks. Granitic rocks outcrop over large areas and consequently the surrounding sedimentary rocks are much metamorphosed. Study by the writers was confined to the vicinity of Paradise Peak with reconnaissance traverses along the trace of the Paradise thrust northward to a point near Downeyville, and along the ridge east of Downeyville. The geology of a small area surrounding the brucite deposit in the western part of the range had at that time been studied in detail by Callaghan. ${ }^{20}$

Since completion of field work by the writers, geologic mapping of the 15-minute quadrangle including the Paradise Range has been completed by Eugene Callaghan and Charles J. Vitaliano, and a detailed geologic map of this quadrangle is in preparation. As a result of this work many changes in the early reconnaissance mapping became necessary. The major errors and omissions were kindly indicated to the senior writer by Mr. Vitaliano on the ground in the summer of 1947 . The principal ones inclucle the outcrop of the Paradise thrust west and southwest of Paradise Peak, the presence of a slate unit in the upper plate of this thrust, normal faults in the central part of the range, the presence of Permian quartzite on the east flank of the range and extension of the outcrop of the overlapping thrust in the southern part of the mapped area.

\section{ROCKS EXPOSED}

\section{PERMIAN (?) VOLCANIC AND SEDIMENTARY ROCKS}

The oldest rocks of the Paradise Range are dominantly rolcanic and are tentatively referred to the Permian because the rocks are similar to those in the volcanic formation that underlies the Middle Triassic Grantsville formation in the neighboring Shoshone Mountains. Greenstones and greenstone breccias are abundant; but along the west front of the range between Lodi Tanks and Green Springs, there is also much bedded material including chert, tuff, slate, sandstone containing a little conglomerate, and thin beds of limestone and dolomite.

${ }^{26}$ Callaghan, Eugene, Brucite deposit, Paradise Range, Nevada: Nerarla Unir. Bull., vol. 27, no. 1, 1933. 
A considerable area underlain by quartzite with some limestone on the east flank of the range has been mapped by Callaghan and Vitaliano. It is probable that this is the sedimentary member of the Permian below the volcanics.

\section{MESOZOIC ROCKS}

Excelsior formation (?).-Greenstone forms the upper plate of a thrust at the southern end of the range and is also thrust over slate of the Luning formation on the west flank of the range, south of Downeyville. This is tentatively assigned to the Middle Triassic Excelsior formation because it is believed that major movement along the thrusts was from the west. Isolated areas of greenstone crop out in the northern part of the Hawthorne quadrangle ( $\mathrm{pl} .1$ ) between the Paradise Range and the Gillis Range, 35 miles to the west, where the greenstone is known to be of Middle Triassic age.

Luning formation.-Below the Paradise thrust in the vicinity of Paradise Peak three lithologic units have been mapped: Lower limestone, gray to black, thinbedded, over 2,000 feet; slate with a little conglomerate, about 1,000 feet; upper limestone and dolomite, white, massive, crystalline, 500 or 600 feet. Slate, dolomite, and limestone are also present on the ridge east of Downeyville.

Above the thrust there is massive dolomite apparently several thousand feet thick, overlying an unknown thickness of slate. Callaghan and Vitaliano have found that the dolomite in places grades into limestone, so it is not known to what extent it may be the result of secondary dolomitization along the thrust.

Gabbs and Sunrise formations.-The Gabbs and Sunrise formations consist of the usual thin-bedded limestones and slates, the Sunrise formation containing perhaps a larger proportion of sandstone than at the type locality in the Gabbs Valley Range. In the northern part of the range northeast of Downeyville, the Gabbs and Sunrise formations overlie the Luning, and in the isolated low ridge at the south end of Lodi Valley a small area is underlain by the Gabbs formation in fault contact with the Luning.

Dunlap formation.-The Dunlap formation, consisting of red sandstone interbedded with conglomerate, crops out only in the northern part of the range on the ridge south of Lodi Valley where it is overthrust by Luning.

\section{INTRUSIVE ROCKS}

Large intrusive masses composed of aplite, granodiorite, quartz diorite, monzonite, and diorite, as well as a wide variety of porphyritic dikes cut the earlier formations; and alteration due to igneous metamorphism is widespread.

\section{STRUCTURE}

At least two major thrusts are present. A dolomitic facies of the Luning formation is thrust over the Lun- ing, Gabbs, and Sunrise formations and is in turn overthrust by greenstones regarded as belonging to the Excelsior formation. Movement of the upper plates was probably to the eastward and is believed to have been of considerable magnitude.

Paradise thrust.-The Paradise thrust crops out in the southwestern part of the range. Dolomite with minor limestone and slate, belonging to the Luning formation, and possibly greenstone assigned to the Excelsior, are thrust over the Luning which consists of limestone, with minor dolomite and slate, and, at Paradise Peak, over the Gabbs and Sunrise formations. 'The difference in facies of the Luning in the upper and lower plates suggests that movement probably far exceeded the 6-mile east to west breadth of outcrop. The dip of the thrust is westerly, probably averaging less than $10^{\circ}$, but ranges from about horizontal at the northern end of the klippe northwest of Paradise Peak to a maximum of $26^{\circ}, 11 / 2$ miles to the north.

The folds in the Luning, Gabbs, and Sunrise formations below the thrust generally trend to the north, with overturn to the east and broken by small thrusts in the northern part (Sec. $A-A^{\prime}$, pl. 11) but are more open to the south, near Paradise Peak (Sec. $C_{-} C^{\prime}$, pl. 11). South of the peak, the trend is easterly with overturn to the south. (Sec. $B-B^{\prime}$, pl. 11.)

The Permian is in fault contact with the Luning formation and its structure was not studied.

The massive dolomite of the upper plate shows moderate dips, but the structure was not studied in detail. The general trend of the folds is northerly, and according to Callaghan ${ }^{27}$ the prevailing dip in the northern part is $20^{\circ}-40^{\circ} \mathrm{W}$. The elongate area underlain by slate in the south, west of Paradise Peak, suggests a northeast trending anticline. In the klippe (sec. $C-C^{\prime}$, pl. 11) northwest of Paradise Peak, the rocks dip north and northwest in the southern part, and south west in the northern part.

South thrust.-The thrust which crops out at the southern end of the range was not studied. Greenstones assumed to belong to the Excelsior formation are thrust over both plates of the Paradise thrust. The thrust that carries greenstone over the Luning formation on the west front of the range, south of Downeyvilie may be a part of this thrust. The Gillis thrust, whose nearest outcrops are 30 miles to the west and southwest, also carries Excelsior above Luning and overlaps earlier thrusts.

\section{SHOSHONE MOUNTAINS}

The Shoshone Mountains (pls. 12,13) and the larger Toyabe Range to the east form a single mountain block in the northern part of the Tonopah quadrangle. The two ranges are separated by a depression draining northward through Reese River Valley and southward

${ }^{27}$ Callaghan, Eugene, op. cit., p. 18. 
through the valley of Cloverdale Creek (pl. 1). Along the western front is an ill-defined scarp bordered in places by a rock pediment of varying width.

The pre-Tertiary rocks of the Shoshone Mountains occupy a belt 12 miles long and 2 miles wide along the west front of the range, extending southward from a point a mile north of Ione. There are also small isolated areas of pre-Tertiary rocks near the crest of the range. Detailed study was confined to the southern 7 miles of the main belt. The remainder of the preTertiary area is known only from reconnaissance.

\section{ROCKS EXPOSED}

PERMIAN (?) ROCKS

Sedimentary rocks.-Sedimentary rocks lithologically similar to the Permian of the Toyabe Range crop out in two small areas, one on the east flank of the range about 4 miles east northeast of Ione, and the other on the west flank a mile east of Ione. In the eastern area, interbedded slate, conglomerate, and impure quartzite attain a thickness perhaps in excess of 500 feet. In the western outcrops, near Ione, 300 to 400 feet of limestone overlies a somewhat greater thickness of fine-grained quartzite, and greenstone overlies the limestone.

Volcanic rocks.-The Permian (?) sedimentary rocks are overlain by a considerable thickness of dominantly volcanic rocks, which are believed to be of the same age as similar rocks that orerlie conformably fossiliferous Permian strata in the neighboring Toyabe Range. In the Shoshone Mountains these volcanics are overlain with marked unconformity by Middle Triassic Grantsville formation.

North of Berlin the thickness of the volcanic rocks may be as much as 3,000 feet, and more than 1.000 feet are exposed in the area north of Grantsville. The rocks include greenstone lava and breccia apparently derived from andesite, felsitic lava, considerable chert, and some interbedded slate and conglomerate. Several pebbles of a medium-grained granitic rock were noted in the greenstone breccia near Berlin.

\section{MESOZOIC ROCKS}

Grantsville formation.-The Grantsville formation of Middle Triassic age has been recognized only in the Shoshone Mountains. The formation contalins two units, the lower consisting of conglomerate and slate, and the upper of limestone. The thickness varies in different parts of the area. In Grantsville Canyon the total thickness is not more than 400 feet of which the upper 100 feet is limestone, whereas north of Union Canyon the conglomerate and slate is about 500 feet thick and the limestone 300 feet. The conglomerate and slate member increases in thickness northeast ward.

Luning formation.-Two facies of the Luning are present, above and below the Shoshone thrust. In the upper plate the formation consists of massive gray dolomite and limestone. Dolomite appears to be considerably in excess of the limestone but is in part secondary. The thickness could not be closely determined but exceeds 3,000 feet. In the lower plate of the thrust, two units can be distinguished; slate and conglomerate, about 500 feet thick, overlain by about 2,000 feet of limestone.

Gabbs and Sunrise formations.-These formations are present only in the lower plate of the thrust; the Gabbs formation crops out principally in the Union Canyon area, the Sunrise, south of Milton Canyon. Both formations are lithologically similar to those of the type section in the Gabbs Valley Range and consist essentially of thin-bedded limestone and shale. No complete section of either is present, but probably their thickness does not differ greatly from that of the type section : 420 feet for the Gabbs and 1,240 for the Sunrise.

Dunlap formation.-The Dunlap formation crops out in two small areas south of Milton Canyon. In the larger area Dunlap, principally red sandstone with a little conglomerate, overlies the Sunrise and is overthrust by the Luning formation. The second patch at the extreme south of the area of Mesozoic sediments is not more than 200 feet in length and exposes conglomerate composed of dolomite pebbles derived from the Luning. On the north this outcrop is overthrust by the Luning formation, and on the south overlain by Pleistocene gravel.

\section{INTRUSIVE ROCKS}

Pre-Tertiary intrusives occupy small areas. North of Ione is a small exposure of granodiorite. A large dike of diorite intrudes the Permian (?) south of Ione, and a few small granite and diorite bodies cut the Permian (?) between Ione and Berlin. At the east end of Grantsville Canyon, fine-grained white aplite cuts the Permian (?) volcanic rocks, the Grantsville formation, and the lower part of the Luning. Quartz monzonite cuts the Luning south of Grantsville.

\section{STRUCTURE}

The Permian (?) volcanic rocks were folded before the deposition of the Middle Triassic Grantsville formation. An erosional unconformity separates the Grantsville and Luning, but there is no indication that significant folding occurred between the deposition of the sediments in the two formations.

The Shoshone thrust carried overturned Luning above the Gabbs and Sunrise formations. Movement was to the west or southwest, contrary to the prevailing direction in other parts of the two quadrangles underlain by the Luning formation, though accordant with the direction of thrusting of Ordovician over Permian, in the Toyabe Range, 15 miles to the northeast. There has been complex faulting later than the thrusting in the area north of Grantsville Canyon, underlain by the 
lower plate of the thrust. That along Grantsville Canyon was in the reverse direction bringing the lower plate rocks against those of the upper plate of the thrust. Dominantly horizontal movement is suggested for the Union Canyon fault. Major movement on these as well as on the normal faults appears to have been prior to the Tertiary lavas but there may have been renewed movement on the Richmond Hill fault and possibly along the western segment of the Union Canyon fault during Tertiary or later faulting.

Pre-Jurassic folding.-The Permian (?) rocks were not studied in detail. South of Ione a syncline is suggested by a belt of chert containing some interbedded conglomerate trending west of north and bordered on both sides by greenstone and greenstone brercia.

The contact of the Grantsville formation with the Permian (?) is marked in places by a basal conglomerate containing pebbles derived from the immediately underlying greenstone or felsite. More commonly 10 to 40 feet of purplish slate forms the base of the Grantsville and probably represents reworked material from the weathered surface of the underlying lava. Above the basal beds, however, the conglomerate, which forms more than half of the lower member of the Grantsville, contains only chert pebbles. The nearest source is the belt of chert in the Permian (?) south of Ione.

No angular unconformity is evident between the Grantsville and Luning formations, but it seems likely that the Grantsville was broadly warped prior to the deposition of the Luming. The thickness of the limestone member of the Grantsville decreases from 300 feet, north of Union Canyon, to about 100 feet in Grantsville Canyon, 2 miles southeast. In places an irregular and discontinuous zone, as much as 10 feet thick, at the upper contact, is silicified, possibly due to surficial alteration before the deposition of the Luning formation. The conglomerate of the lowest unit of the Luning contains pebbles of Permian (?) chert as much as 6 inches in diameter, which is larger than those in the conglomerate of the Grantsville, therefore, either overlap or local erosion of the Grantsville prior to the deposition of the Luning is inferred.

Shoshone thrust.-The Shoshone thrust carries massive dolomite and limestone of the Luning formation to the west above the Gabbs and Sumrise formations which overlie the more typical thin bedded limestone and slate of the Luning of the lower plate. Two segments are exposed; the northern, between the forks of Union Canyon, is cut off to the south against the Union Canyon fault. Further to the south reverse faulting along Grantsville Canyon brings the lower plate formations against the upper plate dolomite and limestone forming Grantsville Ridge and the thrust plane is again exposed in Milton Canyon. South of Milton Canyon, there are klippen partly concealed by Tertiary lavas.
The northern segrment of the thrust is inconspicuous as the $25^{\circ}$ eastward dip of the thrust nearly coincides with the dips of the strata on both upper and lower plates, and the outcrop is largely masked by talus from the massive Luning of the upper plate. The small segment of upper plate shows a homoclinal easterly dip. The major structure of the highly faulted lower plate appears to be a northward trending anticline whose axis is marked by the belt of Permian voleanics west of Richmond Hill, bordered by a faulted syncline containing the outcrop of the Gabbs formation south of Union Canyon.

In the souther'n part of the area, south of Grantsville Canyon, on the other hand, the rocks of both plates are highly folded, but the structure could not be worked out in detail. The massive dolomite and limestone of the upper plate is in part overturned to the west. The Sumrise formation which underlies the greater part of the exposed area of the lower plate is highly folded and in part overturned to the west, especially near the thrust. Near Milton Canyon its prevailing strike is about northwest; in the southern part, nearly north.

The thrust, where it is cut by Milton Canyon, dips about $35^{\circ} \mathrm{E}$. To the west along the north wall, the plane is warped so that for a short distance along its outcrop the thrust has a westerly strike and gentle northerly dip. Along the range front it strikes north and dips gently east. South of Milton Canyon, klippen of the dolomite of the Luning, partly obscured by Tertiary lavas, indicate that the plane undulates and has an average gentle westerly dip (sec. $G-G^{\prime}$, pl. 12). That the upper plate moved to the west or southwest is shown by the prevailing overturn of the overridden Sumrise formation near the thrust. Such overturned beds $\operatorname{dip} 30^{\circ}-60^{\circ} \mathrm{E}$. and $\mathrm{NE}$.

The peculiar "spike" of dolomite of the Luning formation intruded into the Sunrise of the south wall of Milton Canyon (pl. 10) is difficult to explain. The irregularity is probably less than is suggested by the photographs because the angle between the thrust plane and the eastern slope of the hill may not be large. The dolomite, in this place rather less massive than usual, is in fault contact with the Sunrise whose overturned strata dip $40^{\circ}-60^{\circ} \mathrm{E}$. On the other hand, there is no shear plane between the spike and the main mass of the dolomite, and individual beds can be followed around the reentrant to the thrust plane on the lower side of the spike. Therefore, the spike cannot be attributed to imbricate thrusting but must have formed as a result of the different competency of the rocks in the two plates, a small fold in the dolomite having actually been forced into the soft Sunrise formation and later sheared along the lower surface of the "spike."

The maximum distance from east to west between outcrops of the Shoshone thrust, is about 2 miles but the different facies of the Luning formation in the up- 


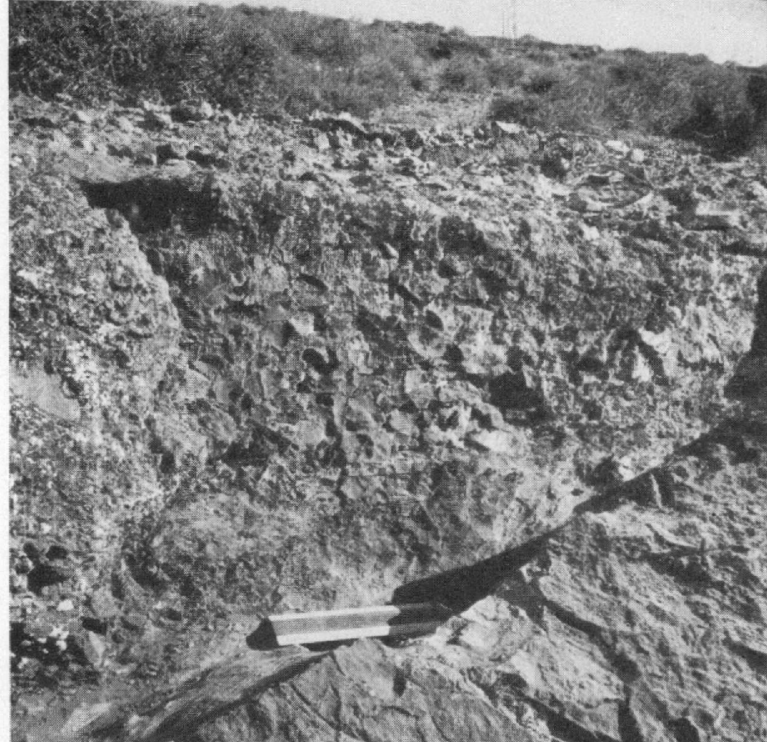

A, "THHUST CONGLOMERATE" ON RIDGE SOLTH OF SLN. RISE FLAT, GABBS VALLEY RANGE.

Shows close packing of pebbles and lack of stretching and shearing.

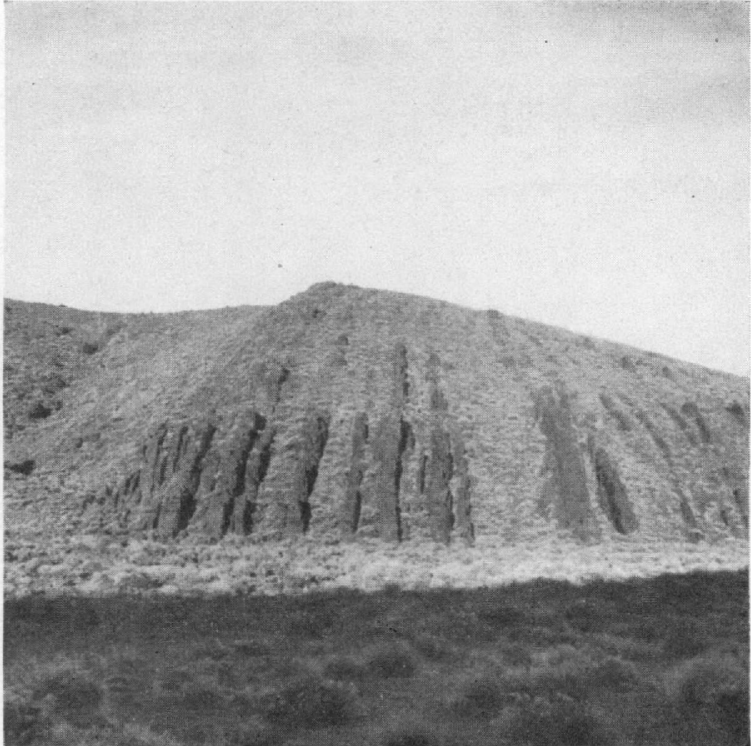

$B$, ITTERBEDDED CHERT WITH TLFFACEOLS SLATE AND SANDSTONE IN EXCELSIOR FORMATION. South flank of Pilot Mountaine.

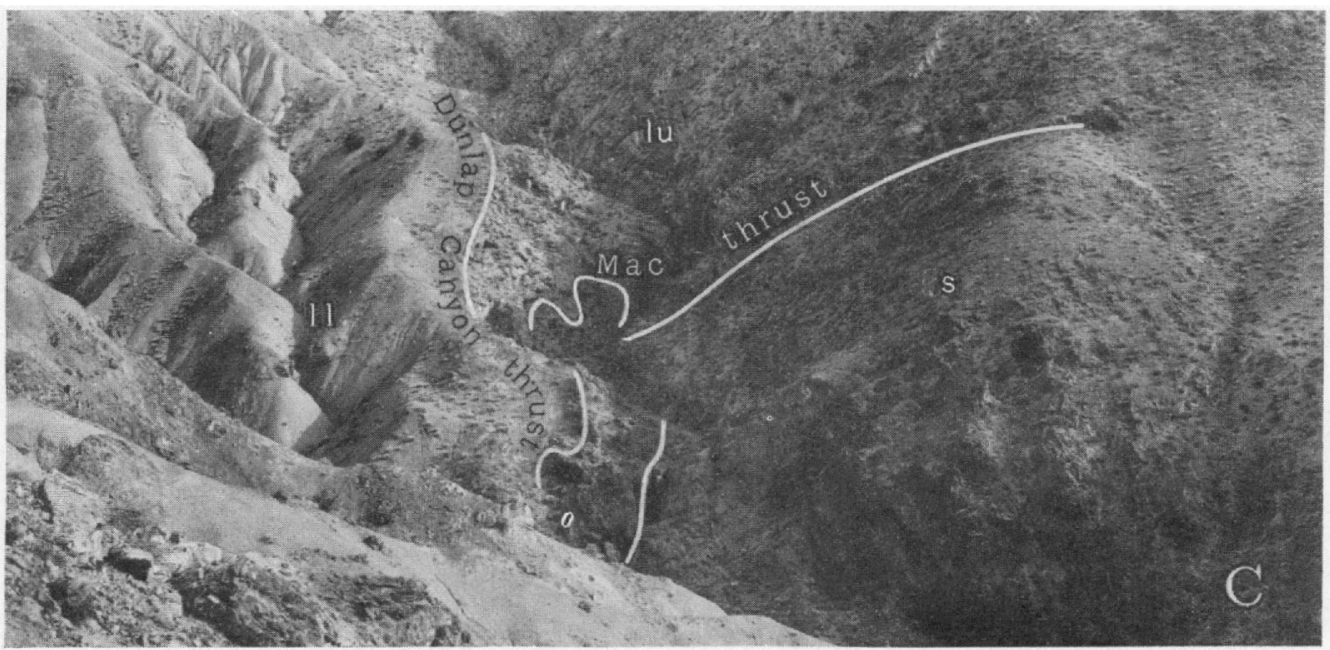

C, UPPER PART OF MAC CANYON SHOWING BEND IN MAC THRLST.

The Dunlap Canyon thrust (left) here overlaps the Spearmint thrust.

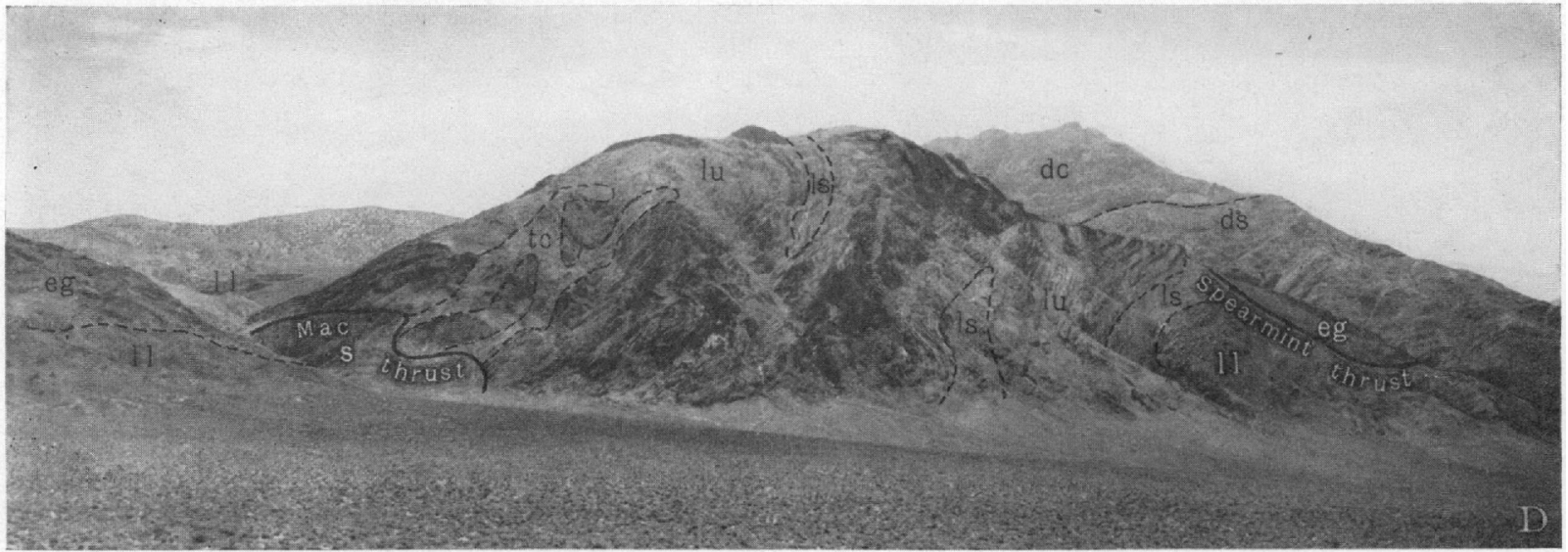

D, HILL BETWEEN MAC AND SPEARMINT CANYONS, WEST FRONT OF PILOT MOLNTAINS.

Shows overturned part of Mac thrust and conglomerate along the thrust plane. Crumpled upper limestone of Luning formation forme the upper plate, which is overturned near the Mac thrust. Photograph by Elivt Blackwelder.

Dunlap formation: $t c$, thruet conglomerate; $d c$, conglomerate; $d s$, Bandstone. Sunribe formation, $s$. Luning formation: $l u$, upper limestone; $l s$, slate; $l l$ lower limestone. Excelsior formation: eg, greentone. 


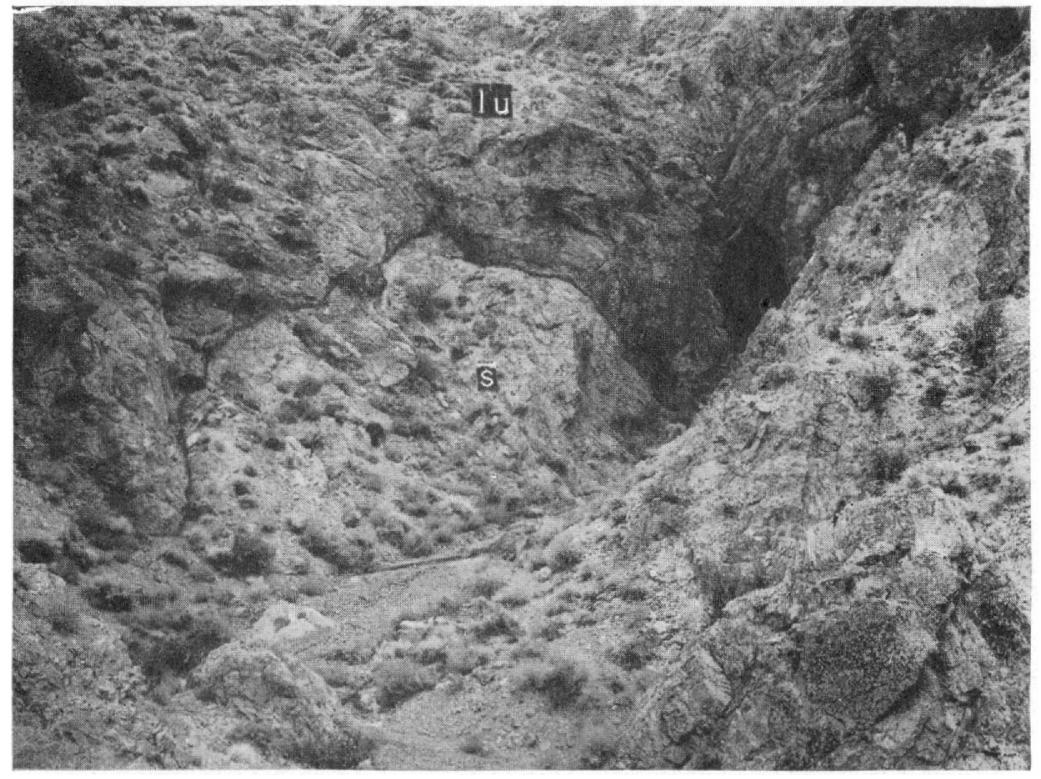

A, CORRUGATIONS IN MAC THRUST AT BEND, CPDER PAR'T OF MAC CAVYON. Luning formation: $l u$, upper limestone. Sunrige formation, $s$.

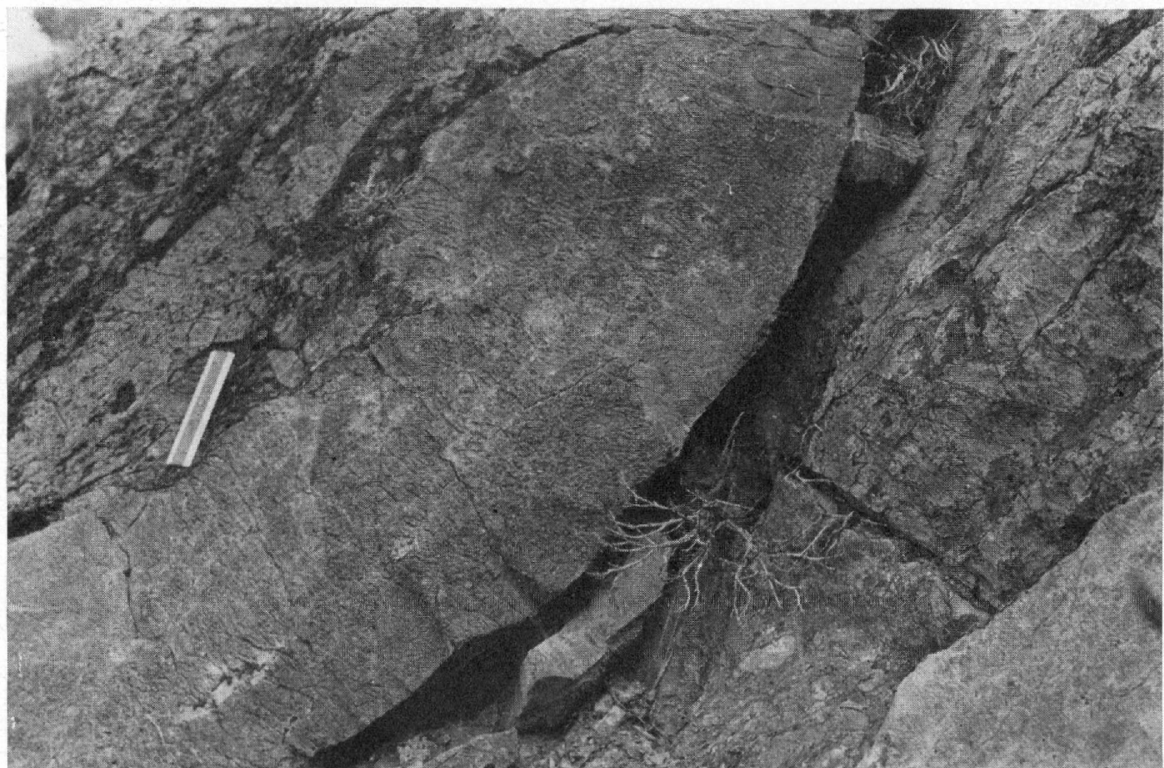
OF MAC THRUST.

Ridge south of Mac Canyon, Pilot Mountains.

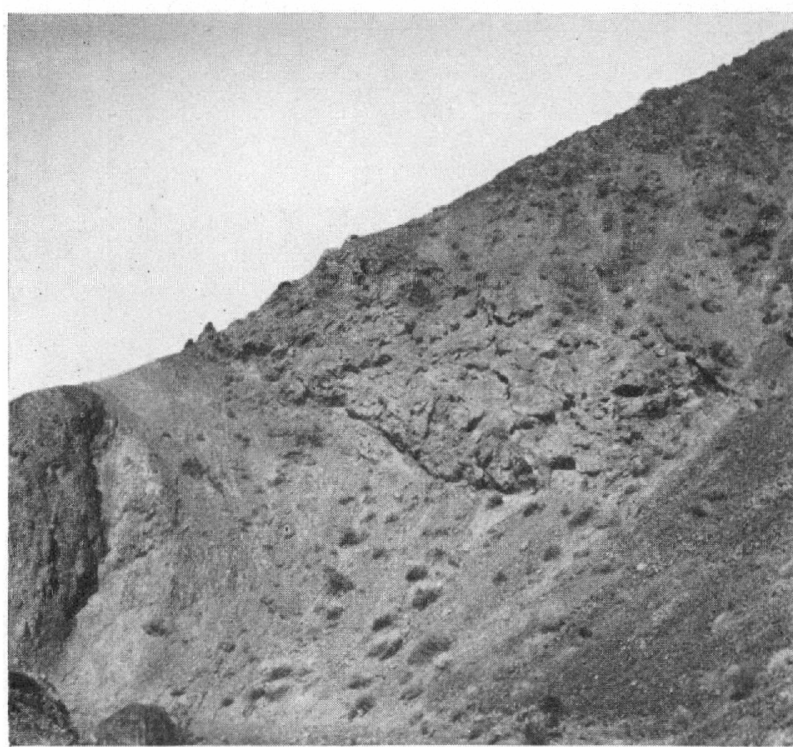

C, BRECCIATED DOLOMITE, IN UPPER UNIT OF LUNING FOR MATION, BETWEEN MAC AND SI'EARMINT TIHUSTS.

North wall of Mac Canyon, Pilot Mountains. 'The dolomite crops out in a
prominemt hand (center of photograph) and is loounderl by the Mac thrust

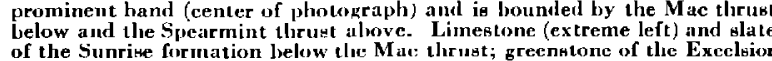
of the Sunrime formation below the Mation
formation above the Spearmint thrubl.

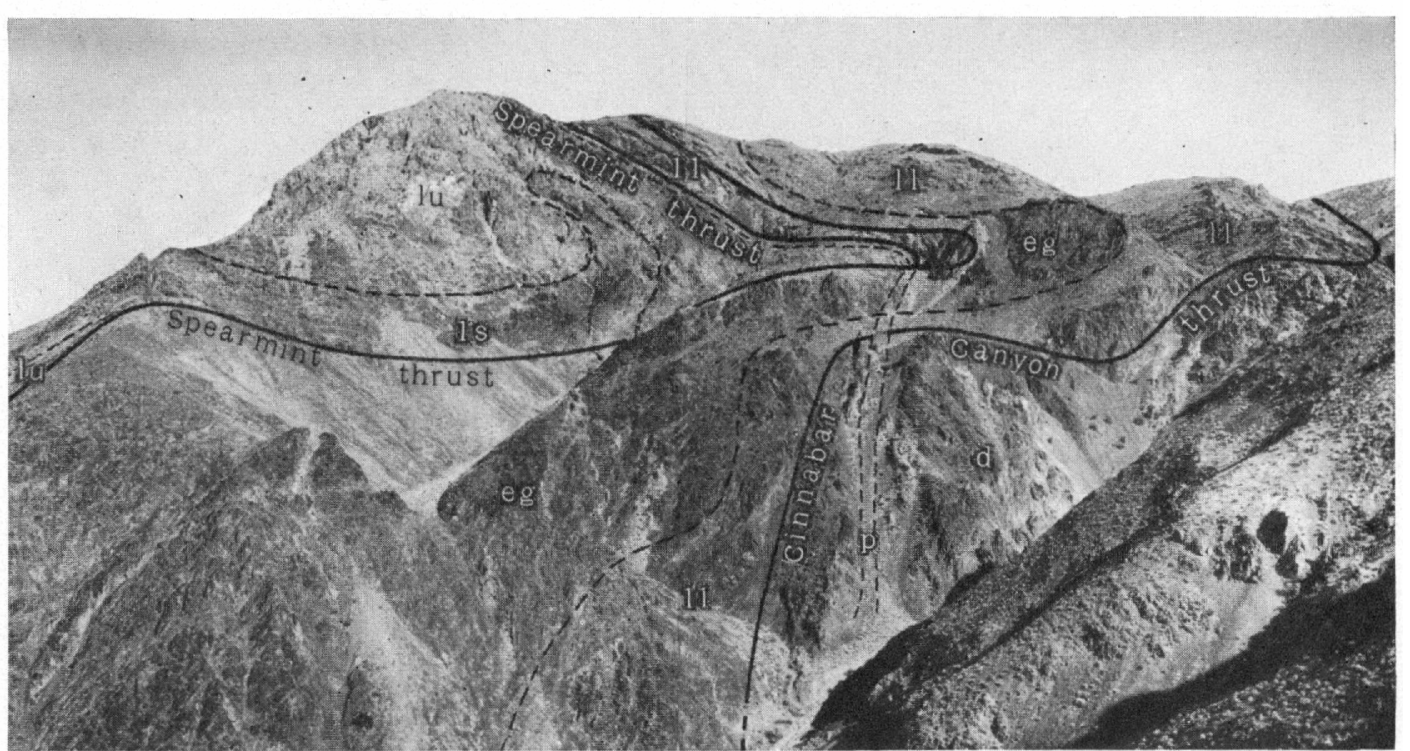

D, NORTII WALL OF SPEARMINT CANYON, PILOT MOUNTAINS.

Shows outerops of Spearmint and Cinnabar Canyon thruats.

P. periodutite dike; Dunlap formation: $\lambda$, conglomerate and sandstone. Luning formation: $l u$, uppiper limestone; $l s$, aliate; $\| l$, lower lime-

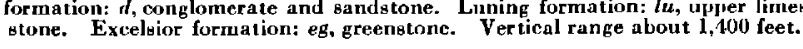




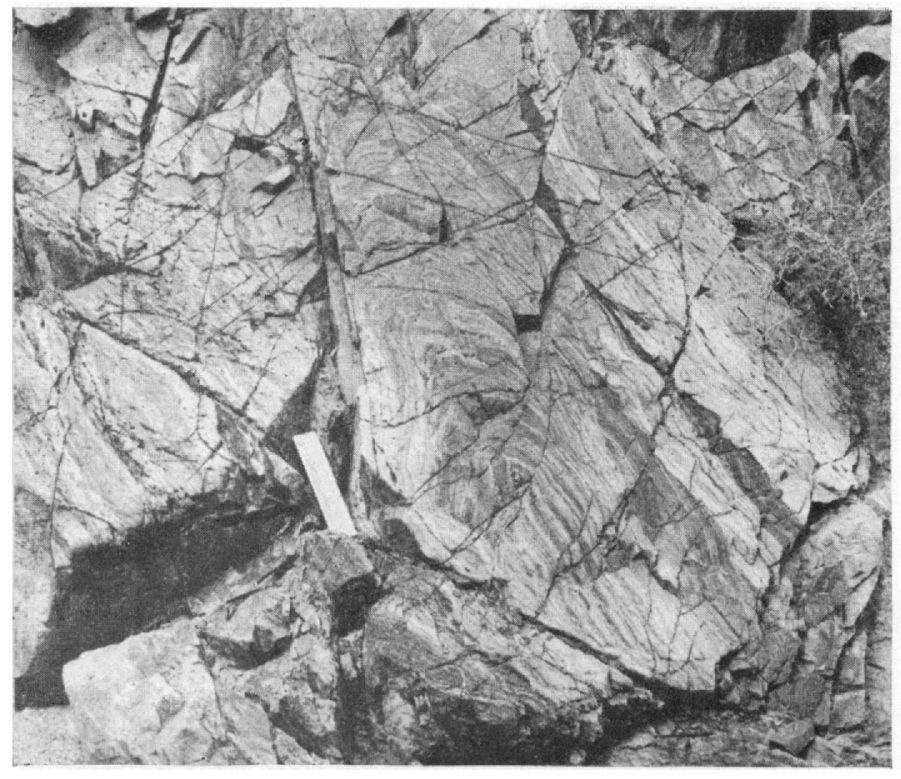

1, INTHECTLA CONTORTED SAVBSTONE OF DENLAT FOR MATION BLLOW SIPAHAINT JHRLST, MAC CANYON, PILOT MOUNTAINS.

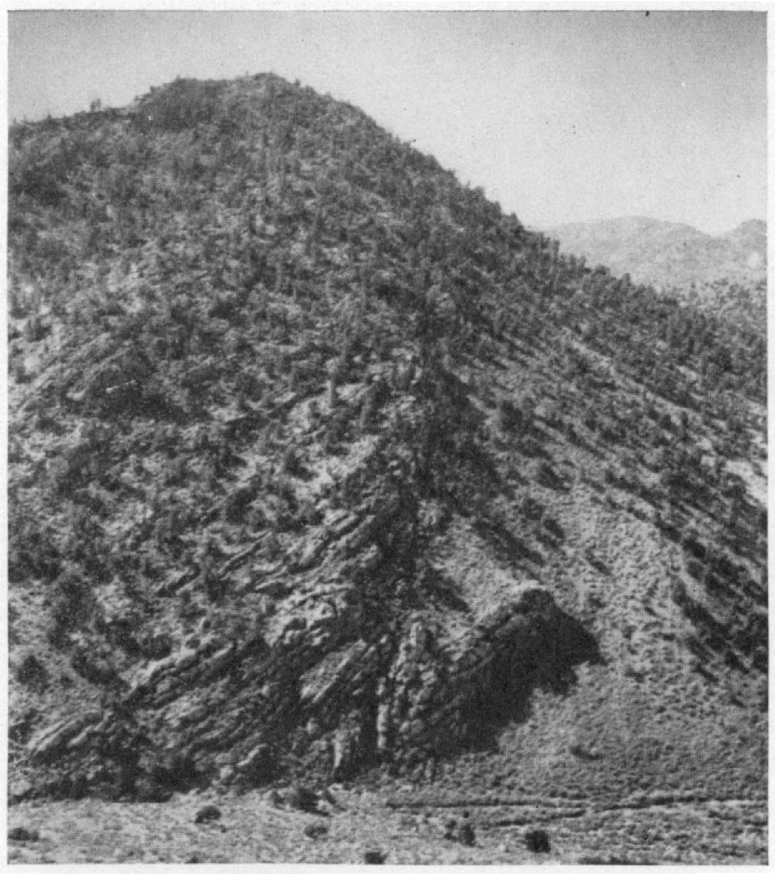

C. SHOSHONE THIHLST.

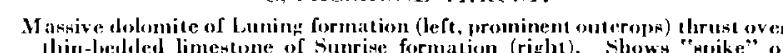
dolomite alon: thrust plane. South wall of Milton Canyon, shoshone Moutlitins.

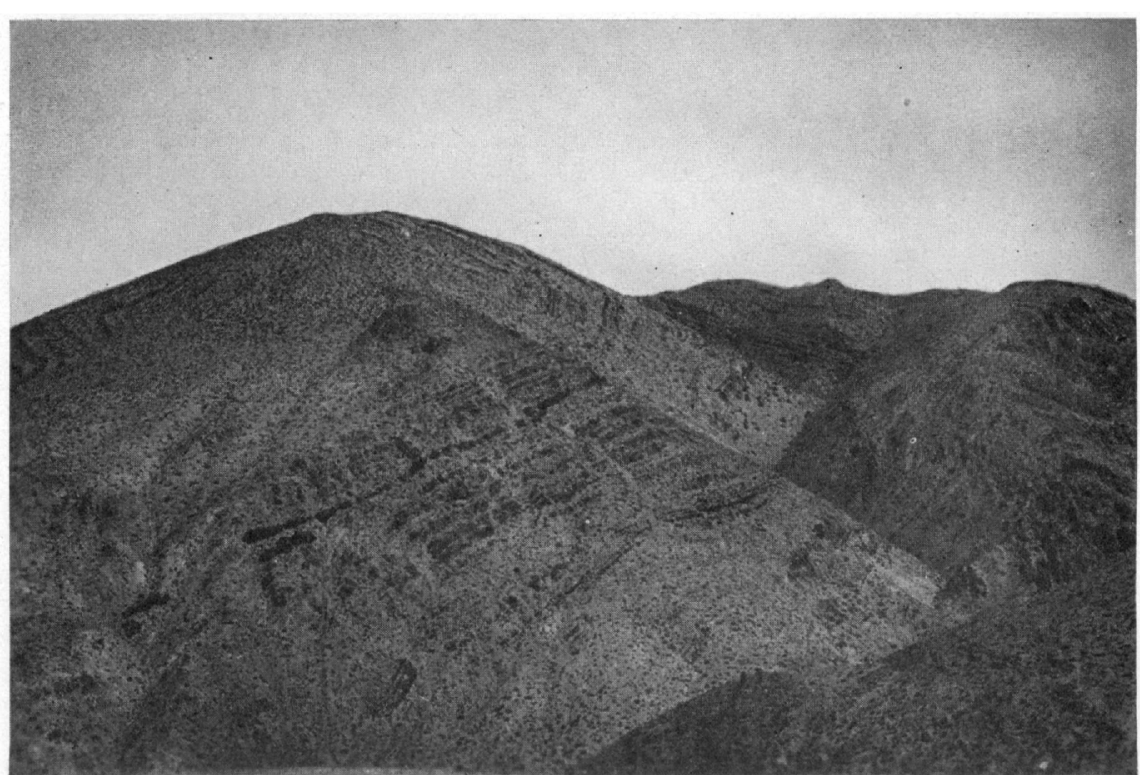

H, NOR'TI OF MAC CANYON, PILOT MOL X'TAINS, SHOWINE: IN VOLU'TE FOID. Overturned slate unember of Luning formation above upper limestone, at left.

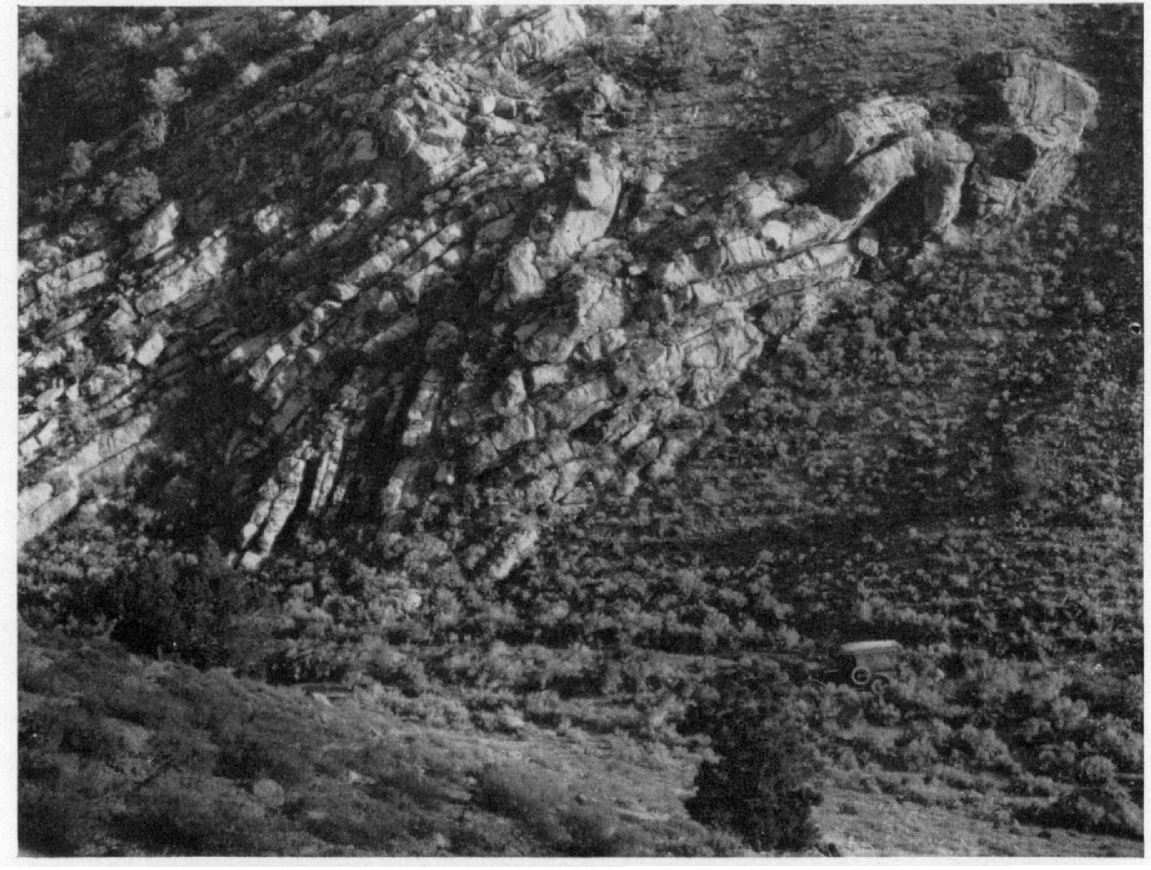

D, SIIOSIIONE TILUST. Nearer view of "syike" of alchomite of Luning formation on thrust pline. Truck in canyon helow spike pives 

per and lower plates, suggests that total movement was much greater and it is possible that this is one of the major thrusts of the area.

The conglomerate in the Dunlap formation at the south end of the mapped area contains dolomite pebbles suggesting that the thrust may here have moved over an erosion surface; but there are no thrust conglomerates along the thrust plane itself.

Later faulting.-Reverse faulting along Grantsville Canyon (pl. 13) brings the lower plate of the Shoshone thrust against the upper. Total displacement must be of the order of thousands of feet, principally concentrated along the southermmost of the group of steeply dipping faults.

The gently folded pre-Tertiary rocks north of Grantsville Canyon are cut by many normal faults of varying strike and displacement. The two principal faults, the Union Canyon and Richmond Hill faults, bound Richmond Hill on the north and west (sec. $C-C^{\prime}$, pl. 12), and a group of smaller faults branch out fanwise from the junction of these two. Other faults that crop out in the pediment west of Richmond Hill are parallel to the Richmond Hill fault, and smaller faults striking west and southwest cross the summit of Richmond Hill.

The Richmond Hill fault (pl. 13) borders the Permian (?) on the west. Just south of Union Canyon it dips about $30^{\circ} \mathrm{W}$., steepening to $60^{\circ}$ midway between Grantsville and Union Canyons. The throw is only approximately measurable; but, assuming that the fault breaks an anticline whose eastern limb is formed by the Grantsville and Luning formations on Richmond Hill, the vertical displacement is about 1,500 feet. If the faulted segment of Luning on the west front, north of Grantsville Canyon, marks the southern extension of the Richmond Hill fault, movement was later than the reverse faulting along Grantsville Canyon.

Several small faults striking west and northwest displace the contact between Luning and Grantsville along the crest of Richmond Hill. With two exceptions, the downthrow is to the north and northeast. The largest fault has a vertical displacement of about 400 feet, and the aggregate displacement of the entire group is not more than 600 feet. The presence of a small fault following the valley east of Richmond Hill is suggested by the discordance of attitude of the limestone and slate units of the Luning.

The Union Canyon fault crops out along the southern fork of Union Canyon from the lava covered area on the east to the junction with the Richmond Hill fault near the forks of Union Canyon. The dip is steep, apparently generally northerly; though it may be southerly for a short distance east of the forks of Union Canyon. At one place along the plane of this fault is a small aplite dike. Northwest of the forks of the canyon, the Union Canyon fault has a northwesterly strike and a vertical to steep southwesterly dip and separates the area of homoclinal easterly dip on the north from the broad syncline of the downthrown block of the Richmond Hill fault on the south.

Westward from the forks of Union Canyon and extending into the Permian (?) near Berlin (pl. 13), a group of diverging faults strike between northwest and west. The apparent downthrow is mainly to the west and south (sec. $B-B^{\prime}$, pl. 12), though in places minor wedges are displaced in opposite directions. The aggregate downthrow to the southwest probably does not exceed 500 feet.

The observed relations of the different normal faults are best explained by assuming that earlier horizontal movement on the Union Canyon fault shifted the northern block containing the northern segment of the Shoshone thrust, about a mile relatively westward. The homoclinal easterly dips north of the eastern part of the Union Canyon fault (sec. $A-A^{\prime}$, pl. 12) are accordant with the structure on Richmond Hill, but not with the syncline immediately to the south. The presence of aplite along the plane of the Union Canyon fault but not along others suggests that it may be older. This horizontal movement may have been followed by relative uplift of the block bounded by the Richmond Hill fault and the eastern segment of the Union Canyon fault. The faults fanning out from the intersection of the two major faults may represent adjustment in the downthrown block at the point of major stress, and the small transverse faults on Richmond Hill the adjustment to the uplift in the southern part of the upthrown block. The parallel faults west of the Richmond Hill fault may be subsidiary to the Richmond Hill fault, and the gentle syncline to the west in part, perhaps, the result of compression of the downthrown bloek.

Possible confirmation of later normal faulting in two directions is the post-mineralization faulting in the nearby Berlin mine described by Daggett. ${ }^{28}$ The vein, which crops out at the front of the range, belongs to the period of mineralization associated with the intrusion of the granodiorite and aplite. It strikes northeast, dips $45^{\circ} \mathrm{SE}$., and is cut by two systems of faultsone striking north and dipping $40^{\circ} \mathrm{W}$., the other striking N. $59^{\circ} \mathrm{W}$., and dipping about $63^{\circ}$ NE. Faulting along these two systems must have been contemporaneous because fanlts of each system displace those of the other. The net morement in the part of the mine dereloped at that time was calculated by Daggett to be 420 feet on a pitch of $33^{\circ} \mathrm{NW}$., or a net vertical displacement of 220 feet.

The small dike of aplite along the Union Canyon fault is indicative that at least the earlier horizontal movement took place during the Jurassic diastrophism

ss Daggett, Elsworth, The extraordinary faulting at the Berlin mine, Nev. : Am. Inst. Min. Met. Eng. Trans., vol. 38, pp. 297-300, 1908. 
prior to the granitic intrusion and consequently may be associated with the westward movement along the Shoshone thrust. The Union Canyon fault does not displace the Tertiary rhyolite in the eastern part of Union Canyon. The later vertical movement on this fault and presumably also the development of the Richmond Hill fault was, therefore, if not pre-Tertiary, at least older than the rhyolite which is believed to be Upper Miocene.

Movement along parts of these faults may have been renewed during the later basin-range faulting. The range is a fault block tilted gently eastward. For the most part, the scarp is not distinct, but the west face of Grantsville Ridge shows well-preserved facets and at one locality a 10-foot scarp at the base of the ridge preserves fault striae. The Richmond Hill fault and the minor faults to the west are parallel to the range front. Difference in altitude of the Tertiary lava on the pediment west of Richmond Hill and that on the east flank of the hill is not definite evidence of faulting because the lavas were probably poured out on an irregular surface. A few northerly faults, however, involve the Tertiary lavas; and it is possible that there was late Tertiary or Quaternary movement also on the Richmond Hill fault.

\section{EXCELSIOR MOUNTAINS}

The Excelsior Mountains (pls. 1, 2,14), in contrast to the trend of the neighboring ranges, extend in a nearly easterly direction across the southeastern part of the Hawthorne quadrangle, from the south end of the Wassizk Range to the southern part of Soda Spring Valley opposite the Pilot Mountains. The topographic relief in large part is due to Tertiary and Quaternary faulting, and the range appears to be a complex fault block tilted to the north; consequently, over most of its length, Tertiary lava flanks the north slopes and covers part of the crest, and the older rocks crop out along the south front. The only portion examined in detail was a small area in the eastern part of the range that was mapped in connection with the study of the mines of the Gold Range mining district (pl.14). Elsewhere the geology is known only from reconnaissance.

\section{ROCKS EXPOSED}

The exposed pre-Tertiary rocks include the Excelsior formation, the Dunlap formation, and granitic instrusives.

Excelsior formation.-Chert, siliceous tuff, and lesser amounts of greenstone and felsite compose the larger part of the Excelsior formation. In the Gold Range mining district at the east end of the range (pl. 14), the upper part of the formation consists of felsite and felsitic agglomerate generally less than 1,000 feet thick but reaching a maximum of more than 2,000 feet. The felsite is overlain unconformably by the Dunlap formation. Below the felsite is a much greater thickness of chert interbedded with dark siliceous tuff and minor amounts of sandstone and conglomerate. In the eastern part of the district there are flows of greenstone in the upper part of the chert member.

Dunlap formation.-The Dunlap formation overlies the Excelsior in the Gold Range district, in the central part of the range, north of Marietta, on the crest of the ridge between Huntoon Valley and Teels Marsh, and west of Huntoon Valley (pl. 1).

At the base of the Dunlap in the Gold Range district (pl. 14) is a breccia consisting of angular fragments derived from the underlying felsite flows in the Excelsior. The breccia is not present everywhere, and its greatest thickness does not exceed 250 feet. The deposit, which is composed of unsorted material and lacks distinct bedding, resembles a talus breccia rather than the fanglomerate that is present elsewhere in the Dunlap. Near the top, however, the pebbles in part are rounded, and faint bedding is observable. Above the breccia is conglomerate, which for about 100 feet above the base is composed of felsite pebbles but in the upper part, entirely of chert. No limestone or dolomite pebbles are present. The upper part of the formation consists of interbedded red sandstone and conglomerate, a little red sandy shale, and one thin lens of marine limestone.

In the large area north of Marietta (pl. 1), the formation is similar to the Dunlap of the southern Garfield Hills. Sandstone and conglomerate in the lower part of the formation are overlain by several hundred feet of greenstone and greenstone breccia, interbedded with a little sandstone. The sedimentary member has a much greater surficial extent on the northwest than on the southeast flank of the syncline, but the structure is insufficiently known to determine whether this is due to thickening toward the northwest or to the attitude of the beds.

The Dunlap in the small areas on the ridges bordering Huntoon Valley (pl. 1) consists of conglomerate, red sandstone, and minor amounts of shales and marine limestone.

Intrusive rocks.-The rock on the western part of the range, except the ridges bordering Huntoon Valley, is very coarse-grained granodiorite identical in appearance with that of the Wassuk Range to the West. Essentially continuous outcrop of granitic rocks connects this granitic area with the Sierra batholith to the west. Many small masses of granitic and porphyritic rocks including diorite, quartz monzonite, granite, and granite porphyry, cut the Excelsior in the eastern part of the range.

\section{STRUCTURE}

It is unknown to what extent the Excelsior was folded prior to Dunlap deposition. Folding in the Dunlap generally trends northeastward, swinging eastward in 
the eastern part of the range. The steeper dips seem to be on the southeast limbs of the synclines, contrary to the prevailing assymmetry of the folds in the Garfield Hills and Pilot mountains to the north. The position of the various granitic rocks appears to lack direct structural significance, but there is a marked parallelism of the Tertiary and later faults with the prevailing trends of the Jurassic folding.

Pre-Jurassic folding.-The Dunlap is unconformable on the Excelsior, but no definite information on the amount of angular discordance was obtained. In the Gold Range district, local topographic irregularity is suggested by the talus-like breccia at the base of the Dunlap, and angular unconformity by the chert pebbles in the conglomerate; but in the area studied in detail (pl. 14) the contact of Dunlap and underlying felsite of the Excelsior is roughly parallel to that of the felsite and greenstone within the Excelsior. Certainly there is no sharp angular unconformity such as was observed in the Pilot Mountains. The Dunlap west of Huntoon Valley appears to lie on the truncated folds of the Excelsior, but this was not definitely proved.

Jurassic folding.-The synclines that enclose the different areas of Dunlap vary in trend. The westernmost two, bordering Huntoon Valley (pl. 1), and the large syncline in the central part of the range, trend northeast and dip most steeply on their southeast limbs; but, northwest of Marietta and north of the crest of the range, the conglomerate dips prevailingly to the east. Southwest of Garfield Flat the contact of Dunlap and Excelsior formations trends nearly east, and the Dunlap dips steeply southward. The small syncline in the Gold Range mining district, at the eastern end of the mountains appears to trend east or northeast.

Later faulting.-The trends of the later faults follow approximately those of the older structure. In the Gold Range district (pl. 14) two late Tertiary faults are the loci of veins carrying ores of gold and tungsten. On the northern fault, displacement of the earlier structure suggests a considerable horizontal component. There are faults of northeasterly trend along the eastern end of the range, opposite Rhodes Salt Marsh (pl. 1). The south front of the range north of Marietta is a fault scarp; and a westward-striking fault, which has late Tertiary andesite on its southern wall, crosses the southeast corner of the range between Teels Marsh and Rhodes Marsh. The two southeast spurs flanking Huntoon Valley are bordered by northeastward-striking faults, which have displaced Pleistocene basalt and gravels. The basalt flows south of Huntoon Valley are cut by many northeastward-striking faults.

During the earthquake of January 30, 1934, a scarp with a maximum height of 5 inches was formed along an old northeasterly fault within the Excelsior on the south flank of the range. ${ }^{29}$ This fault does not reach the contact with the Tertiary lava and prior to the earthquake showed no topographic evidence of recent movement.

\section{MILLER MOUNTAIN AND CANDELARIA HILLS}

Several areas in the hills in the southeastern part of the Hawthorne quadrangle are underlain by pre-Tertiary rocks. These outcrops extend from Miller Mountain northward to the belt of Tertiary and Quaternary lavas south of Excelsior Mountain, and a short distance into the Tonopah quadrangle (pl. 1). Cambrian and Ordovician rocks underlie the larger part of the exposed areas of pre-Tertiary rocks. North of the Ordovician is a narrow belt of Permian, overlain by the Lower Triassic Candelaria formation. In the northeastern part of the area, principally within the Tonopah quadrangle, Permian conglomerate rests on the Ordovician in one plate of the Monte Cristo thrust, and volcanic rocks assigned to the Excelsior formation overlie the Ordovician in the other plate (figs. 9, 10).

\section{ROCKS EXPOSED}

Cambrian sedimentary rocks.-The Cambrian, which is several hundred feet thick, crops out only on the south flank of Miller Mountain, near the southern border of the quadrangle. The rocks are largely slate and schist but contain a little quartzite and conglomerate and, near the top of the section, a bed of dolomitic limestone.

Ordovician sedimentary rocks.-Ordovician rocks underlie large areas on the north flank of Miller Mountain, in the low hills west of the highway, and in the hills south and southeast of Candelaria. The thickness is undetermined but may exceed 4,000 feet. The lower part consists largely of black limestone, irregularly silicified and interbedded with dark slate; the upper part contains relatively little limestone and consists principally of black chert and dark siliceous slate.

Permian sedimentary rocks.-Permian rocks rest on the Ordovician with angular unconformity and are overlain by the Lower Triassic Candelaria formation with marked erosional but not noticeable angular unconformity. In contrast to the great thickness in the Toyabe Range, the Permian of the Candelaria region probably nowhere exceeds 400 feet and averages much less than 100 feet. In places it is missing entirely, and the Candelaria formation rests on the folded Ordovician. Over most of the area the Permian consists of sandstone and coarse grit, composed largely of quartz and dark chert fragments derived from the underlying Ordovician. In some localities the arenaceous rock grades into a brown dolomite, which locally constitutes the entire thickness of the formation (fig. 8). Still

\footnotetext{
${ }^{29}$ Callaghan, Eugene, and Gianella, V. P., The earthquake of Jan. 30, 1934, at Excelsior Mountains, Nevada: Seismol. Soc. Am. Bull., vol. 25, pp. 161-168, 19:35.
} 

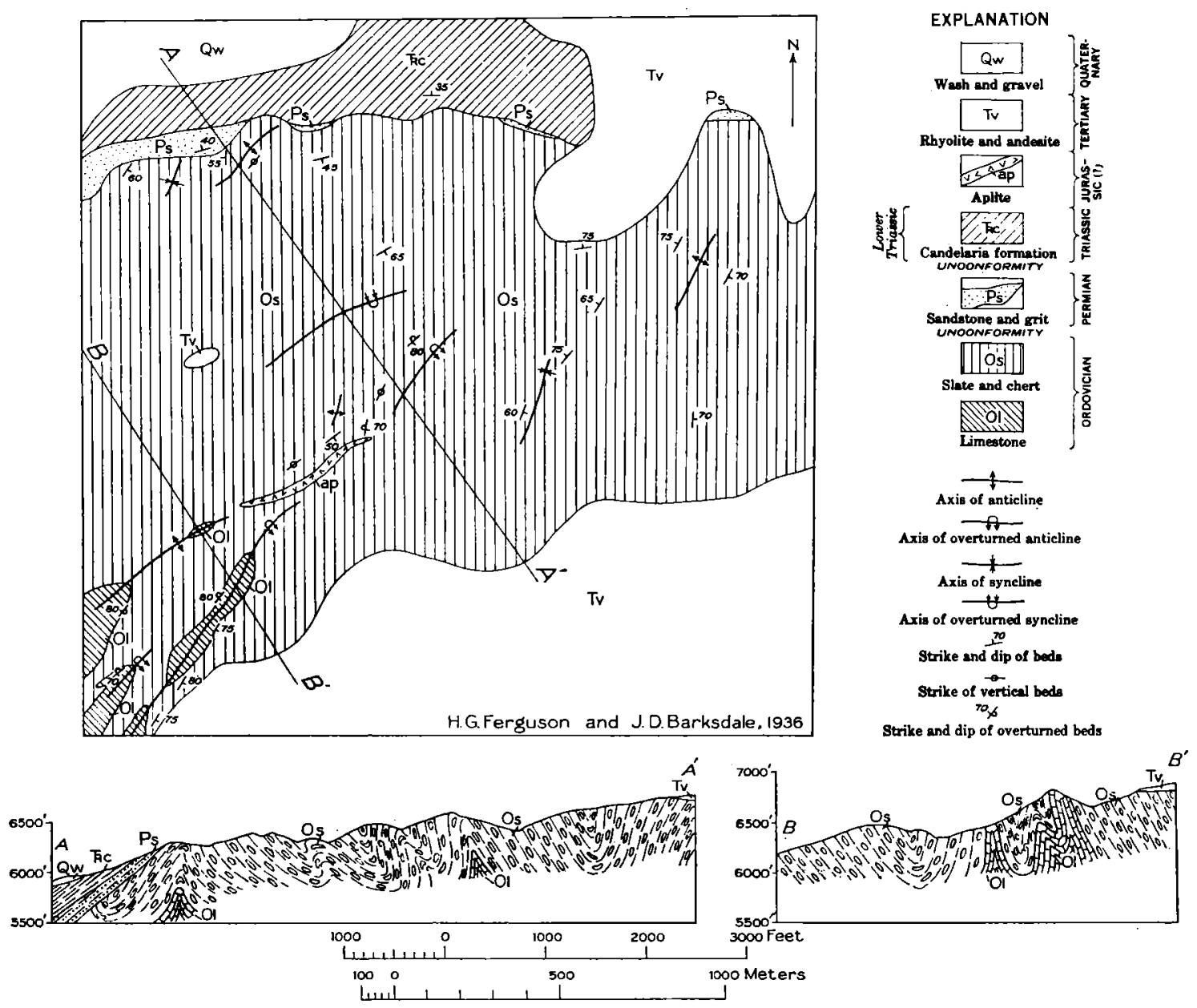

Figure 7.-Geologic map and sections of area west of Candelaria, showing relation of Lower Triassic Candelaria formation and Permian sandstone to the folded Ordovician.

farther east, but isolated from the other Permian areas, a small hill east of the railroad at the north end of Columbus Salt Marsh consists of conglomerate and fanglomerate containing fragments of Ordovician chert. A similar conglomerate overlies the Ordovician west of the railroad near Redlich siding (fig. 9).

Candelaria formation.- The Lower Triassic Candelaria formation (fig. 8), which borders the Permian on the north, consists of about 3,000 feet of thin-bedded shales and conglomerate containing pebbles of Ordovician chert. The conglomerate occurs, for the most part, several hundred feet above the base, in the eastern part of the area. The basal conglomerate is inconspicuous, rarely over a foot or two thick, and is missing in places. Lenses of fossiliferous calcareous shales are present within this lowermost 200 feet of the formation.

Excelsior (?) formation.-In the northeastern part of the Candelaria Hills, volcanic rocks, believed to be the basal part of the Excelsior formation, also rest on the Ordovician with marked angular unconformity (fig. 9). These consist of an agglomerate composed of fragments of vesicular greenstone. Rarely, thin flows and dikes of a similar rock are encountered. Greenstone dikes also cut the Ordovician. A few thin beds of tuffaceous sandstone are the only sedimentary rocks. More massive greenstone, similar to that in the Excelsior Mountains, crops out in isolated areas between the Candelaria Hills and the Excelsior Mountains. This volcanic rock was not found in contact with the Candelaria formation or with the Permian, and it is beliered that a major thrust separates two widely different facies; in one Ordovician is overlain by the Permian and the Lower Triassic Candelaria formation while in the other the Ordovician is overlain by the volcanic rocks of the Excelsior formation.

Intrusive rocks.-Small masses of granodiorite intrude the Cambrian on the southeast spur of Miller Mountain and the Ordovician west of Columbus, and diorite cuts the Ordovician east of Candelaria. Sills and dikes of fine-grained aplite are abundant in the thin-bedded Candelaria formation. Serpentine dikes, not found elsewhere in the region, are common in the Candelaria formation, particularly in the vicinity of Candelaria. Masses of secondary dolomite associated 


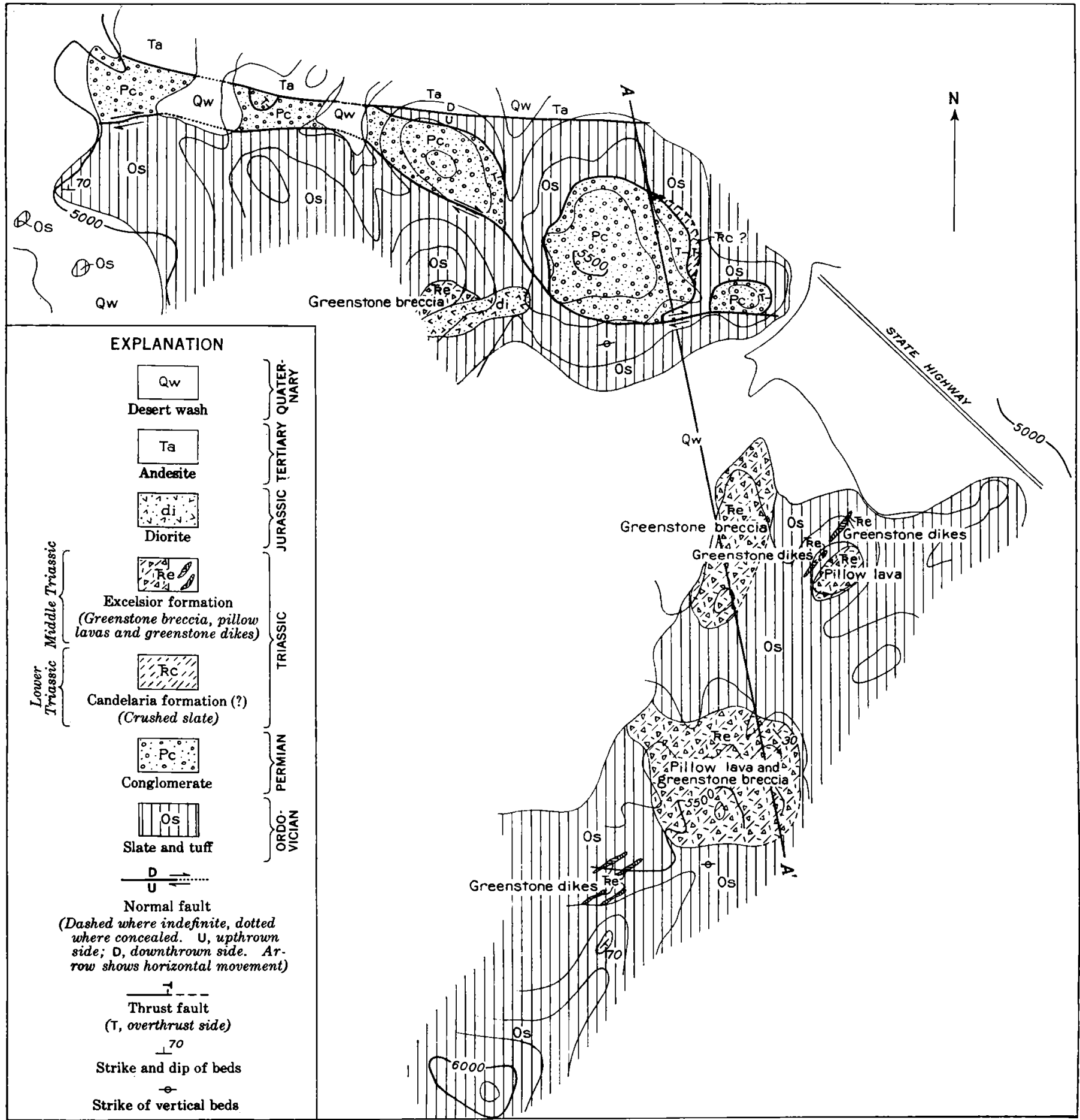

H.G. Ferguson and S.W. Muller, 1937

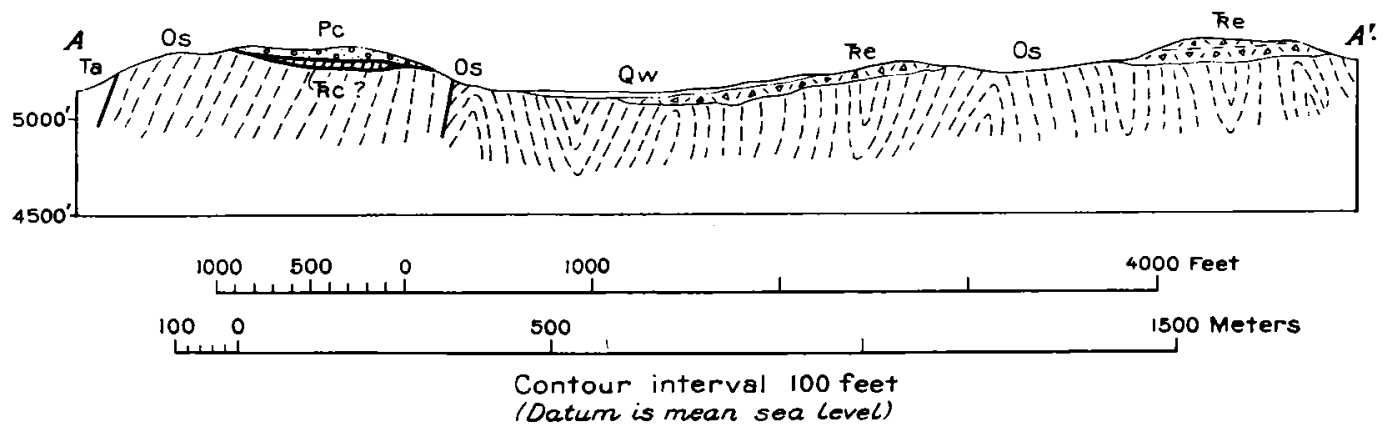

Figdre 9.-Geologic map and section of area south of Redlich siding, showing relations of the Ordovieian and Permian and the Excelsior formation. 
with several of the serpentine dikes replace the márginal portions of the dikes and the adjoining shale and sandstone of the Candelaria formation.

\section{STRUCTURE}

At least two periods of folding are represented, the earliest prior to the Permian. Later than the Excelsior formation the northern part of the area was broken by a major thrust, probably the same as the Monte Cristo thrust (p. 48). Ordovician, overlain by Permian sedimentary rocks and the Candelaria formation, was thrust over Ordovician upon which volcanic rocks, believed to be the basal part of the Excelsior formation, rest unconformably. Two faults, one perhaps allied to the flaw in Soda Spring Valley and the other a displacement of late Tertiary age, cut this thrust.

Pre-Permian folding.-The structure of the prePermian rocks was not worked out in detail except close to the contact of the younger rocks, but reconnaissance of Miller Mountain indicates rather gentle folds of prevailing easterly trend. In the small exposures of Ordovician west of Miller Mountain the trend is northeasterly.
In the western part of the Candelaria Hills (fig. 7) the folds in the Ordovician trend and pitch to the northeast and in part are overturned to the northwest. The northeasterly trend continues as far east as Candelaria, so that exposed contacts show striking angular unconformity of the northward-dipping Permian above the Ordovician. Eastward from Candelaria (fig. 8) the Ordovician strikes prevailingly westward, parallel with the overlying Permian and Candelaria formations, but generally dips more steeply.

Monte Cristo thrust.-The thrust plane that separates the Ordovician overlain by the volcanics of the Excelsior formation from the Ordovician overlain by the Permian and the Candelaria formation crops out only at two localities. On the eastern front of the range, 5 miles south of Redlich, highly folded slates and cherts of the Ordovician are thrust over greenstone breccia, which forms small outcrops at the edge of the valley. The underlying Ordovician of the lower plate is not exposed. The dip of the thrust plane appears to be to the west, and the dragfolds in the Ordovician indicate eastward movement of the upper plate.

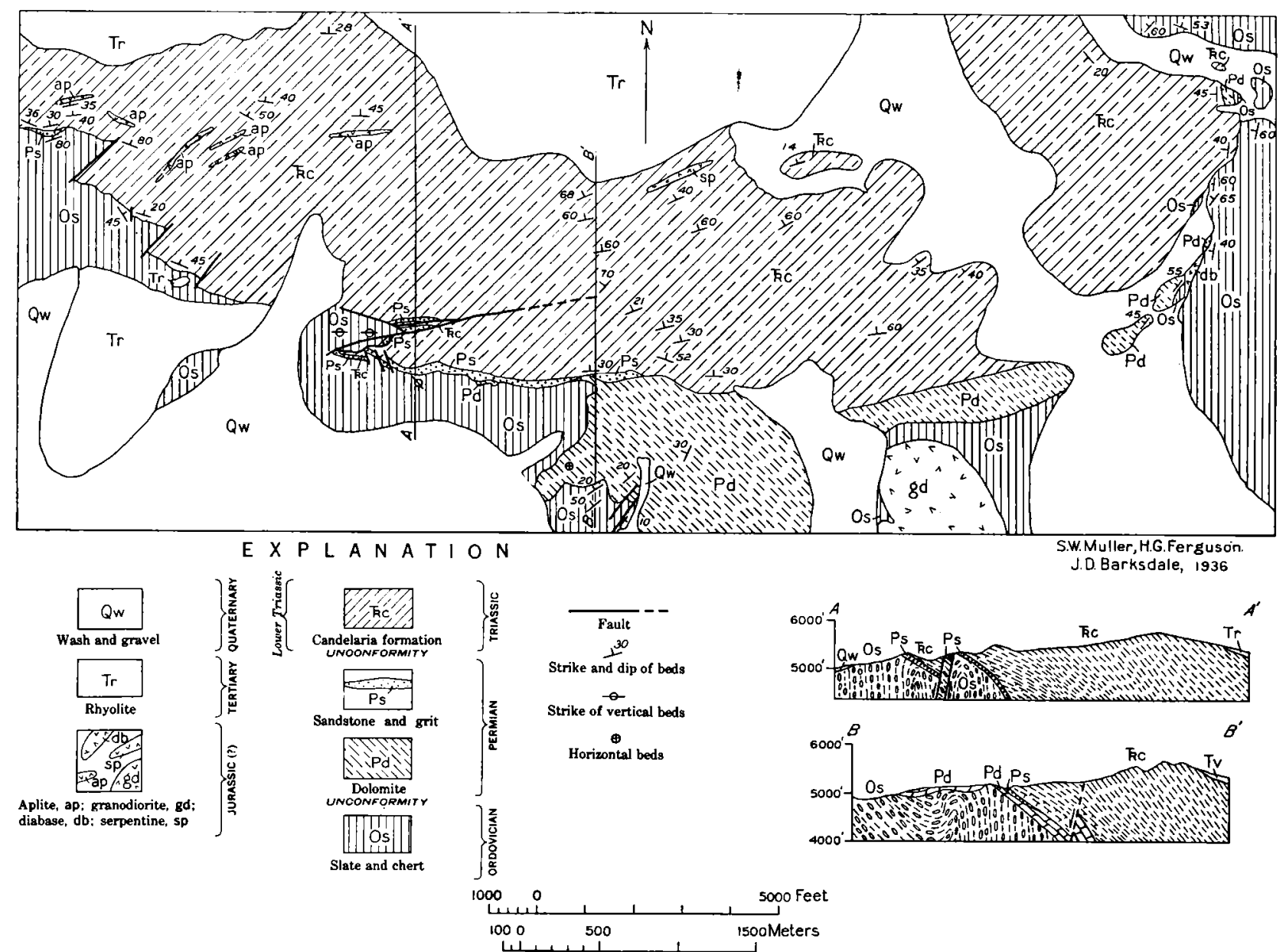

Figure 8.-Geologic map and section area east of Candelaria, showing principal section of the Candelariz formation and its relation to the underlying rocks. 
At the northeastem corner of the range, 2 to 3 miles south of Redlich siding, massive Permian conglomerate is thrust over Ordovician rocks. The thrust crops out for a little more than a mile along the north front of a small ridge and appears to dip gently to the west. At one point a sliver of highly crushed slate, containing concretions like those found elsewhere in the Candelaria formation, lies between the Permian and the Ordovician and may indicate that the thrusting here was more complex than in the area to the south (fig. 9).

Later fautting.-On the south side of the small ridge capped by the Permian the thrust is cut by a fault striking west-northwest and dipping from $60^{\circ} \mathrm{N}$. to $80^{\circ}$ S. South of this fault the Ordovician is overlain unconformably by greenstone breccia and greenstone, in part showing pillow structure, and is cut by many dikes of greenstone. The greenstone breccia is similar to that exposed to the south, below the thrust and also in the lower plate of the thrust in the Monte Cristo Range.

The displacement of the fault cannot be determined, but its strike, varying dip, and relation to the thrust suggest that movement may have been largely horizontal and perhaps was associated with that along the major flaw in Soda Spring Valley.

The Monte Cristo thrust in the area south of Redlich is cut off by a westward-striking fault, which has late Tertiary andesite on the downthrown side (fig. 9).

Normal faults striking northeastward and eastward cut the older rocks east of Candelaria (fig. 8) and are believed to be of Tertiary or Quaternary age; faults following the same trends displace the later lavas near Candelaria.

\section{MONTE CRISTO RANGE}

The surface of the Monte Cristo Range is largely covered by Tertiary and Pleistocene formations. PreTertiary rocks crop out only in relatively small areas the largest of which, in the southwestern part of the range, reveals the Monte Cristo thrust (fig. 10). The structural relations of the pre-Tertiary rocks in the smaller areas are unknown.

\section{ROCKS EXPOSED}

Ordovician chert and slate, similar to the rocks in the upper part of the Ordovician in the Candelaria Hills, crop out in the upper plate of the Monte Cristo thrust and in the small pre-Tertiary exposures in the eastern and central parts of the range. Permian sediments, consisting of variable amounts of basal conglomerate orerlain by dolomite, are unconformable on the Ordovician in the southwestern part of the range. In the same area greenstone breccia of the Excelsior formation, similar to that which overlies the Ordovician in the northeastern part of the Candelaria Hills crops out in the lower plate of the Monte Cristo thrust. In the extreme northeastern part of the range interbedded chert and tuff are lithologically similar to the Excelsior formation in the southern parts of the Pilot and Cedar Mountains.

\section{MONTE CRISTO THRUST}

The only area of the range studied in detail is that on the southwestern slope where the Monte Cristo thrust is exposed (fig. 10). The upper plate of this thrust consists of folded Ordovician chert and slate upon which the Permian sediments rest with marked angular unconformity. In general the folds in the Ordovician seem to trend west and northwest, but lack of key beds prevented determination of the structure. The more gently folded Permian seems to lie in a superposed syncline of northwesterly trend. The structure of the lower plate could not be deciphered because bedding in the greenstone breccia is almost completely lacking.

It is assumed, from the similarity of the formations on both plates, that the Monte Cristo thrust also outcrops in the northeastern part of the Candelaria Hills 6 miles to the northwest (fig. 9). Assuming the movement was eastward, the minimum displacement may have been 8 or 10 miles; but the fact that rocks of entirely different character and age overlie the Ordovician on the upper and lower plates suggests much greater displacement.

\section{LONE MOUNTAIN}

In Lone Mountain (pl. 1) Cambrian rocks consisting of quartzose chloritic schist and dolomitic limestone are intruded by porphyritic granite and subordinate masses of aplitic granite and diorite. The contact of intrusive and sedimentary rocks is highly irregular in detail, but on the northeast side of the principal igneous mass the Cambrian rocks dip northeast, and on the southwest side they dip southwest.

According to Ball ${ }^{30}$ the general trend of the major folds in the southern part of the range, a few miles south of the edge of the Tonopah quadrangle, is east of north, and that of the minor folds due east. The folding is most intense in the northern part of the area covered by Ball's map, just south of the Tonopah quadrangle.

No thrust faulting was observed in the area studied, and none was noted by Ball in the area to the south though he notes that "fanfolds and isoclinals are common." 31

\section{SAN ANTONIO MOUNTAINS}

The San Antonio Mountains, in the southeastern part of the Tonopah quadrangle, are largely covered by Tertiary rocks, and the older rocks are exposed in only a few small areas. In the eastern part of the range, rocks of probable Ordovician age dip northeast. In the

\footnotetext{
${ }^{30}$ Ball, S. H., A geologic reconnaissance in southwestern Nevada and eastern California: U. S. Geol. Survey Bull. 308, p. 54, 1907.

${ }^{31}$ Ball, S. H., op. cit., p. 54.
} 


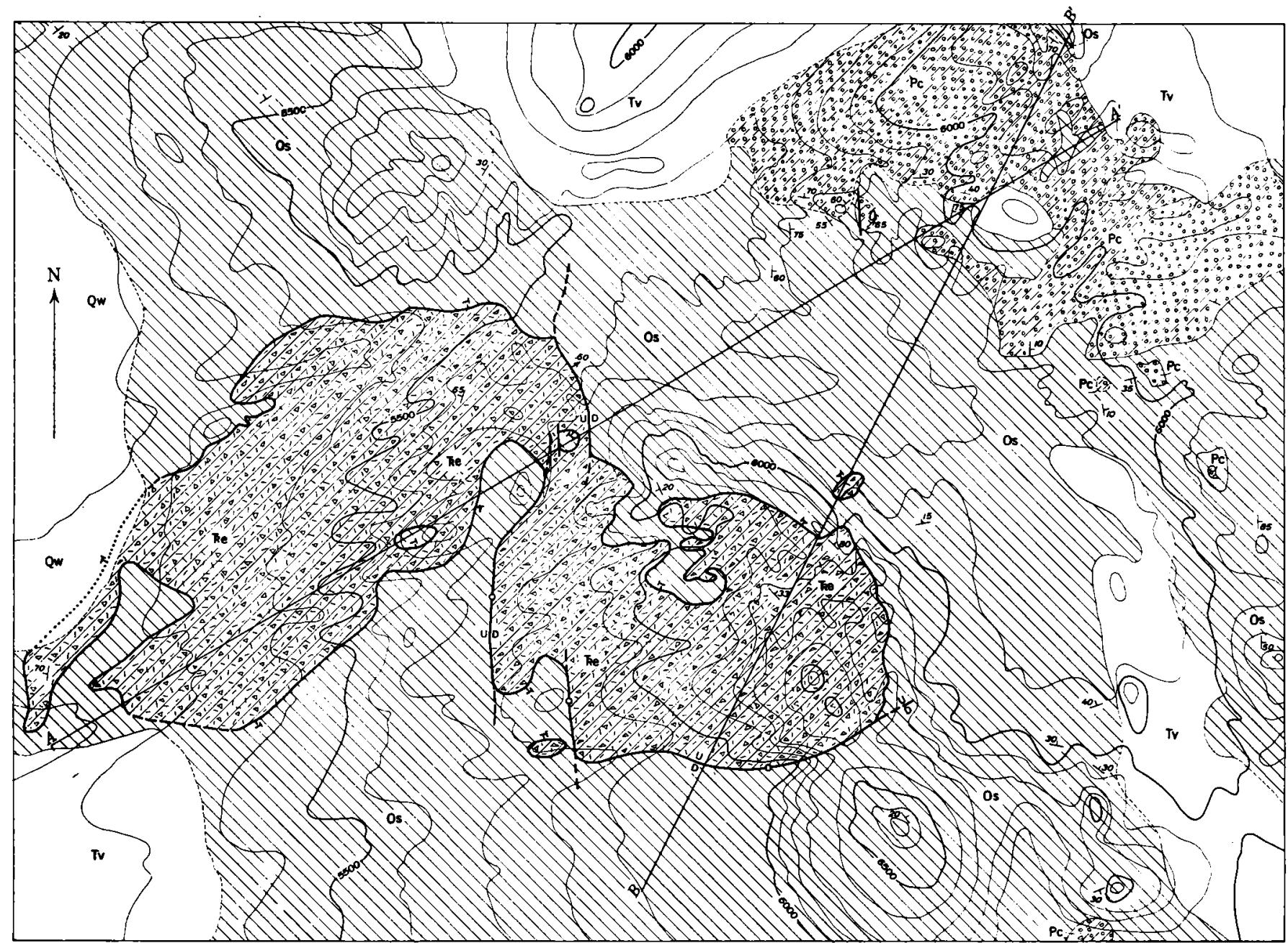

H. G. Ferguson, S.W. Muller, and A.E.Granger, 1938

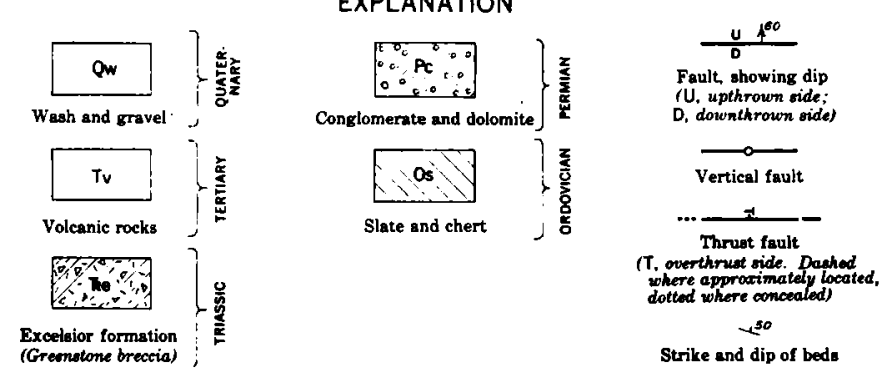

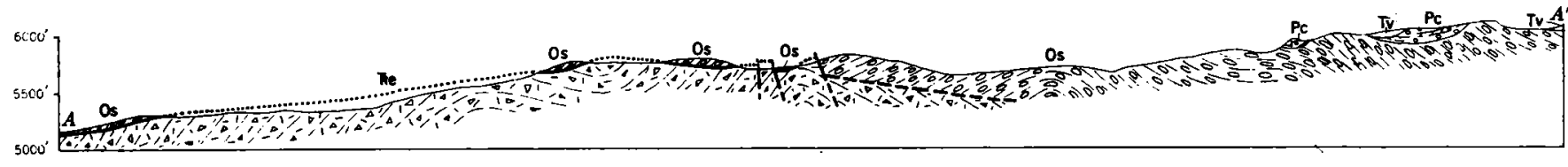

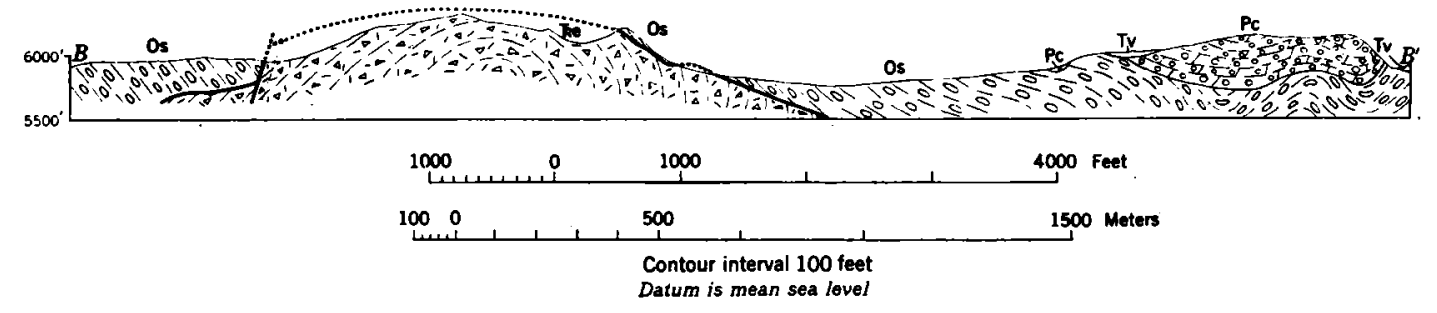

Figore 10.-Geologic map and sections of a part of the Mon te Cristo Range, showing outcrop of the Mfonte Cristo thrust. 
central part a few miles north of Tonopah, a larger area of pre-Tertiary rocks includes the only Deronian known in the two quadrangles. The Devonian overlies the Ordovician with only minor angular discordance and consists of about 400 feet of gray limestone, fossiliferous near the base. North of the outcrop of the limestone, a little black fissile slate, of unknown age, appears to be faulted against the Devonian or may be overthrust by the Devonian. The Devonian limestone occupies a gentle syncline, which trends a few degrees west of north. To the south the Ordorician chert and slate contain only minor amounts of limestone and are lithologically similar to the rocks in the upper part of the section in the Toquima Range. Porphyritic granodiorite intrudes the Ordovician strata. On the east the Ordovician and Devonian are faulted against the Tertiary lava and sedimentary rocks, and near the fault the Devonian limestone is highly silicified.

The pre-Tertiary rocks exposed at the northwest end of the range are probably of Permian age and consist of interbedded chert, tuff, breccia, greenstone, and in places a little limestone. They are in general lithologically similar to the dominantly volcanic upper part of the Permian in the Toyabe Range. The dips are sieep and the strikes predominantly westerly. The major structure is possibly a westward-trending syncline upon which minor folds are superposed. The preTertiary rocks are cut by granitic and aplitic intrusions and by irregular masses of rhyolite porphyry, which is probably of late Tertiary age. Tertiary lava, also cut by intrusive rhyolite, overlies the older rocks irregularly, suggesting a very uneven pre-lava topography.

At the eastern border of the Permian is a reverse fault along which the Permian, the overlying flows. and the rhyolite porphyry are thrust against Tertiary lava. The fault is traceable for about 2 miles. At its northern end it is overlapped by lava younger than the intrusive rhyolite, at its southern end it is not definitely traceable far beyond the contact with the intrusive rhyolite and the surrounding rocks. The fault dips eastward from about $60^{\circ}$ to practically vertical.

Other Tertiary faults appear to be normal and, for the most part, strike northward following the trend of the range. The range front itself does not appear to be a fault scarp except, possibly, for a short distance along the west border at its northern end. The highly complex Tertiary faulting in the Tonopah district has been described by Nolan. ${ }^{32}$

32 Nolan, T. B., The underground geology of the western part of the Tonopah mining district, Nevada: Nevada Univ. Bull., vol. 24, no. 4, 1930 ; Underground geology of the Tonopah mining district, Nevada: Nevada Univ. Bull., vol. 29 , no. 5. 1935.

\section{TOQUIMA RANGE}

The southwestern part of the Toquima range (pl. 1) within the Tonopah quadrangle contains two areas of pre-Tertiary rocks: a northern consisting largely of granodiorite and granite fringed by metamorphosed Ordovician schist and limestone along its northern and southwestern borders, and a southern containing Cambrian and Ordovician sediments intruded by porphyritic granodiorite. The northern part of the southern area was mapped in connection with the study of the Manhattan mining district. ${ }^{33}$

\section{ROCKS EXPOSED}

The Cambrian consists of schistose slate, quartzite, sandstone, and a few beds of white crystalline limestone. The total exposed thickness is nearly 5,000 feet. The Ordovician is about 5,600 feet thick and, except for about 800 feet of dark limestone in the lower part, consists essentially of chloritic schist, quartzite, slate, and thin beds of dark limestone.

The Ordovician of this area and that exposed at Belmont, 15 miles to the northeast, is near the eastern limit in this latitude of the prevailingly slatey facies of the Ordovician of the western part of the Great Basin. In the same range in the southwestern part of the Roberts Mountain quadrangle, about 30 miles north of Manhattan, and at Tybo, about 40 miles to the southeast, the Ordovician consists principally of limestone and is generally similar to the Eureka section, though in the northeastern part of the Roberts Mountain quadrangle, the western facies of Ordovician is thrust over the eastern. ${ }^{3 *}$

Permian sandstone, completely surrounded by Tertiary rocks, was found in place only in two small areas about a mile north of Manhattan and a half mile north of the nearest outcrop of Ordovician. These outcrops and the presence of a block of similar fossilferous Permian sandstone in the Tertiary rhyolite breccia overlying the Ordovician of Manhattan, suggest that here, as in the Candelaria Hills and the Toyabe Range, the Permian is unconformable on the Ordovician.

Granitic rocks, principally granodiorite, occupy large areas and cut the sediments irregularly. Dikes and sills of fine-grained white aplite are abundant along the planes of the pre-Tertiary faults and the bedding of the Ordovician slates.

\section{STRUCTURE}

In the southern area, including the Manhattan district, a number of parallel folds trend west and north-

${ }^{33}$ Ferguson, H. G., Geology and ore deposits of the Manhattan district, Nev. : U. S. Geol. Survey Bull. 723, 1924.

3erriam, C. W. and Anderson, C. A., Reconnaissance survey of the Roberts Mountains Ner.: Geol. Soc. America Bull., vol. 53, pp. 16751727. 1942. 
west and in part are overturned to the northeast. A narrow wedge of intensely folded Cambrian extends eastward from Manhattan and is thrust over the Ordovician on the north. Two miles east of Manhattan this thrust dips from $30^{\circ}$ to $40^{\circ} \mathrm{S}$., but steepens to $75^{\circ}$ near Manhattan and could not be traced west of the wash northwest of the town. The displacement is unknown. The southern border of the Cambrian is also a fault contact dipping to the south and southwest. It is possible that the thrust of Cambrian over Ordovician is cut off by this fault, which may itself be a thrust along the southern limb of an anticline.

Both the major faults are cut by many normal faults of small throw. These are in part at least of pre-Tertiary age, demonstrably so in places where small aplite dikes follow the fault planes. Most of these faults have a northeasterly strike and vertical to steep southeasterly dip. A few faults on the south limb of the anticline strike southeast. East of Manhattan later faults of larger throw and slightly different strike and dip displace the earlier faults. These are of Tertiary age as they are later than the mineralization, and faults of the same strike displace the lavas on the crest and western flank of the range north of Manhattan.

Southeast of the major anticline the folds in the Ordovician become more open, but the same general trend prevails; and there is a nearly parallel anticline in the southern part of the range.

Nothing definitely indicates the age of folding and thrusting in the Manhattan area except that it was prior to the granitic intrusions. The structures prevailingly trend eastward and are overturned northward, directions similar to these of the pre-Jurassic folds in the Pilot Mountains and Garfield Hills and to the prevailing trend of the Paleozoic rocks in the Miller Mountain area. These areas, however, are too far distant to warrant any inference based on similarity of structure.

\section{TOYABE RANGE}

The Toyabe Range (pls. 1, 15), of which the southern 40 miles enters the Tonopah quadrangle, is one of the highest and most prominent mountain ranges in the Basin and Range province. The highest point within the Tonopah quadrangle, Arc Dome, has an altitude of 11,775 feet, and the crest of the range exceeds 10,000 feet. On the east a steep scarp faces Big Smoky Valley; at the steepest part, the distance between the 11,000foot contour on the peak north of Broad Creek and the 6,000 -foot contour bordering the valley is a little less than 2 miles. The west flank of the range slopes irregularly toward the longitudinal valley which forms the boundary between the Toyabe Range and Shoshone Mountains. The present form of the range is chiefly the result of block faulting and tilting to the west.

The pre-Tertiary rocks of the Toyabe Range crop out along the entire east front in a belt from 1 to 5 miles wide, and also in an isolated area at the southern end of the range. Detailed study was confined to a small area near Jett Canyon (pl. 15).

\section{ROCKS EXPOSED}

Cambrian, Ordivician and Permian sedimentary rocks, Permian volcanic rocks, and intrusive rocks of probable Permian age are exposed in the area. These are cut by later granitic and phophyritic intrusives. The small area at the southern extremity of the range, underlain by the Dunlap and Luning formations, marks the eastern limit of the late Mesozoic sediments within the Tonopah quadrangle. (See p. 39.)

The Cambrian in the northern part of the range is probably several thousand feet thick. It consists largely of quartzite, slate, schist, and a few beds of white crystalline limestone. The Cambrian of the central part of the range is similar in character but contains less quartzite.

Ordovician rocks overlie the Cambrian conformably. In Jett Canyon the thickness does not greatly exceed 2,500 feet but is probably greater in other parts of the range. The Ordovician rocks are similar in character to those in the Toquima Range-principally slate, schist, and dark limestone in the lower part, and slate containing dark chert and a little interbedded limestone in the upper part.

The Permian is unconformable on the Ordovician. In places the unconformity is noticeably angular, elsewhere the attitude of rocks in the two systems is approximately accordant. The Permian is divided into two units, the lower almost entirely of sedimentary origin, the upper dominantly volcanic. The lower sedimentary division is more than 2,000 feet thick in the Jett Canyon region and consists dominantly of grit, conglomerate, and sandstone but contains rare lenses of limestone. In places near the base, lenses of coarse fanglomerate contain boulders derived from the Ordovician. Bedded tuff and rare lava flows, one showing pillow structure, occur in the lower unit but are not abundant. In the Jett Canyon area the upper part of the Permian is more than 4,000 feet thick and consists principally of volcanic material-greenstone and felsite flows and breccia, bedded tuff, and much chert-but also contains interbedded sandstone and grit similar to those in the lower part. A fine-grained felsitic rock, which generally shows flow banding, occupies large areas along the front of the range, particularly in the central and extreme southern parts. This rock is intruded into the flows and tuff of the upper part of the Permian and is cut by the granitic intrusives. The texture suggests that of the siliceous flows, but all the observed contacts show intrusive relations. Since rocks of this character were found only in the Toyabe Range where the volcanic Permian is of great thickness, the felsite is also likely to be of Permian age; for if associated with the 
Middle Triassic volcanism, the intrusive felsites should also occur in areas underlain by the Excelsior formation.

The Jurassic (?) intrusive rocks includes granodiorite and quartz monzonite, which intrude the sedimentary rocks irregularly, and large dikes of fine-grained granodiorite porphyry, following the planes of the large faults in the central part of the range.

\section{STRUCTURE}

The structural pattern of the range differs considerably from that of other ranges in that pre-Tertiary rocks are cut not only by thrusts but also by steep faults of large displacement. Some of these are interpreted as flaws, others are probably normal faults.

A northerly trend prevails in the northern part of the range and extends southward about 15 miles from the northern border of the quadrangle. The rocks generally dip steeply to the west and in places are overturned to the east. A reverse fault dipping about $60^{\circ}$ E. brings the Ordovician above the Permian in the northern part of the quadrangle, and extencls as far south as the granodiorite in Ophir Canyon (pl. 1) and the fault in the valley of North Twin River.

The fault that crops out in the valley of South Twin River likewise dips $60^{\circ}$ to $70^{\circ} \mathrm{E}$. Ordovician rocks form the hanging wall, and Permian greenstone and intrusive felsite the footwall. Granodiorite was intruded along the fault plane, and was sheared by later movement. Between these two faults is a westward striking steeply dipping fault that crops out in the valley of North Twin River. It is believed that the two northward-striking eastward-dipping faults are segments of a single major reverse fault on which movement was to the west, and that on the westward-striking fault movement was largely horizontal, with relative eastward movement of the southern block of about 2 miles.

A normal fault striking northeastward between South Twin River and the range front, may be of Tertiary age as it is nearly parallel to the frontal scarp and intrusive rocks were not observed along it. From this fault southward for about 6 miles, the pre-Tertiary rocks along the front of the range are Permian greenstone and intrusive felsite. This block is bordered on the south by another great fault, of northeasterly strike, along which a considerable mass of granodiorite has been intruded (pl. 1). The Jett Canyon fault (pl. 15), 3 miles farther south, also strikes northeast and dips $65^{\circ}-75^{\circ} \mathrm{NNW}$. The block between these two faults consists of Ordovician and unconformably overlying
Permian rocks apparently not highly folded. South of the Jett Canyon fault Cambrian and Ordovician rocks in the thrust slices are complexly folded (pl.15).

The Jett Canyon fault may be best interpreted as a flaw along which the northern block moved nearly 2 miles eastward. The fault separates areas in which the degree of folding differs, and drag is completely lacking in the thin-bedded Cambrian on the footwall side. Several normal faults of small displacement feather out from the Jett Canyon fault (pl. 15). These may be the result of adjustments during movement along the major fault, or may be connected with the intrusion of the granite porphyry along the fault plane.

South of the Jett Canyon fault, the rocks bordering the front of the range are cut by several thrusts, and the rocks in the thin slices are intensely folded. In places, as near the mouths of Jett and Pablo Canyons (pl. 15), the thrusts are cut parallel to the range front by normal faults of Tertiary or Pleistocene age. The lowest thrust brought Ordovician above Cambrian and is succeeded by another thrust that carried a second slice of Cambrian above the Ordovician (pl. 15), and the overlying Ordovician near the mouth of Pablo Creek is partly in thrust contact with the Cambrian of the upper block. Near the major thrusts, particularly in the block containing the Cambrian, the rocks are intensely folded and cut by several subordinate thrusts; but a short distance to the west the Ordovician and overlying Permian are only moderately folded.

The drag folds and the dip of the faults indicate a direction of movement between east and northeast. This accords with the interpretation of the Jett Canyon fault as a tear fault or flaw, and eastward movement must have been 2 miles or more. The Jett Canyon fault is post-Permian, but there is no direct evidence that these thrusts are a part of the Jurassic diastrophism. The westward movement indicated by the steep thrust in the northern part of the range, parallel to that of the Shoshone thrust in the Shoshone Mountains, 15 miles to the east, may be the result of impeded movement along a major eastward thrust broken by large transverse faults.

Later normal faults parallel to the range front cut the older structures and are believed to belong to the period of Tertiary and Quaternary faulting to which the range owes its present relief. Gravel scarps occur in some places, and the triangular interstream facets are well preserved. Near the southern end of the range a prominent cliff at the range front shows well preserved fault striae. 



\section{N D E X}

Page

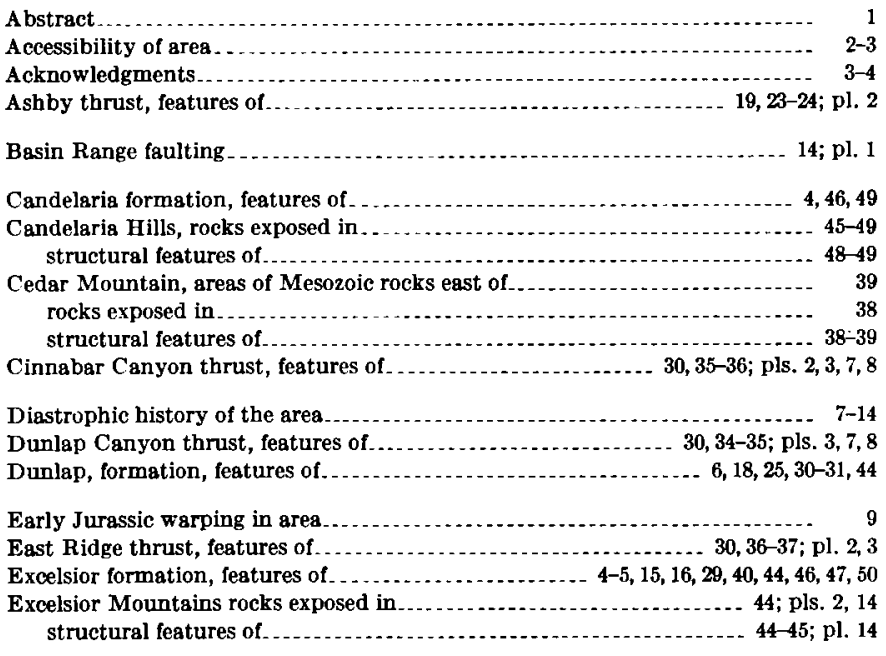

Field work.

Folding and thrusting, in the Luning Embayment localized.

$5,18,25,41 ;$ pl. 5

Gabbs formation, features of Gabbs Valley Range, rocks exposed in $\ldots \ldots \ldots \ldots \ldots \ldots \ldots \ldots \ldots \ldots \ldots \ldots$
structural features of. $\ldots \ldots \ldots \ldots \ldots \ldots$ Garfield Flat thrust, features of ........................ 20-23

Garfield Hills, early folding of Luning formation pre-Jurassic folding in

rocks exposed in . . ... structural features of ................. 19-25; pl. 2 Tertiary and Quaternary faults in

Gillis Range, rocks exposed in ............. 15-17

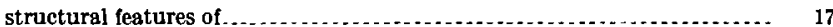
Tertiary normal faults in . . . . .

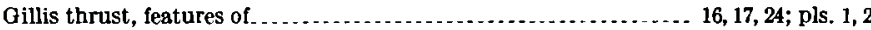
Granitic rocks, intrusion of

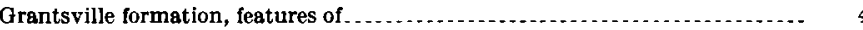

Intrusive rocks $6-7,13$

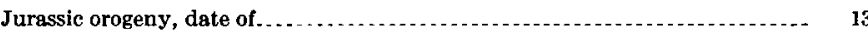

(13)

Jurassic system in the area, formations of

Location of area $. . . . . . . . . . . . . . . .1-2$

Lone Mountain, structural features of

Luning Embsyment, development of
Luning formation, features of

Page thrusts within

$5,17-18,25,29,40,41 ;$ pls. 1,2

MeGee thrust, features of Mac thrust, features of ......................................... 31-33; pls. 3, 7,8

Marble quarry thrust, features of . . . . . . . 23; pl. 2

Mesozoic rocks in area............. 4-7

Miller Mountain, rocks exposed in

structural features of

Monte Cristo Range, rocks exposed in

Monte Cristo thrust, features of

New York Canyon thrust, features of

$25-29 ;$ pls. 2,5

Northwest thrust, features of

$33-34$; pls. $3,7,8$

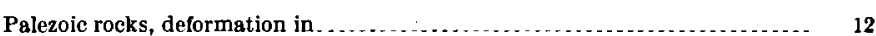
features of .........

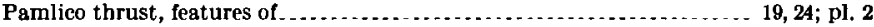

Paradise Range, rocks exposed in . . . . . . . . . . . . . . structural features of ................ 11

Pilot Mountains, normal faulting in . . . . . rocks exposed in structural features of . . . . . . . . . . . Post-Jurassic structure . .... . . . . Pre-Jurassic deformation........................

Pre-Permian folding ...................

Pre-Tertiary rocks, distribution of

Pre-Upper Triassic folding

Previous investigations

San Antonio Mountains, structural features of . . . . . . .

Shoshone Mountains, rocks exposed in........ 41 struetural features of . . . . . . .

Shoshone thrust, features of . .

Soda Spring Valley, flaw in ........... 14, 29

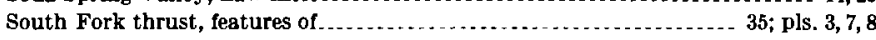

Spearmint thrust, features of $\ldots \ldots \ldots$.

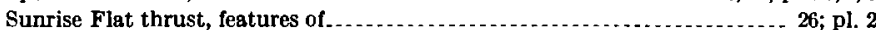

Sunrise formation, features of $\ldots$

Tertiary rocks in area, features of

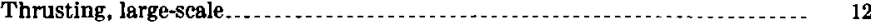

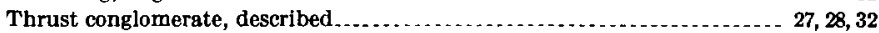

Toquima Range, rocks exposed in. . structural features of

Toyabe Range, rocks exposed in structural features of . . . . . $\ldots \ldots \ldots$

Triassic system in area, formations of

Unconformity, at base of Lower Triassic

at base of Middle Triassic........................................... 8

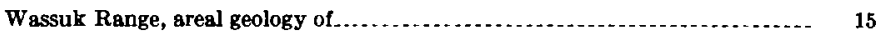

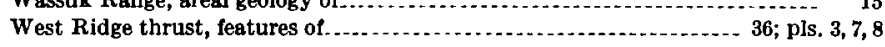







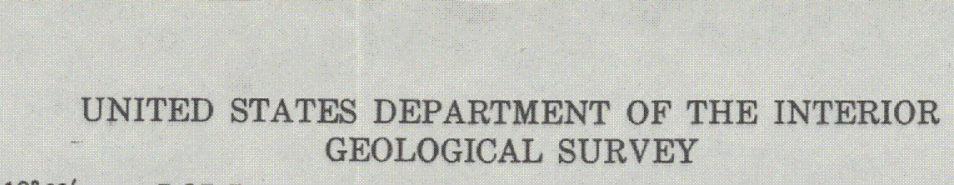

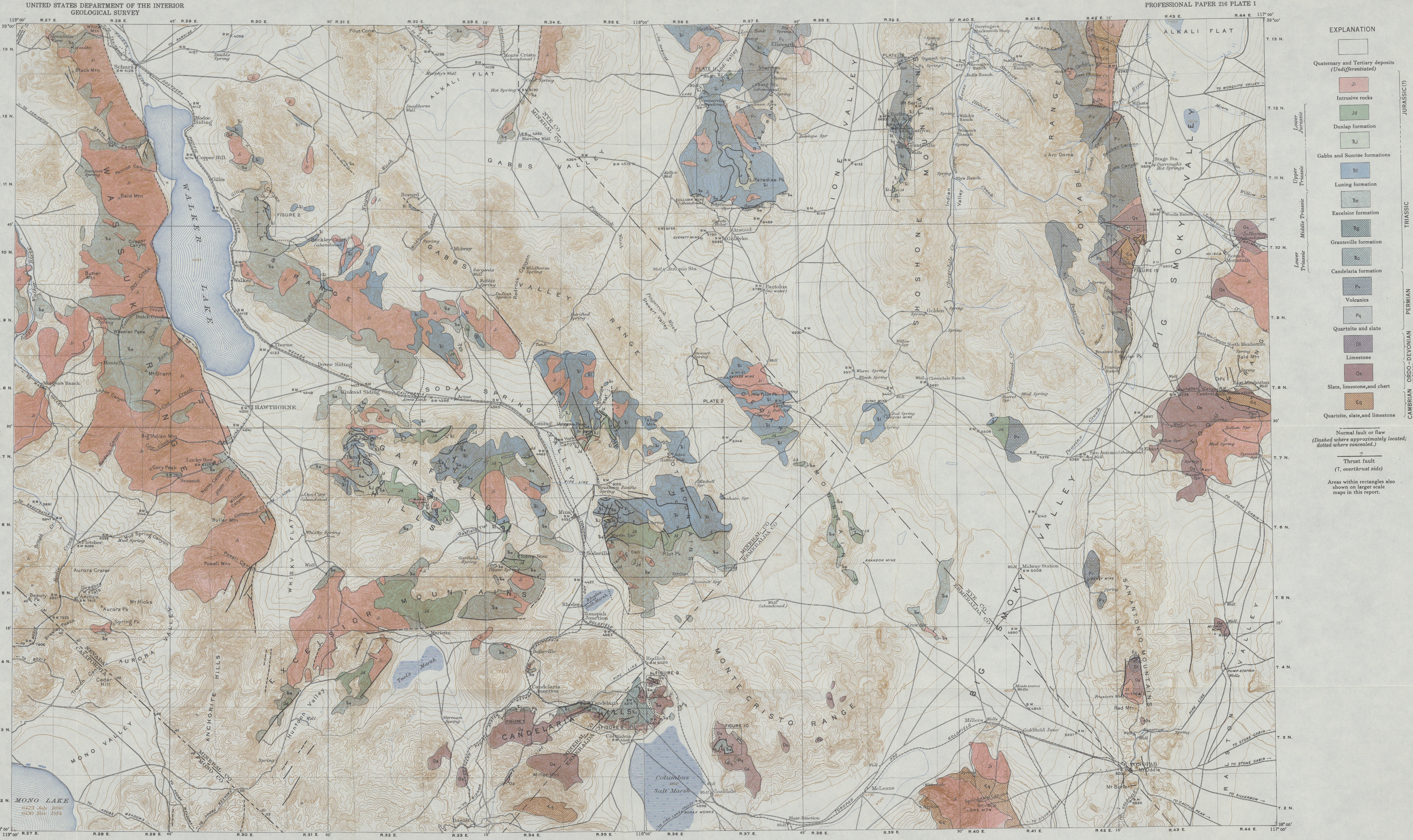

GEOLOGIC MAP OF HAWTHORNE AND TONOPAH QUADRANGLES, NEVADA, SHOWING DISTRIBUTION OF PRE-TERTIARY FORMATIONS

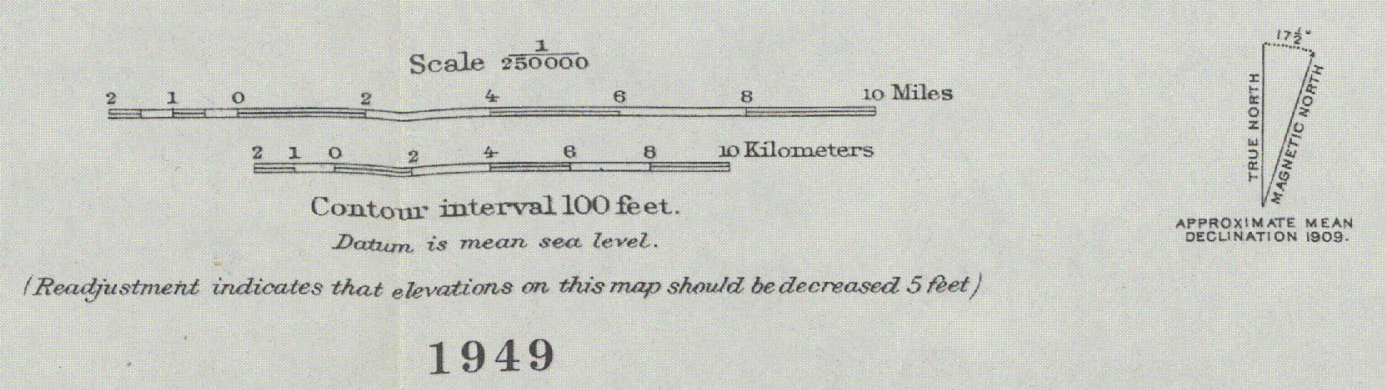




NNW.
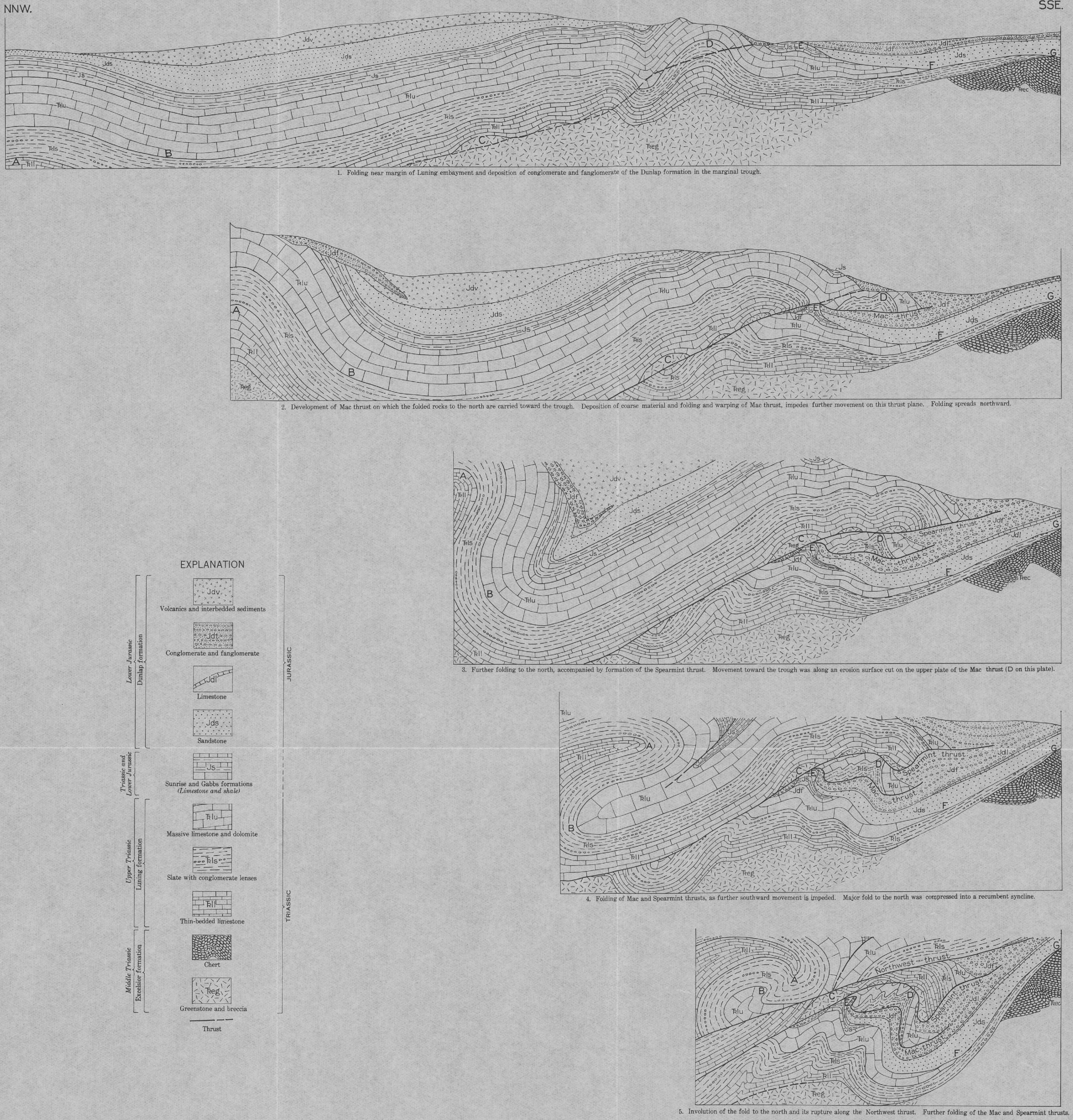

The sections are not drawn closely to scale but fol-

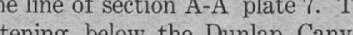
and South Fork thrusts is indicated by the

changing positions of the points A. B. C. D. E.

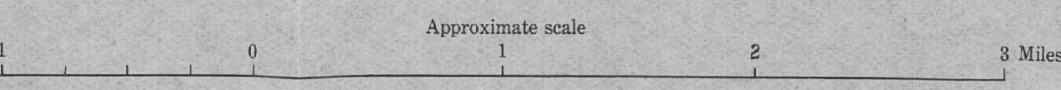

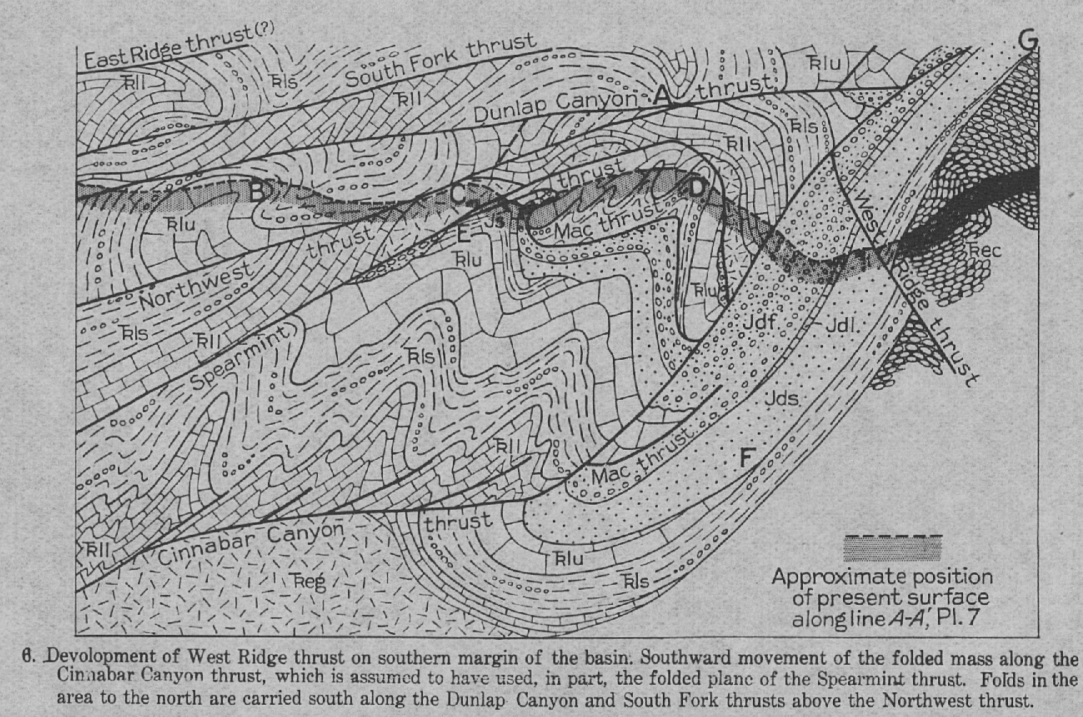




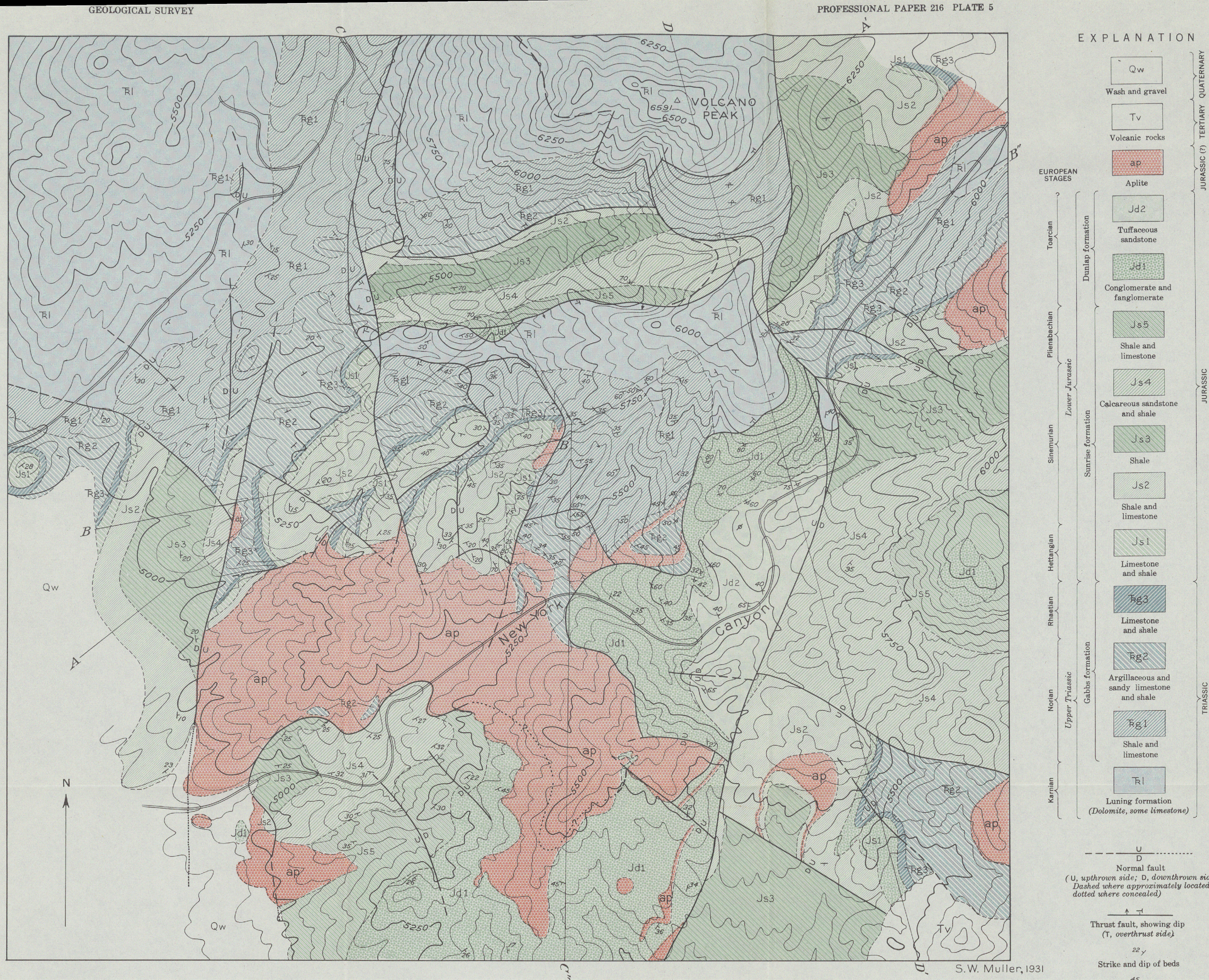

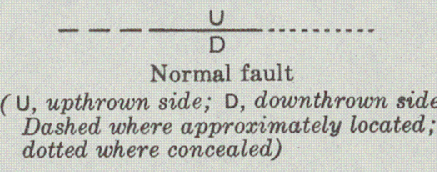

Thrust fault, hhowing dip
$(T$, overthrust side) Strike and dip of beds Strike and dip of
overturned beds

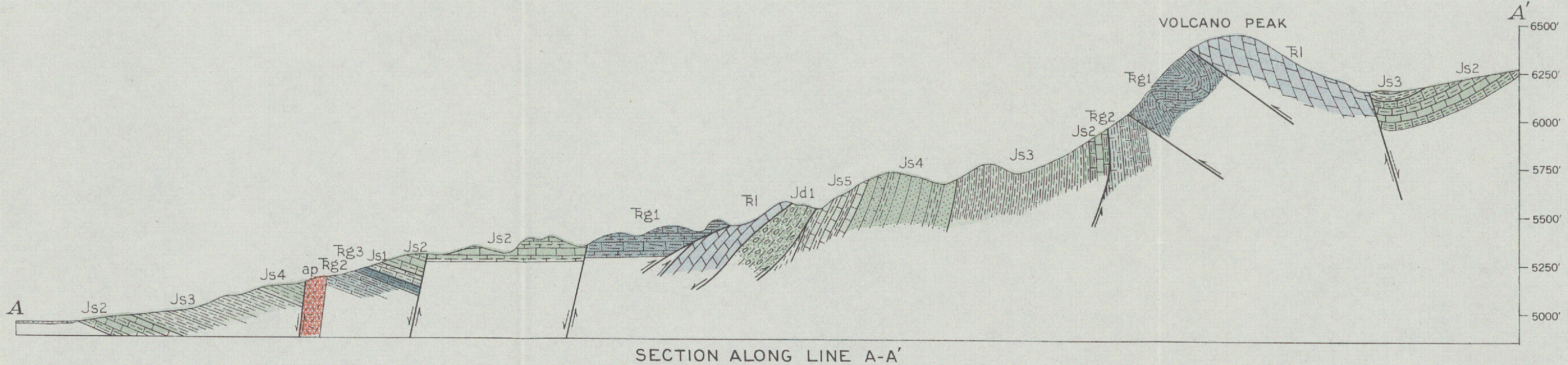

Strike of vertical beds
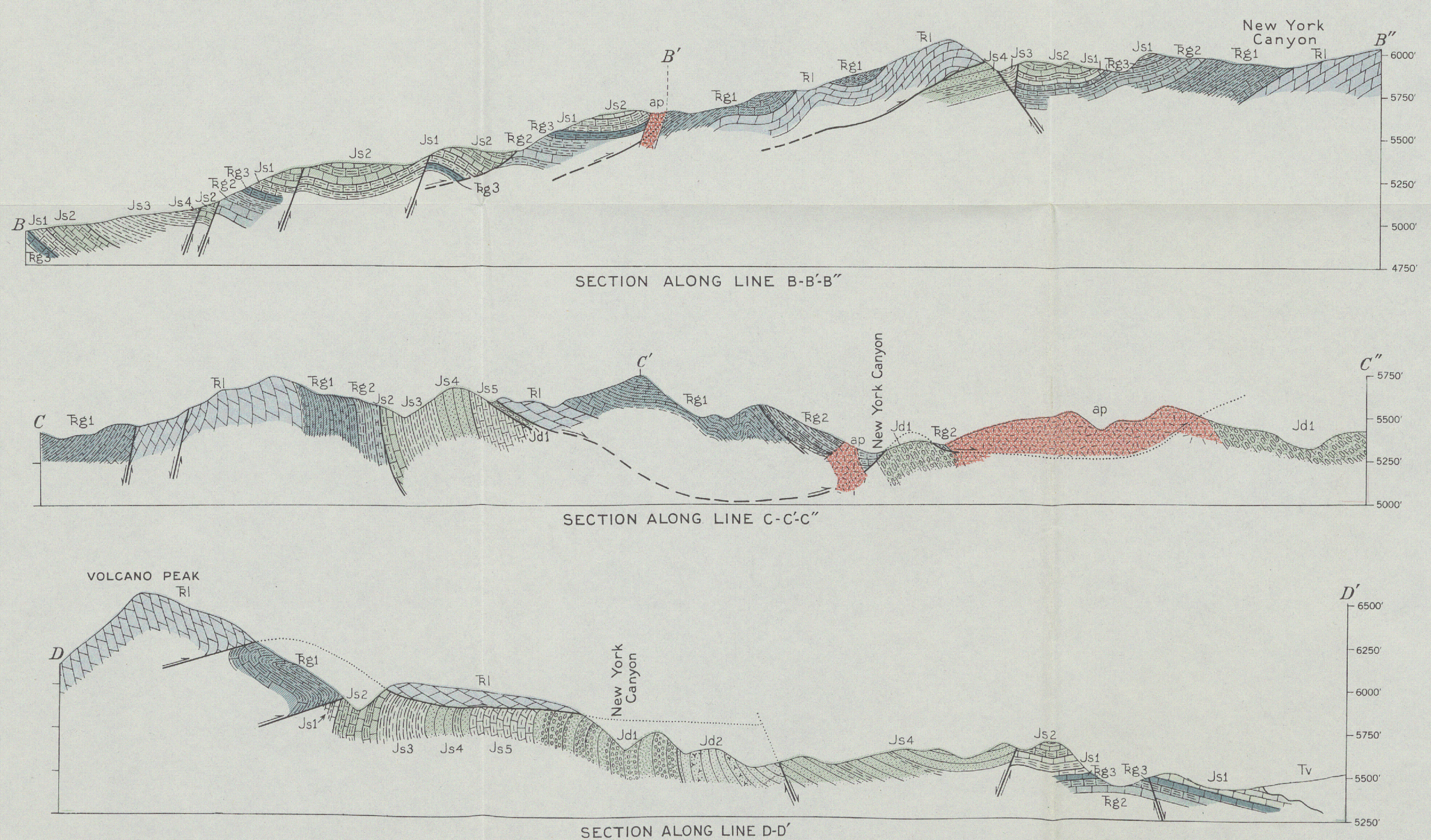

GEOLOGIC MAP AND SECTIONS OF AREA NEAR MOUTH OF NEW YORK CANYON, GABBS VALLEY RANGE, NEVADA

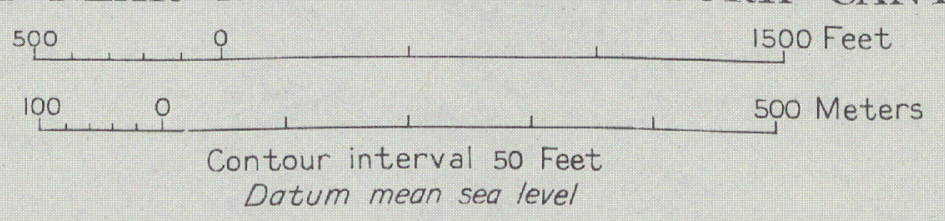




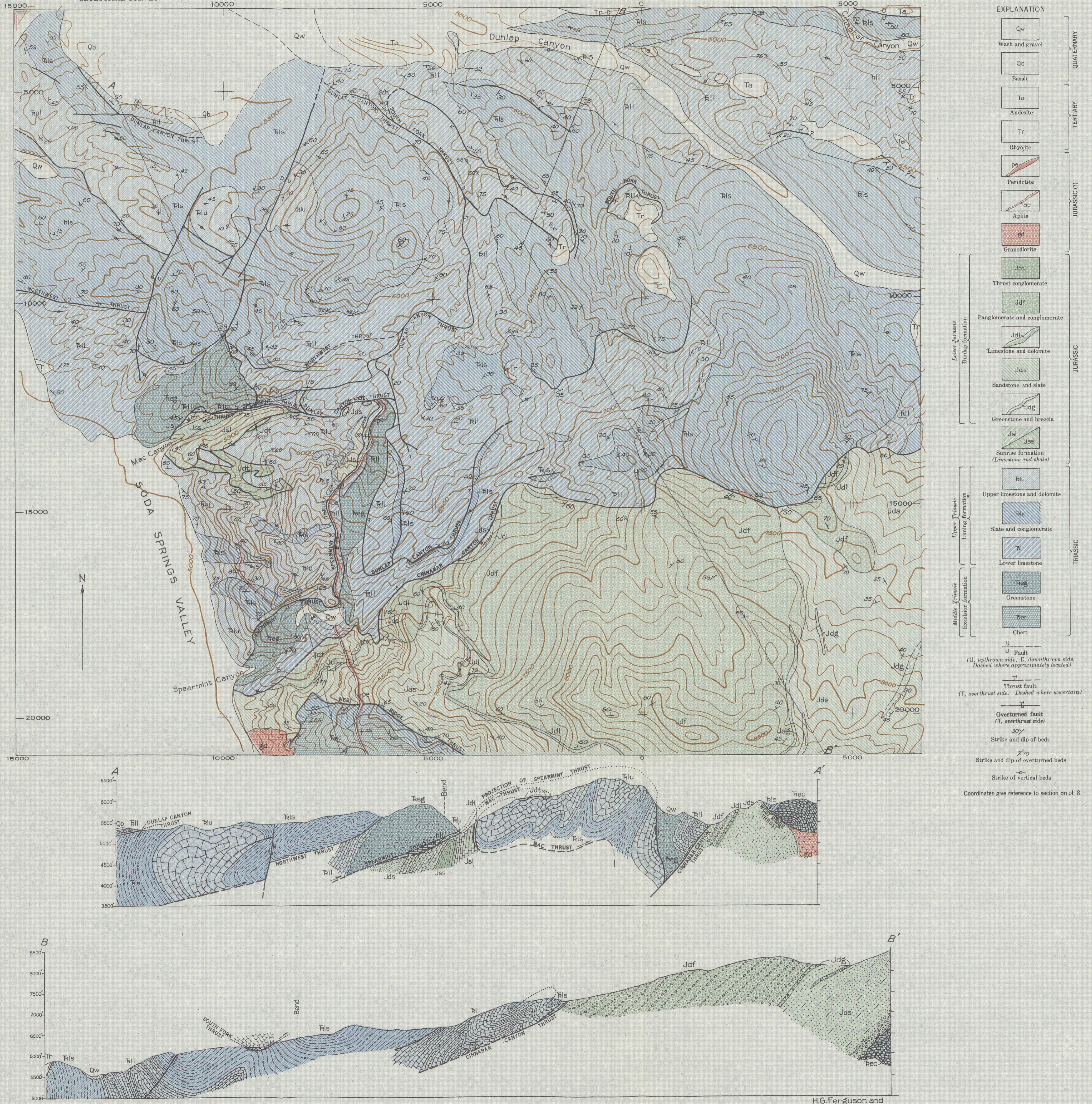

GEOLOGIC MAP ANI SEGTIONS OF NORTHWESTERN PART $\underset{1000}{\text { OF PILOT MOUNTAINS, NEVADA }}$ 


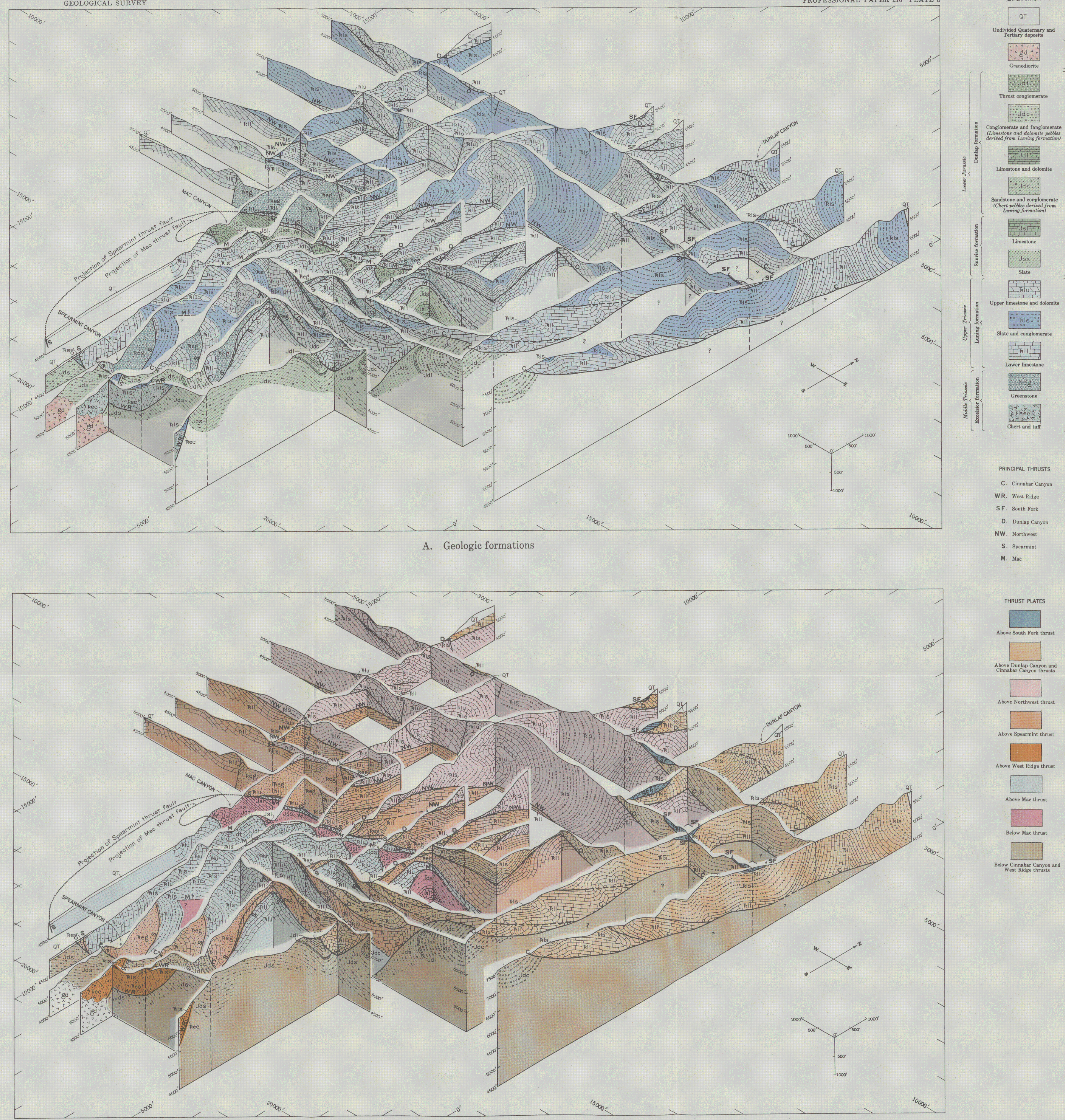

B. Same as A, Relations of thrust plates 


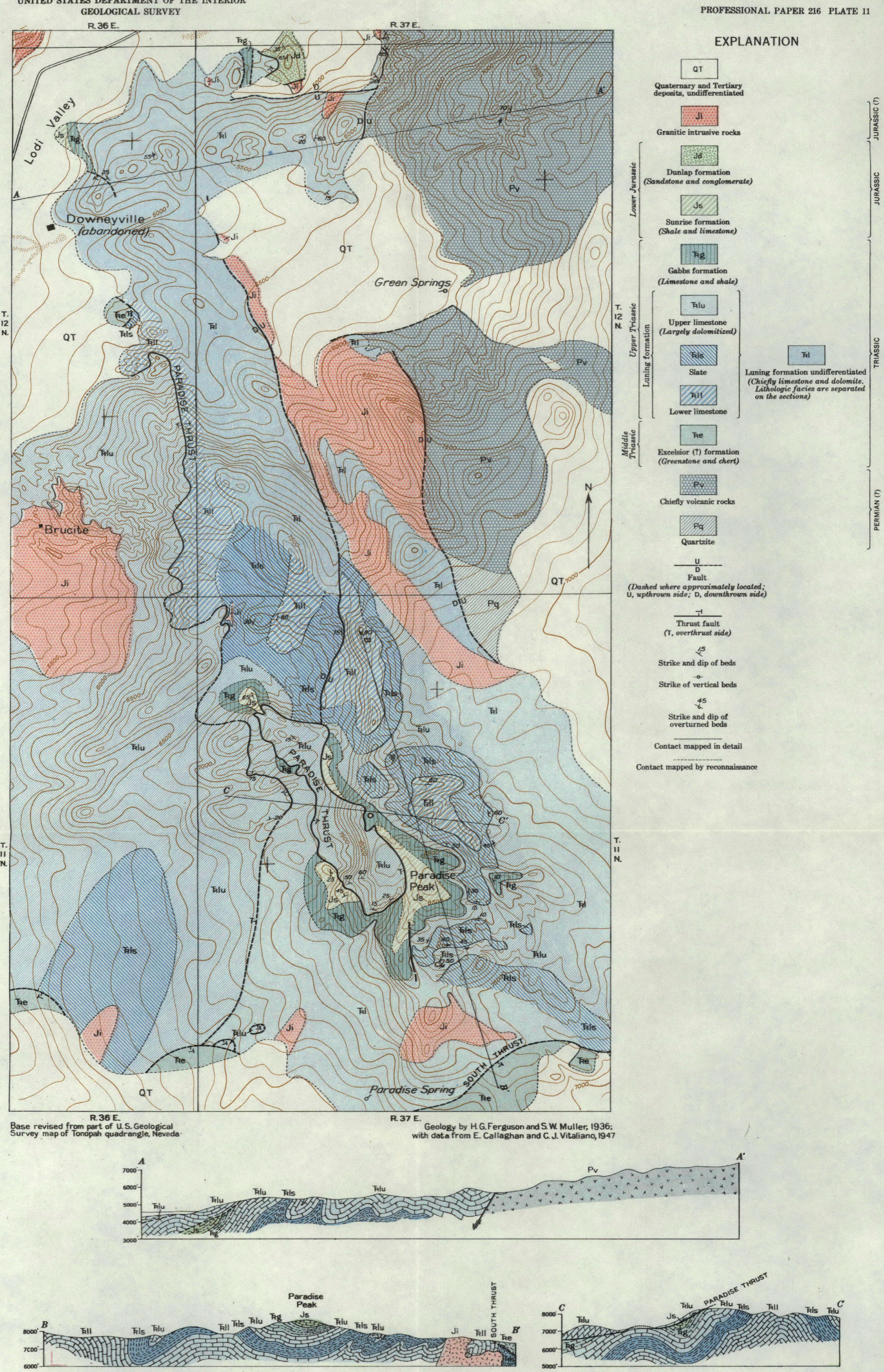

GEOLOGIC MAP AND SECTIONS OF PART OF PARADISE RANGE, NEVADA

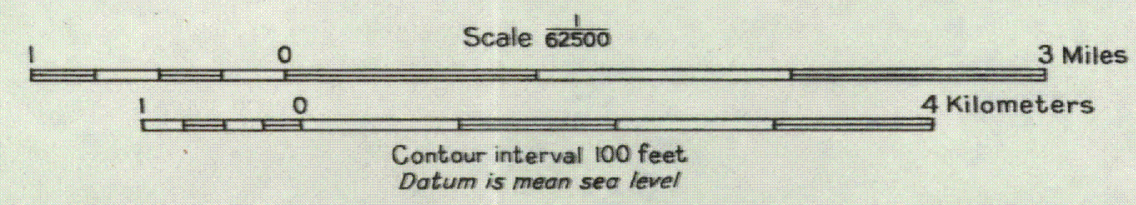





\section{UNITBD STATES DEPARTAENT OF THE INTERIO
GROLOCICAL SURVEY}
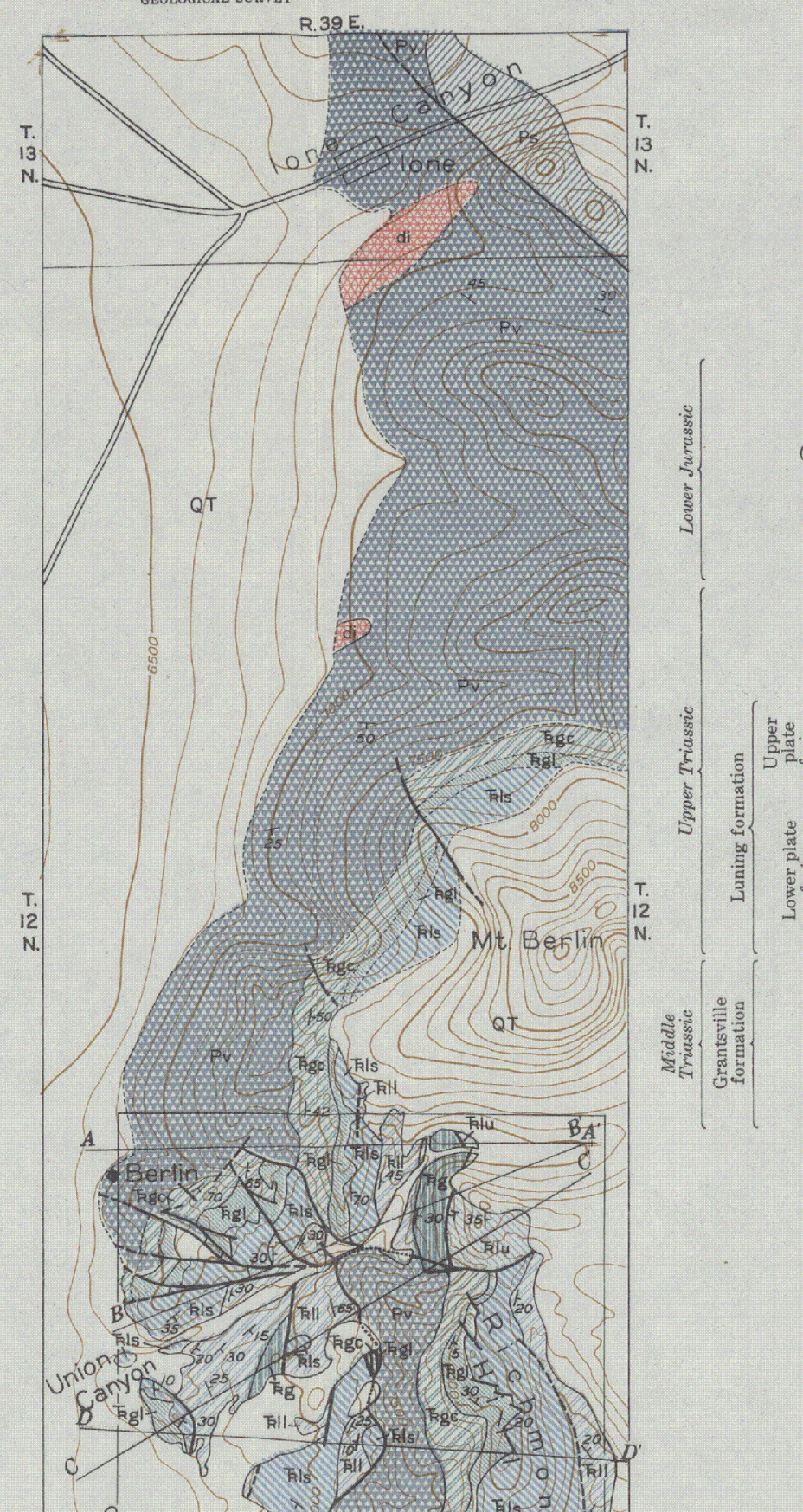

Gra

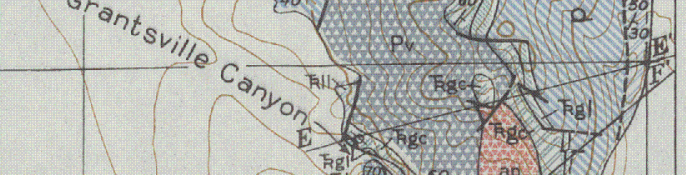

E

$+1$

30 (3) E. Grantsvit

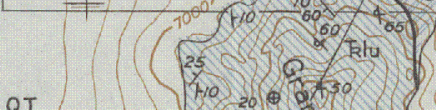

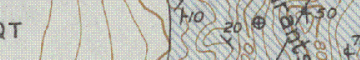

$(20,0.2$

kg

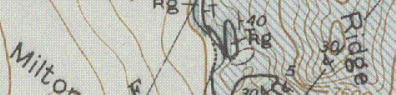

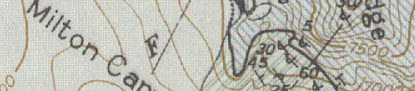

Ti.

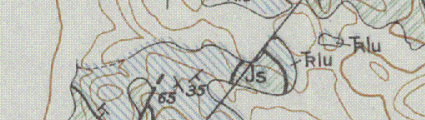

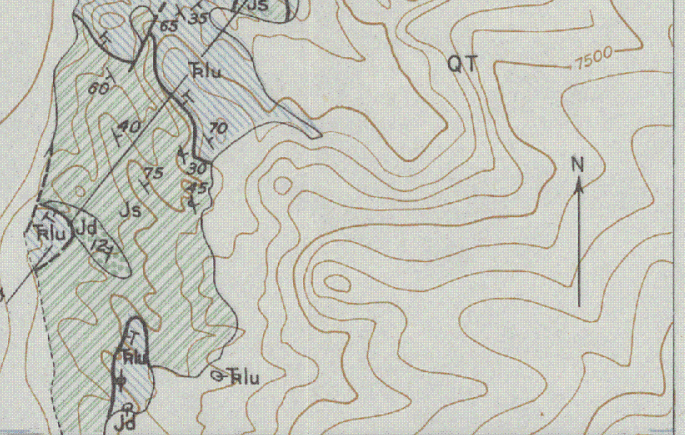

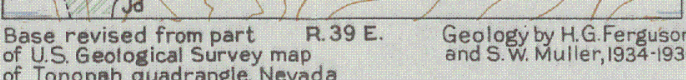

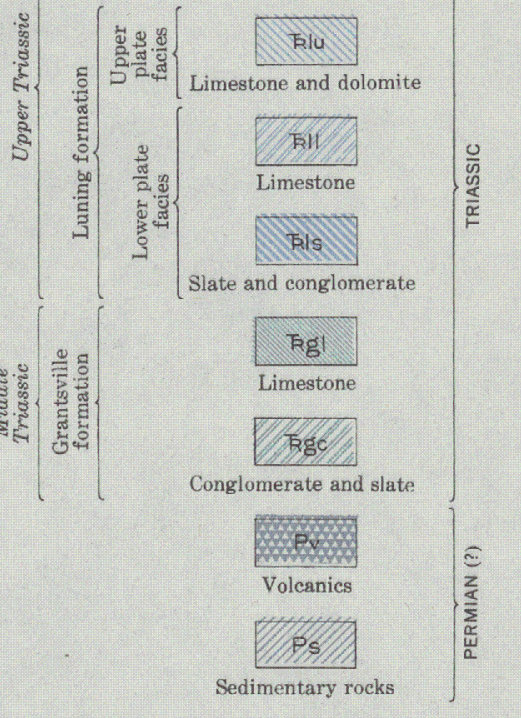

(Dashed where uncertai
dotted where concealed)

Strike and dip of beds

Strike of vertical beds

Horizontal beds

so
Strike and dip of
overturned beds

Contact mapped in deta
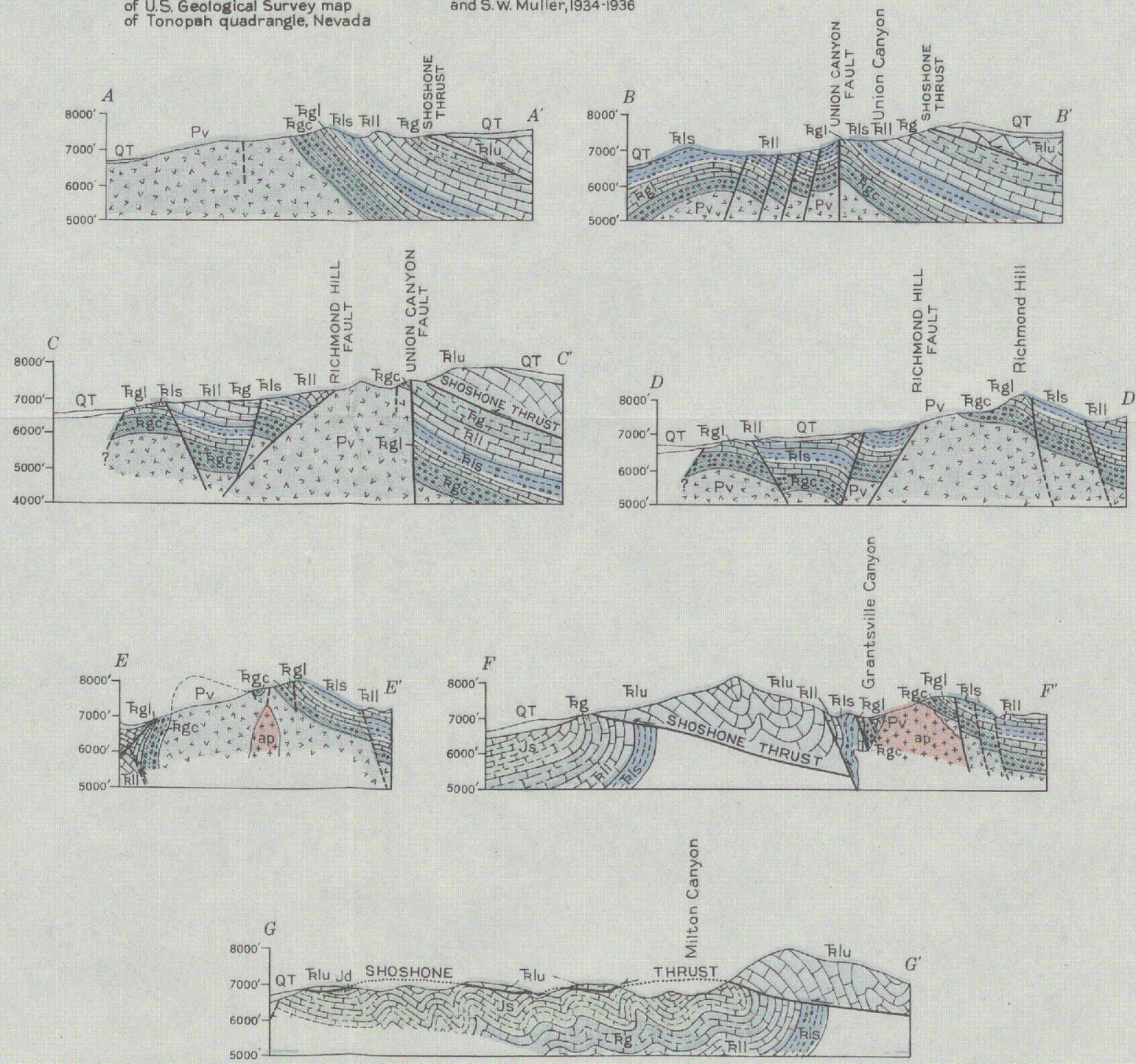

GEOLOGIC MAP AND SECTIONS OF PART OF SHOSHONE MOUNTAINS, NEVADA 


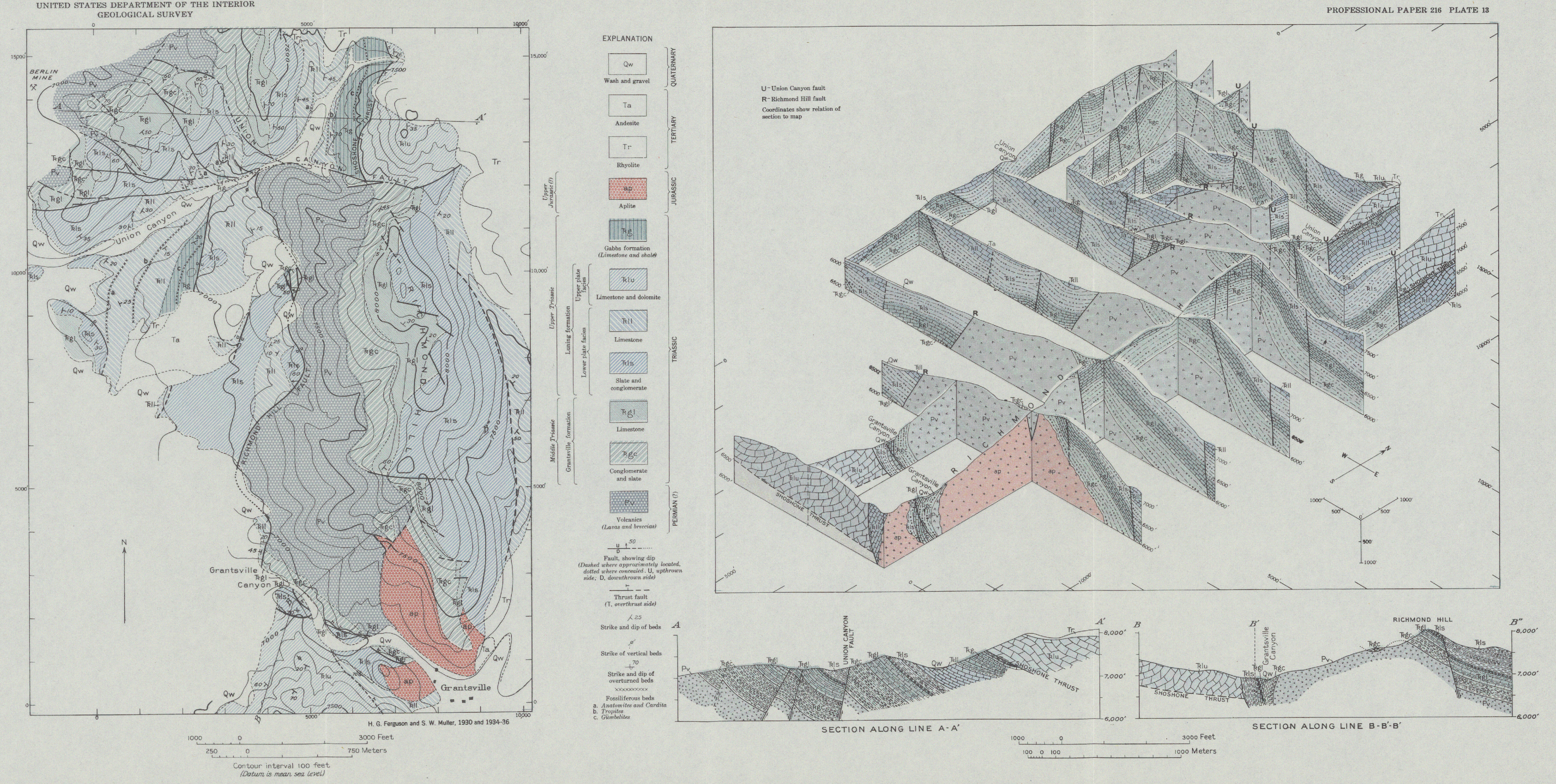



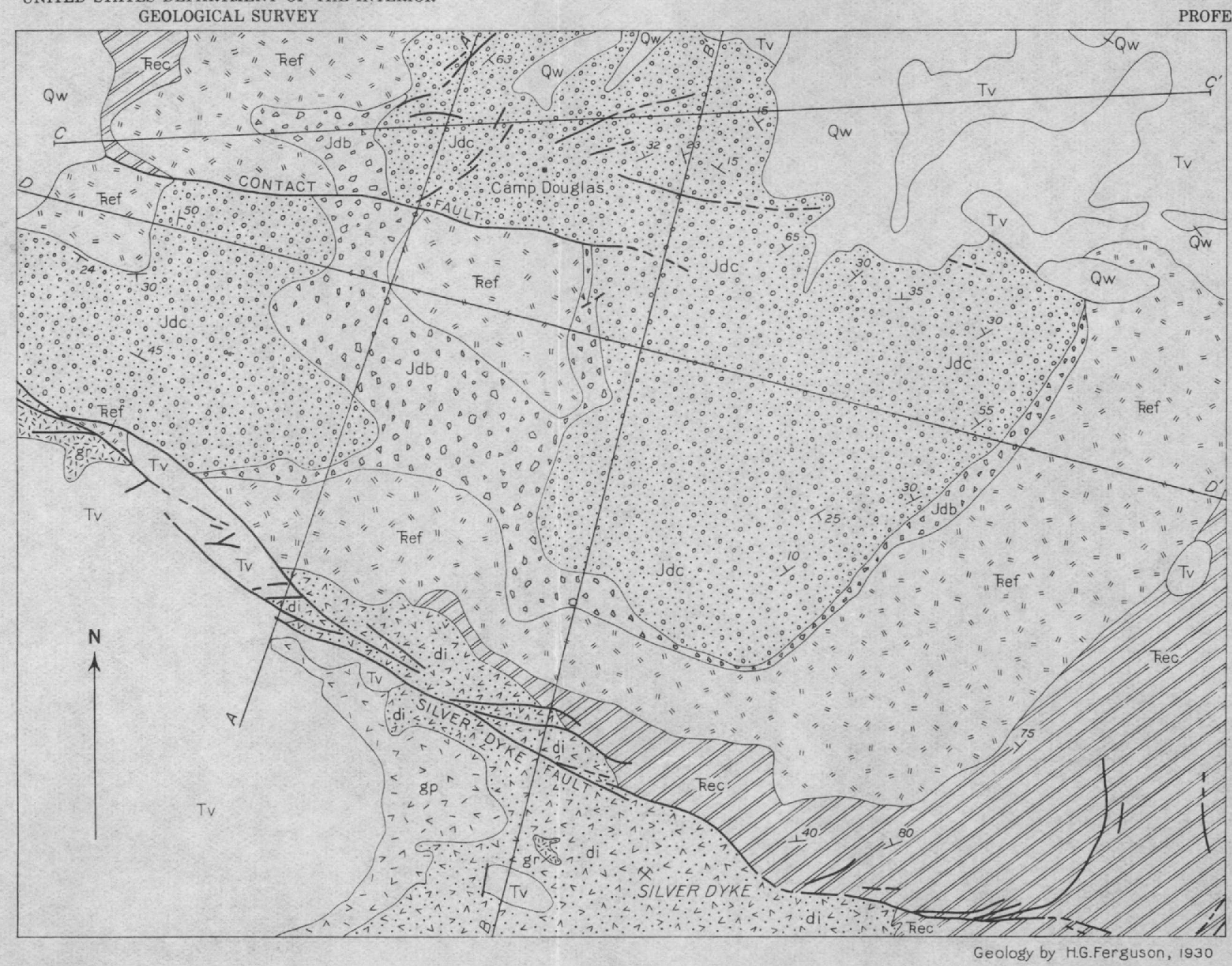

PROFESSIONAL PAPER 216 PLATE 14
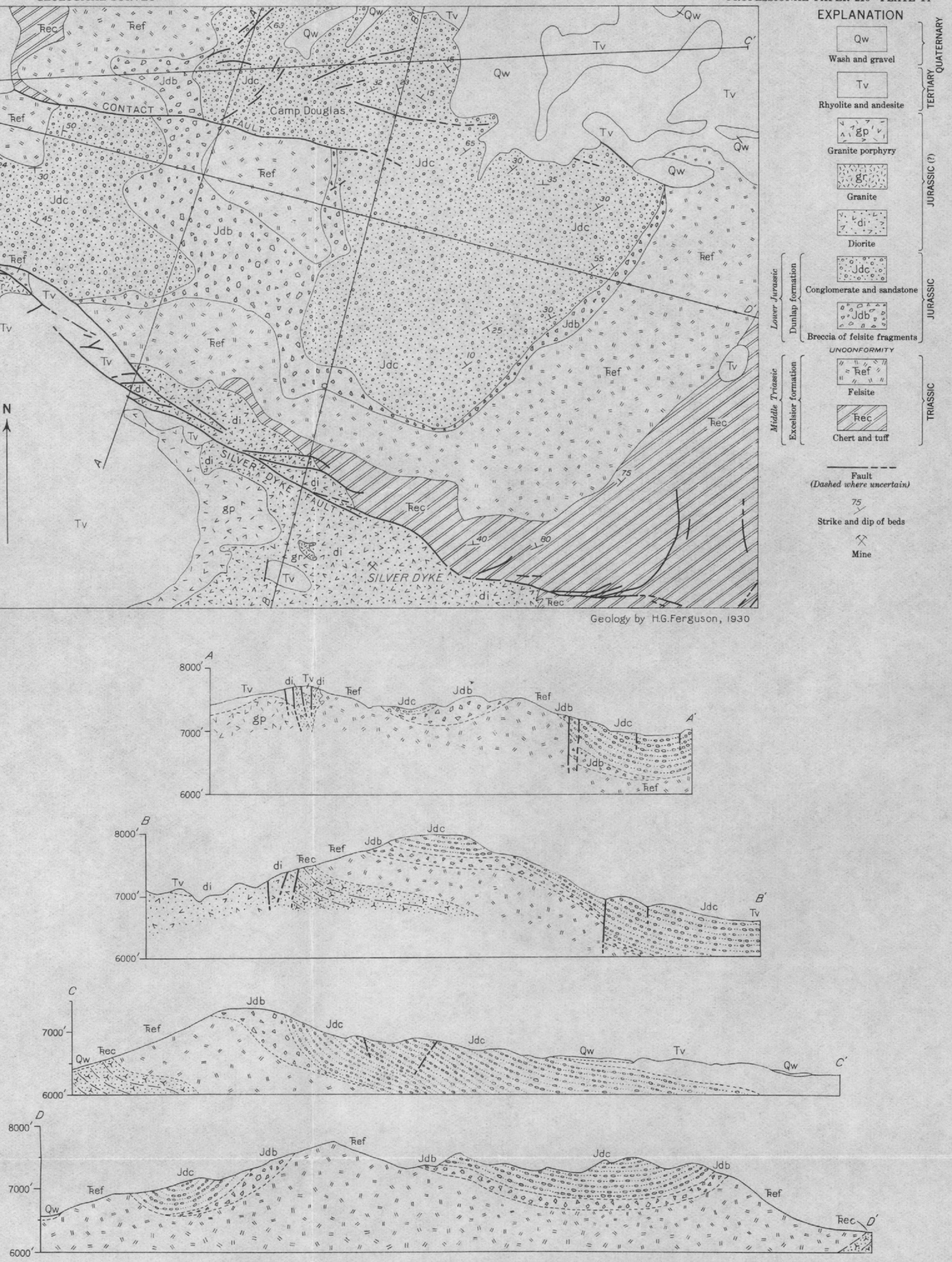

GEOLOGIC MAP AND SECTIONS OF PART OF THE GOLD RANGE DISTRICT, EXCELSIOR MOUNTAINS, NEVADA

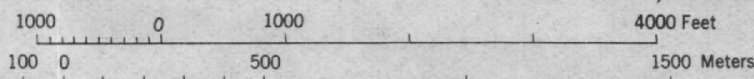




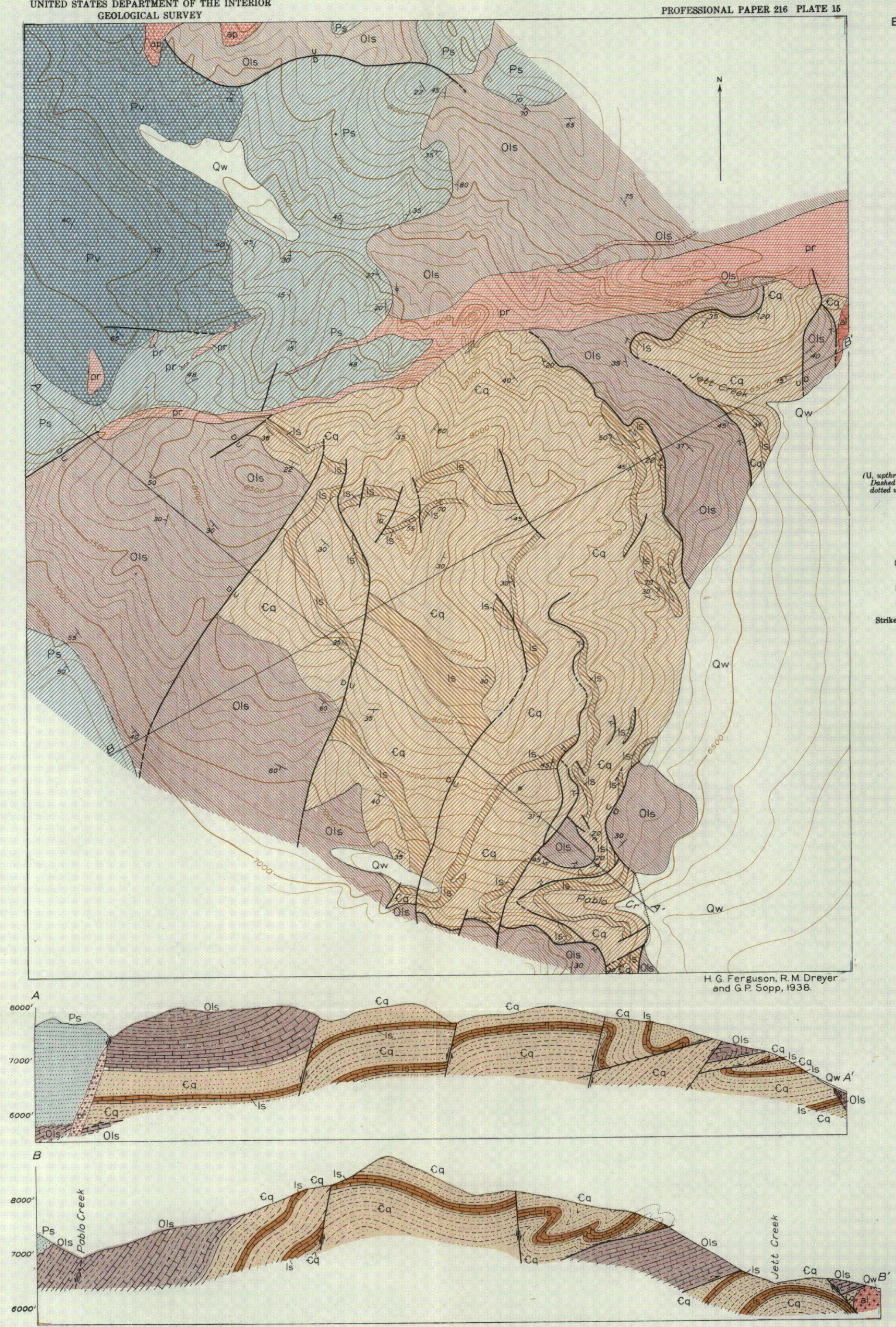

GEOLOGIC MAP AND SECTIONS BETWEEN JETT AND PABLO CANYONS, TOYABE RANGE, NEVADA

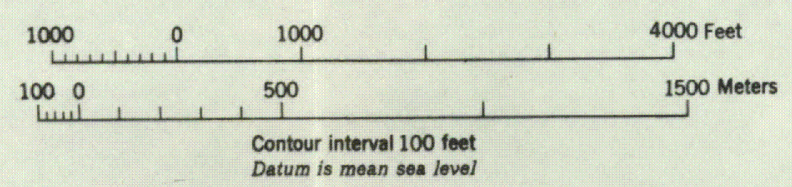


